
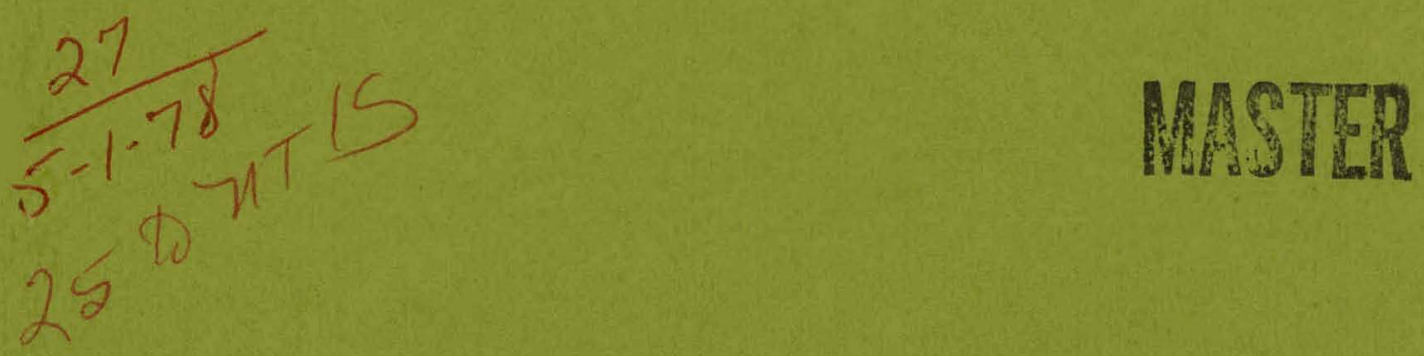

\title{
VALIDATION AND SOFTWARE DOCUMENTATION OF THE ANL FISH-IMPINGEMENT MODEL
}

\author{
by
}

Ishwar P. Murarka, Deborah J. Bodeau, and W. Kenneth Derickson

Prepared by

Division of Environmental Impact Studies

ARGONNE NATIONAL LABORATORY, ARGONNE, ILLINOIS

Prepared for the U. S. NUCLEAR REGULATORY COMMISSION under Contract W-31-109-Eng-38 


\section{DISCLAIMER}

This report was prepared as an account of work sponsored by an agency of the United States Government. Neither the United States Government nor any agency Thereof, nor any of their employees, makes any warranty, express or implied, or assumes any legal liability or responsibility for the accuracy, completeness, or usefulness of any information, apparatus, product, or process disclosed, or represents that its use would not infringe privately owned rights. Reference herein to any specific commercial product, process, or service by trade name, trademark, manufacturer, or otherwise does not necessarily constitute or imply its endorsement, recommendation, or favoring by the United States Government or any agency thereof. The views and opinions of authors expressed herein do not necessarily state or reflect those of the United States Government or any agency thereof. 


\section{DISCLAIMER}

Portions of this document may be illegible in electronic image products. Images are produced from the best available original document. 
The facilities of Argonne National Laboratory are owned by the United States Government. Under the terms of a contract (W-31-109-Eng-38) between the U. S. Department of Energy, Argonne Universities Association and The University of Chicago, the University employs the staff and operates the Laboratory in accordance with policies and programs formulated, approved and reviewed by the Association.

\title{
MEMBERS OF ARGONNE UNIVERSITIES ASSOCIATION
}

The University of Arizona Carnegie-Mellon University Case Western Reserve University The University of Chicago University of Cincinnati Illinois Institute of Technology University of Illinois Indiana University Iowa State University The University of Iowa
Kansas State University The University of Kansas Loyola University Marquette University Michigan State University The University of Michigan University of Minnesota University of Missouri Northwestern University University of Notre Dame
The Ohio State University

Ohio University

The Pennsylvania State University

Purdue University

Saint Louis University

Southern Illinois University

The University of Texas at Austin Washington University

Wayne State University

The University of Wisconsin

\section{NOTICE}

This report was prepared as an account of work sponsored by an agency of the United States Government. Neither the United States Government nor any agency thereof, nor any of their contractors, subcontractors, or any of their employees, makes any warranty, expressed or implied, or assumes any legal liability or responsibility for any third party's use, or the results of such use, of any information, apparatus, product or process disclosed in this report, or represents that its use by such third party would not infringe privately-owned rights.

The views expressed in this report are not necessarily those of the U. S. Nuclear Regulatory Commission.

\author{
Printed in the United States of America \\ Available from \\ National Technical Information Service \\ U. S. Department of Commerce \\ 5285 Port Royal Road \\ Springfield, Virginia 22161 \\ Price: Printed Copy $\$ 7: 25$; Microfiche $\$ 3.00$
}


ANL/ES-62

Environmental Research

$(\mathrm{NRC}-10)$

$$
044^{\circ 0^{\circ}}
$$

ARGONNE NATIONAL LABORATORY

9700 South Cass Avenue

Argonne, Illinois 60439

VALIDATION AND SOFTWARE DOCUMENTATION

OF THE ANL FISH-IMPINGEMENT MODEL

by

Ishwar P. Murarka, Deborah J. Bodeau, and W. Kenneth Derickson

Division of Environmental Impact Studies

4 NOTICE $\rightarrow$ MN ONLY

PORTIONS OF THIS REPORT ARE ILLEGIBLE. It has been roarolticed from the best available copy to permit the broadest possible availe : ability.

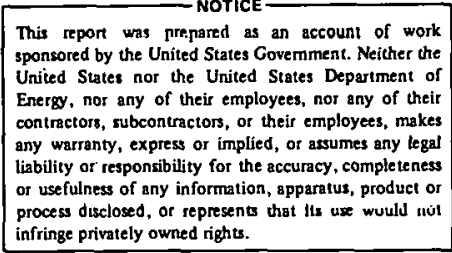

\footnotetext{
Prepared for the

Office of Nuclear Regulatory Research

U. - S. Nuclear Regulatory Commission under Contract W-31-109-Eng-38
} 
THIS PAGE

\section{WAS INTENTIONALLY LEFT BLANK}




\section{CONTENTS}

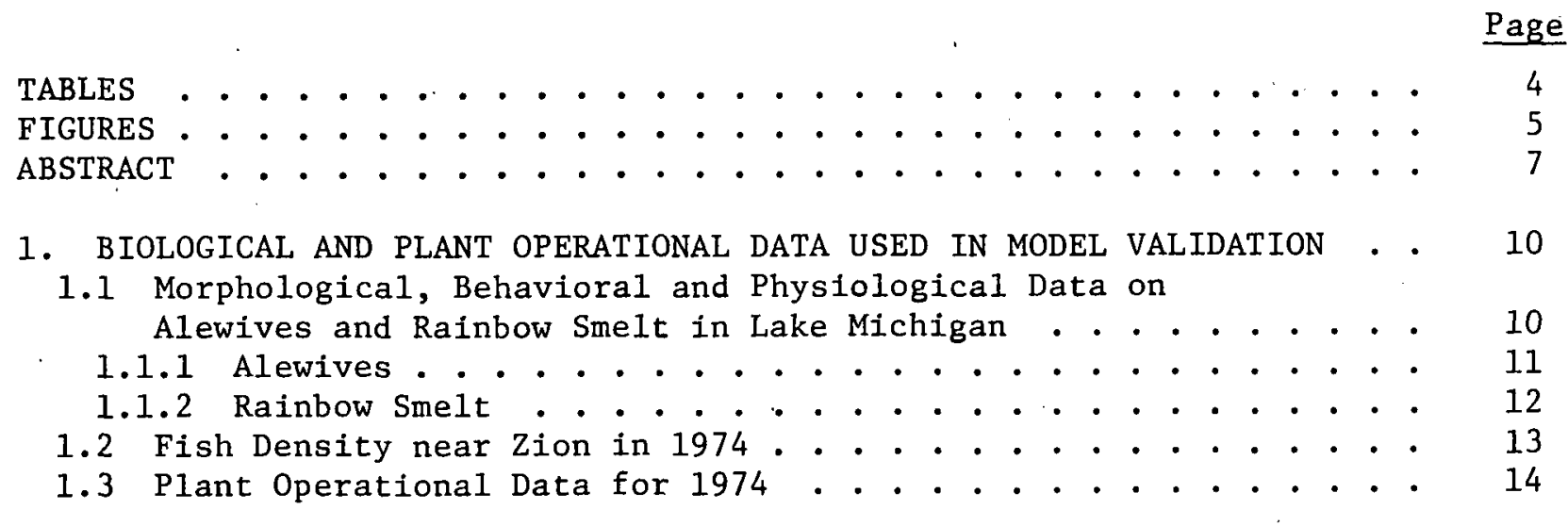

2. THE MATHEMATICAL MODEL . . . . . . . . . . . . . . . . 15

2.1 Modifications and Extensions of the Probability-Function

Component . . . . . . . . . . . . . . . . . . . 16

2.2 Modification of the Fish-Density Function . . . . . . . . . . . 18

2.3 Site- and Species-Specific Seasonal Correction Factors . . . . . 19

3. COMPUTED RESUlTS AND SENSITIVITY ANALYSES . . . . . . . . . . . . . 21

3.1 Case I for the Exponential Model . . . . . . . . . . . . . . 31

3.2 Case II for the Exponential Model . . . . . . . . . . . . . 34

3.3 Case III for the Exponential Model . . . . . . . . . . . . . 34

3.4 Comparison and Discussion of the Three Cases . . . . . . . . . . 86

4. DESCRIPTION AND DOCUMENTATION OF THE SOFTWARE SYSTEM . . . . . . . 87

4.1 Variables Used in COMMON Blocks . . . . . . . . . . . . . . . . 87

4.2 Main Program Simulate . . . . . . . . . . . . . . 89

4.2.1 Input to SIMULATE . . . . . . . . . . . . . . . . 89

4.2.2 Output Produced by SIMULATE . . . . . . . . . . . . 90

4.3 Subroutine VDLUME . . . . . . . . . . . . . . . . . 9 90

4.3.1 Input Required by VolUME . . . . . . . . . . . . . . . 91

4.3.2 Output Produced by VoluME . . . . . . . . . . . . . . 91

4.4 Subroutine NUMBER . . . . . . . . . . . . . . . . . . . 91

4.4.1 Input Required by NUMBER . . . . . . . . . . . . . . 91

4.4.2 Output Produced by NUMBER . . . . . . . . . . . . . 92

4.5 Subroutine OUTPUT .. . . . . . . . . . . . . . . . . 92

4.6 Subroutine IPLOT . . . . . . . . . . . . . . . . . 93

4.7 Subroutine SCATE. . . . . . . . . . . . . . . . . 94

4.8 Subprogram BLOCK data . . . . . . . . . . . . . . . . . 94

5. SUMMARY AND CONCLUSIONS . . . . . . . . . . . . . . . . . 119

Acknowledgments . . . . . . . . . . . . . . . . . . . 121

References . . . . . . . . . . . . . . . . . . 122 


\section{TABLES}

$\underline{\text { Table }}$

Page

1 Specification of Input Parameters to Define the Model

Form for Computing Daily Fish Impingements at Zion

Power Station in 1974 . . . . . . . . . . . . . . . 22

2. Input Data on Fish Catch and Length-Relative Frequency

Distribution for Trawl Days in 1974 . . . . . . . . . . 23

3 Observed and Interpolated Values of Daily Water-Volume

Pumped and Water Temperature in the Vicinity of the

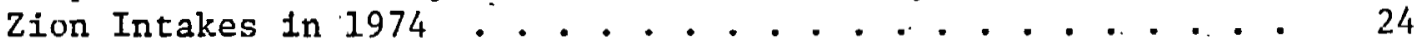

4 Daily Fish-Impingement Predictions Calculated According

to Case-I Specifications . . . . . . . . . . . . 35

5 Numerical Values for Fish Density and Probability of Impingement for Case I . . . . . . . . . . . . . 49

6 Daily Fish-Impingement Predictions Calculated According

to Case-II Specifications . . . . . . . . . . . . . 52

$7 \quad$ Numerical Values for Fish Density and Probability of Impingement for Case II . . . . . . . . . . . 65

8 Daily Fish-Impingement Predictions Calculated According to Case-III Specifications .. . . . . . . . . . 69

9 Numerical Values for Fish Density and Probability of Impingement for Case III . . . . . . . . . . . 83 


\section{FIGURES}

Figure

Page

1 Water Temperature at the Intakes of the Zion Station

2 Volume of Water Pumped through the Intakes of the Zion Station during 1974 . . . . . . . . . . . . . . . .

Alewife Fish Density in the Vicinity of the Intakes of the Zion Station during 1974 . . . . . . . . . . . . . .

4 Smelt Fish Density in the Vicinity of the Intakes of the Zion Station during 1974 . . . . . . . . . . . . . . . .

5 Predicted Impingement for Case I and Observed Impingement of Alewives at the Zion Station during 1974 . . . . . . 44

6 Predicted Impingement for Case I and Observed Impingement of Smelt at the Zion Station during 1974 . . . . . . . 45

7 Predicted Impingement for Case I and Observed Impingement of Both Species at the Zion Station during 1974 . . . . 46

8 The Risk of Impingement of Alewives According to the Probability Function under the Conditions of Case I . . . . .

9 The Risk of Impingement of Smelt According to the Probability Function under the Conditions of Case I . . . . .

10 Predicted Impingement for Case II and Observed Impingement of Alewives at the Zion Station during 1974 . . . . . .

11 Predicted Impingement for Case II and Observed Impingement of Smelt at the Zion Station during 1974 . . . . . . . .

12 Predicted Impingement for. Case II and Observed Impingement of Both Species at Zion Station during 1974 . . . . .

13 The Risk of Impingement of Alewives According to the Probability Function under the Conditions of Case II . . . . 64

14 The Risk of Impingement of Smelt According to the Probability Function under the Conditions of Case II . . . .

Predicted Impingement for Case III and Observed Impingement of Alewives at the Zion Station during 1974 . . . . . . 
FIGURES

Figure

Page

16 Predicted Impingement for Case III and Observed Impingement of Smelt at the Zion Station during 1974 . . . . . . . .

17 Predicted Impingement for Case III and Observed Impingement of Both Species at the Zion Station during 1974 . ...

The Risk of Impingement of Alewives According to the Probability Function under the Conditions of Case III. . . .

19 The Risk of Impingement of Smelt According to the

Probability Function under the Conditions of Case III .. . . . 
ABSTRACT

This report contains the results of a validation test of the ANL Fish Impingement Model. By the use of 1974 fish-impingement and environmental data from the $z$ ion Nuclear Power Station, it is shown that the modified and expanded mathematical model yields reasonably good results in calculations of daily fish-impingement losses at the cooling water intakes. Comparisons confirmed that the fish-impingement process depends primarily on the abundance of fish in the vicinity of a cooling water intake, whereas the probability function gives the susceptibility to impingement provided that fish are present in the "intensity region." In view of the limited amount of information available with regard to the various environmental and fish-abundance factors, it appears that the present form of the model is adequate and that efforts to refine the model further are not warranted. 
THIS PAGE

\section{WAS INTENTIONALLY LEFT BLANK}




\section{VALIDATION AND SOFTWARE DOCUMENTATION OF THE ANL FISH-IMPINGEMENT MODEL \\ Ishwar P. Murarka, Deborah J. Bodeau, and W. Kenneth Derickson}

Fish impingement occurs at almost all once-through cooling systems that draw water from rivers, lakes, and impoundments where fish reside. Often the numbers of fish killed by impingement at these cooling systems are obtained by sampling the intake screens for impingement losses. A mathematical model has been developed by Murarkal to obtain fish impingement values by the use of environmental and plant-related factors which define the fish-kill process at the intakes. The conceptual development included the formulation of mathematical functions that relate environmental factors, plant operational factors, and fish abundance in the vicinity of a cooling-water intake to fish impingement occurring at the intake. In this report we present the validation-test results to establish the reasonableness of the mathematical model.

Because data on many aspects of fish behavior are unavailable, our validation of the model is restricted to the mathematical form that can be used with available data. In this effort, we have used data from the Zion Nuclear Power Station located on Lake Michigan in Illinois. The 1974 fish-impingement data, together with the established information on fish behavior, plant water intake data, and fish distribution data, were used in validating the model. We modified parts of the formulation to increase the predictive capacity of the mathematical model and to incorporate the improved knowledge of the cause and effect relationships between the various environmental characteristics and the impingement process.

Efforts were made to acquire data from other electric power plants so that examples from several aquatic systems could be presented in support of the validated tests. Unfortunate we were not able to add more cases as examples, because the necessary data simply were not available. 


\section{BIOLOGICAL AND PLANT OPERATIONAL DATA USED IN MODEL VALIDATION}

An analysis of the 1974 impingement data from the Zion Nuclear Power Station indicated that alewives (Alosa pseudoharengus) and rainbow smelt (Osmems mordax) accounted for over $90 \%$ of the total numbers of impinged fish. ${ }^{2}, 3$ In order to determine why these species were so vulnerable to impingement, a literature search was made to assess the importance of their spatial distributions, seasonal abundances, size and growth rates, seasonal movements, swimming speeds and rheotactic behavior (attraction or adversion to currents) to the calculation of impingement rates. Ongoing studies ${ }^{4}$ have determined that abundance is plays an important factor; however, behavioral, morphological and physiological characteristics of these species may also contribute significantly to impingement rates. Certainly onshore migration and schooling would increase the chance of encountering cooling water intake currents. Once a group of these fish is exposed to an intake current their small body size, a positive rheotactic response, coupled with slow swimming speed, will interact to enhance the chance of entrapment and impingement of many individuals.

These biological data were incorporated into the model along with plantrelated data on ambient water temperatures, intake pumping rates, and approach velocities. Calculated impingement rates were compared with observed rates; then data were modified or deleted if they did not add to the accuracy of the model. The final model contains only those biological factors that contribute significantly to its predictive ability.

\subsection{MORPHOLOGICAL, BEHAVIORAL AND PHYSIOLOGICAL DATA ON ALEWIVES AND} RAINBOW SMELT IN LAKE MICHIGAN

Size and swimming speeds, calculated from data in the literature, were incorporated into the expanded probability function discussed in Section 2. Data on schooling, seasonal movement, and rheotactic response were not really quantifiable, but were assumed to be implicit within the density function. 


\subsubsection{Alewives}

Alewives are the most abundant species in Lake Michigan, comprising about $80 \%$ of the total fish biomass. ${ }^{5}$ In the Zion area, individuals average about: $167 \mathrm{~mm}$ long with a maximum length of $215 \mathrm{~mm} .{ }^{6}$ Alewife larvae are about $3.5 \mathrm{~mm}$ at hatching and reach a maximum length of $119 \mathrm{~mm}$ by the end of their first year. Growth rates are highest during the first year (ca. $115 \mathrm{~mm}$ ), declining considerably in succeeding years $(45,22,17$ and $14 \mathrm{~mm}$ in the second, third, fourth and fifth years, respectively). 6 These growth rates were used to generate the formula (Eq. 1),

$$
L=118.6 \times x^{0.383}
$$

where $L$ is the total body length in $\mathrm{mm}$ and $\mathrm{X}$ is the age in years or fractions thereof. This formula was used to calculate monthly mean lengths for a maturing population of fish. These sizes were then incorporated into the expanded probability function, with the maximum length set at $162 \mathrm{~mm}$ since most of the impinged alewives were less than two years of age. 7

Data on swimming speeds are from studies made by Colby ${ }^{8}$ and Kothas. ${ }^{9}$ These studies provided sustained swimming speeds $(\mathrm{cm} / \mathrm{sec})$ at different temperatures for fish 61-104 mm long, and such data were used to generate the formula (Eq. 2),

$$
\mathrm{S}=1.608 \mathrm{~T}+0.116 \mathrm{~L}
$$

where $\mathrm{S}$ is sustained swimming speed in $\mathrm{cm} / \mathrm{sec}, \mathrm{T}$ is the temperature in ${ }^{\circ} \mathrm{C}$, and $\mathrm{L}$ is the total body length in $\mathrm{mm}$. This formula was used to calculate mean monthly sustained swimming speeds for different sized fish at different temperatures for the expanded probability function. The maximum swimming speed for this function was based on the monthly mean maximum temperature for fish $162 \mathrm{~mm}$ long.

Information on seasonal movements by alewives indicates that adults (ageclass II and older) remain in the deeper offshore waters, ${ }^{10}$ except during 
spring and summer months when they move into the shallower inshore waters to spawn. ${ }^{2,6}$ Young-of-the-year and yearlings remain in the shallow waters until October, then migrate to deeper offshore waters. ${ }^{2}, 6,11$

Schooling and a positive rheotactic response have been observed in this species. Romberg et al. ${ }^{12}$ and Emery ${ }^{13}$ have observed large schools of alewives congregating at outfalls. In their study of thermal effluents, Romberg et ai., ${ }^{12}$ concluded that the alewives were attracted to the discharge's strong current rather than its temperature. Richkus ${ }^{14,15}$ also observed and experimentally demonstrated that alewives exhibit a positive rheotactic response.

From the above information on the morphological, behavioral and physiological characteristics of the fish, it is easy to see why alewives are so vulnerable to impingement. A large portion of the population--those fish less than two years old (162 $\mathrm{mm}$ in length)--spend most of the spring and summer months schooling in shallow waters where the power plant intakes are located, thereby increasing the likelihood of being exposed to intake currents.

\subsubsection{Rainbow Sme1t}

Rainbow smelt are slightly smaller than alewives in this portion of Lake Michigan. The adults average $157 \mathrm{~mm}$ and reach a maximum length of $221 \mathrm{~mm} .^{6}$ The larvae are about $5 \mathrm{~mm}$ long at birth ${ }^{7}$ and reach a length of $106 \mathrm{~mm}$ by the end of their first year. Their growth rates are highest during the first year (ca. $100 \mathrm{~mm}$ ) and remain fairly constant, though somewhat lower, during succeeding years $(35,30$ and $40 \mathrm{~mm}$ in the second, third and fourth years, respectively). 6 These growth rates were used to generate the relationship (Eq. 3)

$$
L=117.7 \times \mathrm{X}^{0.345}
$$

where $\mathrm{L}$ is the total body length in $\mathrm{mm}$ and $\mathrm{X}$ is the years or fractions thereof. Lengths were generated and incorporated as described in Section 1.1.1. The maximum size for the probability function was $141 \mathrm{~mm}$ since most of the impinged smelt were less than two years old.7 
The data on swimming speed were less comprehensive than those for alewives. Industrial Bio-Test Laboratories, Inc. 16 tested fish averaging $134 \mathrm{~mm}$ in length at $5^{\circ}$ and $15^{\circ} \mathrm{C}$ to ascertain their maximum sustained swimming speeds. These data, after some modification were used to calculate the relationship (Eq. 4)

$$
\mathrm{S}=25.85 \times \mathrm{T}^{0.169}
$$

where $\mathrm{S}$ is the maximum sustained swimming speed in $\mathrm{cm} / \mathrm{sec}$ and $\mathrm{T}$ is the temperature in ${ }^{\circ} \mathrm{C}$. In order to compensate for the lack of data on swimming speed as a function of body size, the maximum observed swimming speed $(41 \mathrm{~cm} / \mathrm{sec})$ was used as the maximum value in the expanded probability function for all months.

Data on seasonal movements of rainbow smelt indicated that adults tend to remain in offshore waters most of the year, only coming inshore to spawn during spring. The young-of-the-year and yearlings are found in the shallower inshore waters during most of the year, moving offshore to cooler waters from June to August only. $5,10,17$

Schooling and a negative rheotactic response have been observed in this species. Romberg et $a .^{8}$ and Emery ${ }^{9}$ saw large schools of rainbow smelt during their studies. Romberg et al. ${ }^{8}$ also noted that this species congregated outside the thermal plume area and tended to avoid higher water velocities.

From these data, it is not readily apparent why young-of-the-year and yearlings are so vulnerable to impingement. While their schooling habits and tendency to remain inshore increases their chances of encountering intake currents, the negative rheotactic response should help counteract the danger. However, once entrapped, impingement is inevitable because of this species' small size and, hence, slow swimming speeds.

\subsection{FISH DENSITY NEAR ZION IN 1974}

Mean densities of alewife and rainbow smelt were computed for each of the days when trawl-catch data were available. Abundance was computed for the 
two species from trawl collections taken in 1974 at the 5.5-m depth contour near the Zion intake structure. ${ }^{2,3}$ After consultation with several fishery biologists, the trawl was assumed to be only $20 \%$ efficient and all densities were adjusted accordingly.

\subsection{PLANT OPERATIONAL DATA FOR 1974}

Average daily pumping rates (cfs) and ambient water temperatures were taken from 1974 Zion Station Operational Monitoring Reports. ${ }^{2,3}$ Yearly maximum and minimum temperatures were used as inputs to the model. We calculated the approach velocities on the basis of the intake pipeline velocities. The intake structure is a crypt with a velocity cap about $254 \mathrm{~cm}$ below the water surface. The velocity past this cap is generally less than $25 \mathrm{~cm} / \mathrm{ser}$; hnwever, fish can easily enter the crypt and once inside they are exposed to the higher velocities of the intake pipes. At maximum pumping rates (3990 cfs) intake velocities in the pipelines are $265 \mathrm{~cm} / \mathrm{sec}$ and $\mathrm{fish}$ that come too close to the openings of the intake pipes will become entrapped and eventually impinged after entering the intake forebay area. We established Equation 5 below to relate approach velocities to water pumping rates by using data from the NALCO Environmental Sciences' studies: ${ }^{7}$

$$
A=0.066 \mathrm{P},
$$

where $A$ is the approach velocity in $\mathrm{cm} / \mathrm{sec}$ and $P$ is the pumping rate in cfs. 
2. THE MATHEMATICAL MODEL

The basic form of the model as formulated by Murarkal is given in Equation 6 ,

$$
\dot{I}(t)=\sum_{i=1}^{k} P_{i}(t) \times Q(t) \times D_{i}(t),
$$

where $\quad \dot{I}(t)=$ the total fish impingement rate at time $t$ for all species of fish (usually a daily rate),

$\mathrm{P}_{i}(t)=$ the probability that an individual fish of species $i$ is impinged on the screen at time $t$, given that the fish is present in a defined "zone of influence" or "intensity region",

$Q(t)=$ the volume of the water entering the intake per unit of time at time $t$, and

$D_{i}(t)=$ the number of fish of species $i$ in a unit volume of water in the zone of influence at time $t$.

In Equation 6, $Q(t)$ and $D_{i}(t)$ are measured quantities at known points in time. $Q(t)$ is normally calculated on the basis of the design capacity of the water pumps and the hours of use of the pumps during a given day. $D_{i}(t)$ is calculated from catch obtained by means of fishing gear suitable for sampling fish abundance. We used data obtained by trawling at a depth of 5.5 meters in the water column. The catch data were converted to number of fish per thousand cubic feet per day and were also adjusted for the gear efficiency.

The $P_{i}(t)$ function was formulated as given in Equation 7.1 Then we made changes to expand and modify the form of Equation 7 as discussed in Section. 2.1. 


$$
P_{i}(t)=\left(\frac{T(t)-T_{\min }}{T_{\max }-T_{\min }}\right)\left(\frac{A(t)-A_{\min }}{A_{\max }-A_{\min }}\right)\left(\frac{S_{i}(t)-S_{\min }}{S_{\max _{i}-S_{\min }}}\right)\left(I-\frac{L_{i}(t)}{L_{\max _{i}}}\right) .
$$

where

$$
\begin{aligned}
& T(t) \text { is water temperature at time } t \text {, } \\
& A(t) \text { is water approach velocity at time } t \text {, } \\
& S_{i}(t) \text { is swimming speed of the fish of } i^{\text {th }} \text { species at time } t \text {, and } \\
& L_{i}(t) \text { is length of the fish of } i^{\text {th }} \text { species at time } t \text {. }
\end{aligned}
$$

The ranges of the variables are:

$$
\begin{aligned}
& \mathrm{T}_{\min } \leq \mathrm{T}(\mathrm{t}) \leq \mathrm{T}_{\max }, \quad \mathrm{A}_{\min } \leq \mathrm{A}(\mathrm{t}) \leq \mathrm{A}_{\max } \\
& \mathrm{S}_{\min } \leq \mathrm{S}_{i}(\mathrm{t}) \leq \mathrm{S}_{\max _{i}}, \quad \quad \mathrm{~L}_{\min } \leq \mathrm{L}_{i}(\mathrm{t}) \leq \mathrm{L}_{\max _{i}} \text {. }
\end{aligned}
$$

\subsection{MODIFICATIONS AND EXTENSIONS OF THE PROBABILITY-FUNCTION COMPONENT}

As we progressed with the model validation work we found that there were some aspects of the formulation in Equation 2 that needed change. Since temperature, length, and swimming speed are heavily correlated, we felt that the length and temperature variables were the most important in the model consideration, therefore we eliminated $\mathrm{S}$ from the Equation 7 . Pumping rate is strongly correlated with approach velocity and was considered to be more important to the model, thus $A$ was also eliminated from Equation 7. Another reason for eliminating these two variables was that values for $A$ and $S$ were derived from very few data points and as a result introduced large errors into the model, thereby reducing its predictive ability: By assuming that the remaining two factors in Equation 7 are independent in affecting the probability of impingement for the $i^{\text {th }}$ species at time $t$, we obtained the modified version shown as Equation 8. For Equation 8, we expanded the mathematical formulation using the length, L, variable. We divided the fish lengths into a maximum of six classes. From the trawl-catch data, we would know the shortest (beginning) and longest (ending) lengths of the fish in each of the 
six classes. The relative frequency, $f_{i, j}(t)$, for each length class for each species of fish were also available from the catch data. This bivariate approach utilizing the length-class distribution and the conditional probability of impingement given the length class provides a better representation of the time-dependent fish-impingement process as it relates to fish lengths. The fish-length classes could be further increased to provide a higher degree of resolution in calculating the $P_{i}(t)$ values. However, the success of such changes would depend entirely on the availability of the relative frequency distribution data for the additional class intervals.

Thus the modifled form of the probability function is the following:

$$
\begin{aligned}
P_{i}(t) & =\left(\frac{T(t)-T_{\min }}{T_{\max }-T_{\min }}\right)+\left[\sum_{j=1}^{N_{i}} f_{i, j}(t)\left(\frac{L_{e, i, j}-L_{b, i, j}}{L_{\max _{i}}-L_{\min }}\right)\right] \\
& -\left(\frac{T(t)-T_{\min }}{T_{\max }-T_{\min }}\right)\left[\sum _ { j = 1 } ^ { N _ { i } } f _ { i , j } ( t ) \left(\frac{L_{e, i, j}-L_{b, i, j}}{\left.\left.L_{\max _{i}-L_{\min _{i}}}\right)\right]}\right.\right.
\end{aligned}
$$

where $\quad L_{e, i, j}$ is the fish length for end of the $j \frac{\text { th }}{\text { length class }}$ of the $i \frac{\text { th }}{}$ species,

$L_{b, i, j}$ is the fish length for beginning of the $j \frac{t h}{2}$ length class.. of the $i \frac{\text { th }}{\text { species, }}$

$\mathrm{F}_{i, j}$ is the relative frequency of fish of species $i$ belonging

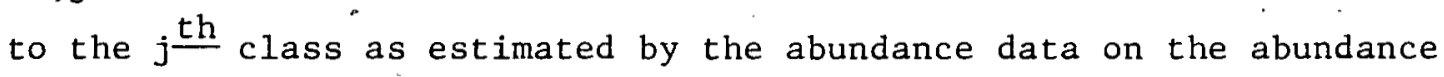
in the vicinity of the cooling water intakes, and

$N_{i}$ is the number of length classes (not to exceed 6) for the $i^{\text {th }}$ species. 


\subsection{MODIFICATION OF THE FISH-DENSITY FUNCTION}

In the basic form of the model (Eq. 6) we presented the function $D_{i}(t)$ as the time-dependent, species-specific fish density function near the water intakes. For the case when $D_{i}(t)$ was not actually observed for each of the time elements during the year, the function was expanded to include interpolated values for the daily fish densities. In validating our model on days when trawls were not made, we used a linear interpolation between successive observations to generate the fish-density values.

We provide the two alternative forms of the function $D_{i}(t)$. The linear formulation is Equation 9 ,

$$
D_{i}(t)=d_{i}(L),
$$

where $d_{i}(t)$ is the fish density of $i^{\text {th }}$ species given in terms of numbers per thousand cubic feet of water per 24-hour period: It is calculated from traw1catch data by means of Equation 11 :

The exponential formulation for $D_{i}(t)$ is given in Equation 10 .

$$
D_{\perp}(t)=\exp \left[\lambda_{\perp} \times d_{1}(t)\right]
$$

where $d_{i}(t)$ is the fish density per thousand cubic feet per day observed or interpolated for the $i^{\text {th }}$ species, and $\lambda_{i}$ is the species-specific transfer coefficient.

The $d_{i}(t)$ value includes the correction for gear efficiency. Since trawl data were used to represent fish density for the Zion case, we have used $20 \%$ as the catch efficiency of the gear and, therefore, obtained the $d_{1}(t)$ from Equation 11,

$$
d_{i}(t)=\frac{c_{i} \times 86.4}{w_{g} \times D_{g} \times v_{g} \times t_{g} \times e_{g}},
$$


where $\quad C_{i}=$ number of fish of $i \frac{\text { th }}{}$ species in the trawl catch,

$\mathrm{W}_{\mathrm{g}}=$ width. (in feet) of the trawling gear,

$\mathrm{D}_{g}=$ diameter of the trawling gear opening,

$\mathrm{V}_{\mathrm{g}}=$ velocity with which the gear was towed,

$t_{g}=$ time duration (in seconds) of the trawl, and

$e_{g}=$ efficiency of the trawl gear.

In Equation 11 the value 86.4 is the conversion coefficient for obtaining fish density per thousand cubic feet of water per day.

\subsection{SITE- AND SPECIES-SPECIFIC SEASONAL CORRECTION FACTORS}

On further examination of the model, we found that the mathematical representation needed to be expanded to allow for site-specific and speciesspecific seasonal correction factors. Therefore, we included a term $M_{i}(t)$ in the model as a site- and species-specific seasonal correction factor, i.e., simply a constant multiplier for a given season for the $i \frac{\text { th }}{}$ species.

Combining all these modifications and rewriting the complete mathematical form of the fish-impingement model we get Equation 12 as expansion of Equation 6 and of Equation 10,

$$
\begin{aligned}
& \dot{I}(t)=Q(t) \times\left[\sum_{i=1}^{K} \exp \left\{\lambda_{i} \times d_{i}(t)\right\} \times M_{i}(t)\right] \\
& \times\left[\left(\frac{T(t)-T_{\min }}{T_{\max }-T_{\min }}\right)+\left\{\sum_{j=1}^{N_{i}} f_{i, j}(t)\left(\frac{L_{e, i, j}-L_{b, i}, j}{L_{\max _{i}-L_{\min }}}\right)\right\}\right. \\
& -\left(\frac{T(t)-T_{\min }}{T_{\max }-T_{\min }}\right)\left\{\sum_{j=1}^{N_{i}} f_{i, j}(t)\left(\frac{L_{e, i, j}-L_{b, i, j}}{L_{\max _{i}}-L_{m_{i n}}}\right)\right\} \text {. }
\end{aligned}
$$


The form of Equation 12 represents the exact mathematical formulation. used in the model validation test with Zion Station data. Linear form of the density function may be chosen for cases where smaller aquatic systems are involved. 


\section{COMPUTED RESULTS AND SENSITIVITY ANALYSES}

Predicted values for the daily impingement of alewives and smelt at the Zion Station during 1974 were calculated by means of the model in the form shown by Equation 12. A sensitivity analysis was incorporated into the calculations by manipulating two factors (fish-length distribution and water temperature) in the probability function within the model. Specifically, three cases were chosen:

Case I - fish length distribution used, water temperatures omitted.

Case II - water temperature used, fish length distribution omitted.

Case III - both water temperature and fish-length distribution used.

All predicted values were compared with the results of actual observations for the same period, and the apparent variation in sensitivity was attributed to the changes in the probability-function factors.

Those input parameters that are common to the calculations for all three cases are shown in Table 1. Data on the fish density and length-frequency distribution are given in Table 2. From these data, fish-density values in terms of number of fish per thousand cubic feet per day were computed. Table 3 shows the observed and interpolated values for the volume (in cfs) of water pumped and water temperature (in ${ }^{\circ} \mathrm{C}$ ).

Figure 1 shows a plot of the daily water temperature, $T(t)$, as a function of the day of the year. Although the data shows many fluctuations in the daily temperatures, there is an underlying smooth behavior of the temperature curve, namely a warming trend through midautumn, and a cooling trend throughout the winter. The fluctuations in temperature are due to the many upwellings that are experienced in Lake Michigan during the summer and early fall months and which are an important factor in the fish behavior. Figure 2 presents a plot of the volume of water pumped per second--the $Q(t)$ factor. As expected 
Table 1. Specification of Input Parameters to Define the Model Form for Computing Daily Fish Impingements at Zion Power Station in 1974

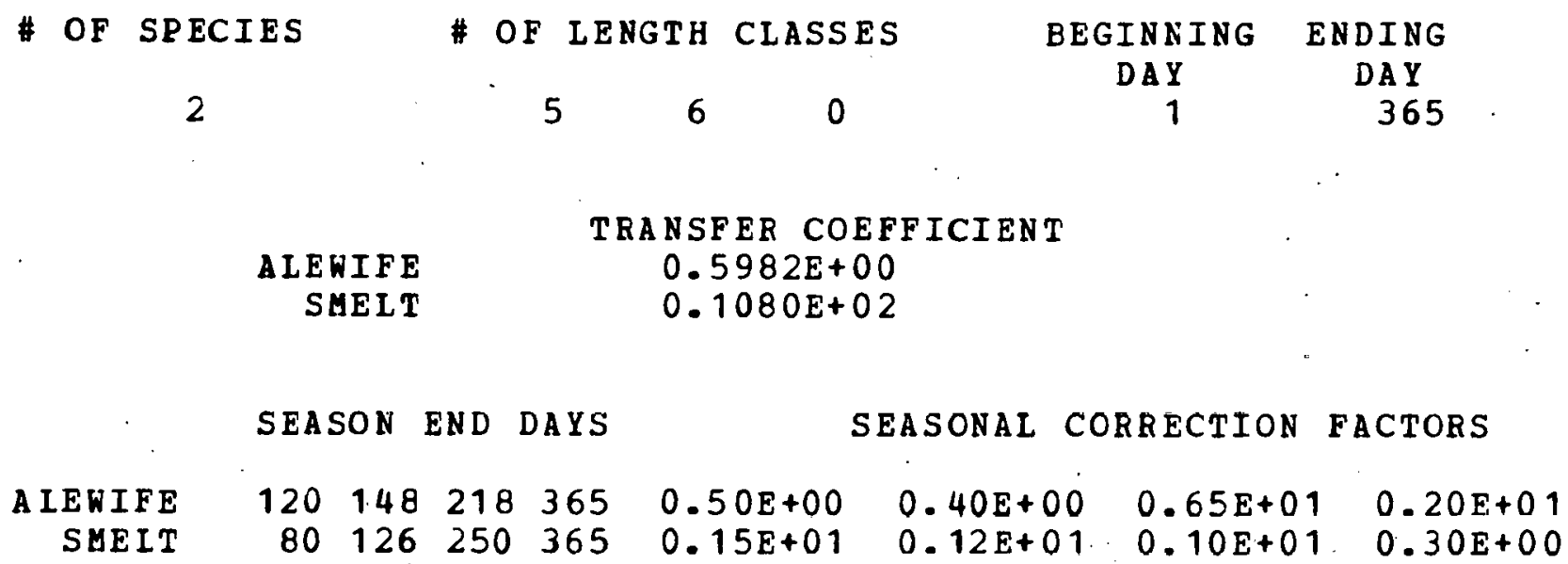

TEMPERATURE AVE. LENGTH

ALEWIFE

B EG I N NI NG ENDING

S UE IT

BEINNING

ENDING

MINIMUM
MAXIMUM

1

0.0

16.00

$$
\begin{aligned}
& 0.0 \\
& 21.00
\end{aligned}
$$$$
30.000
$$$$
275.00
$$

1

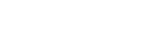

$2 \begin{array}{ccc}\text { LENGTH } & \text { CLASS } & \text { BOUNDAEIES }\end{array}$

76.00

127.00

127.00

152.00
5

178.00 260.00

\begin{tabular}{|c|c|c|c|c|c|c|}
\hline \multirow[t]{2}{*}{ SHEIT } & $\begin{array}{l}\text { MINIMUM } \\
\text { MAXIMUM }\end{array}$ & & .0 & $\begin{array}{l}30.000 \\
300.00\end{array}$ & & \\
\hline & 1 & $2^{\text {LENGTH }}$ & $\begin{array}{c}\text { CLASS } \\
3\end{array}$ & $\begin{array}{c}\text { BOUNDARIES } \\
4\end{array}$ & 5 & 6 \\
\hline $\begin{array}{l}\text { BEGINNING } \\
\text { ENDING }\end{array}$ & $\begin{array}{c}0.0 \\
102.00\end{array}$ & $\begin{array}{l}102.00 \\
127.00\end{array}$ & $\begin{array}{l}127.00 \\
152.00\end{array}$ & $\begin{array}{l}152.00 \\
178.00\end{array}$ & $\begin{array}{l}178.00 \\
230.00\end{array}$ & $\begin{array}{l}230.00 \\
300.00\end{array}$ \\
\hline
\end{tabular}

\section{TEMPERATURE AVE. LENGTH}


Table 2. Input Data on Fish Catch and Length-Relative Frequency Distribution for Traw1 Days in 1974

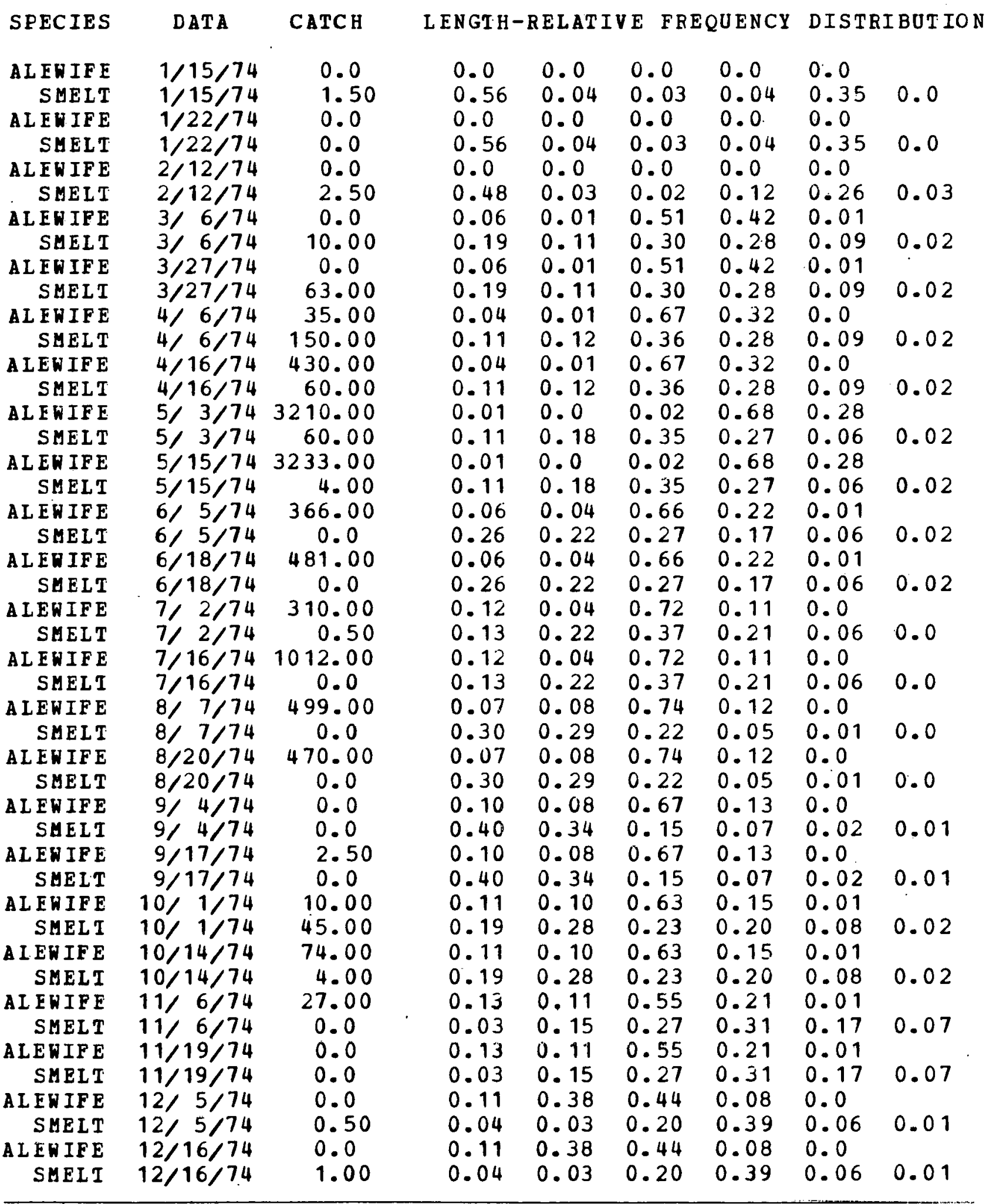


Table 3. Observed and Interpolated Values of Daily Water-Volume Pumped and Water Temperature in the Vicinity of the Zion Intakes in 1974

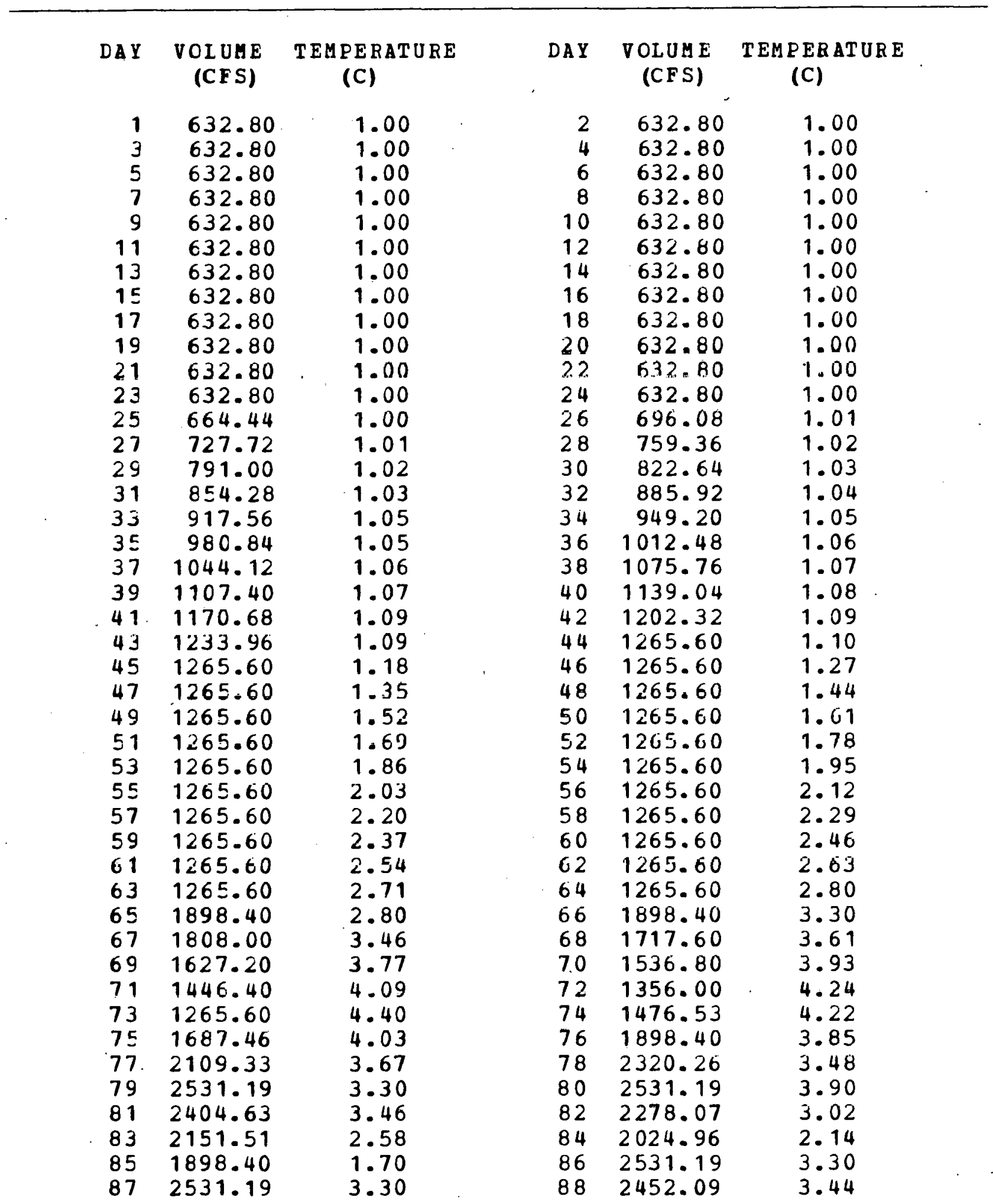


Table 3. Continued

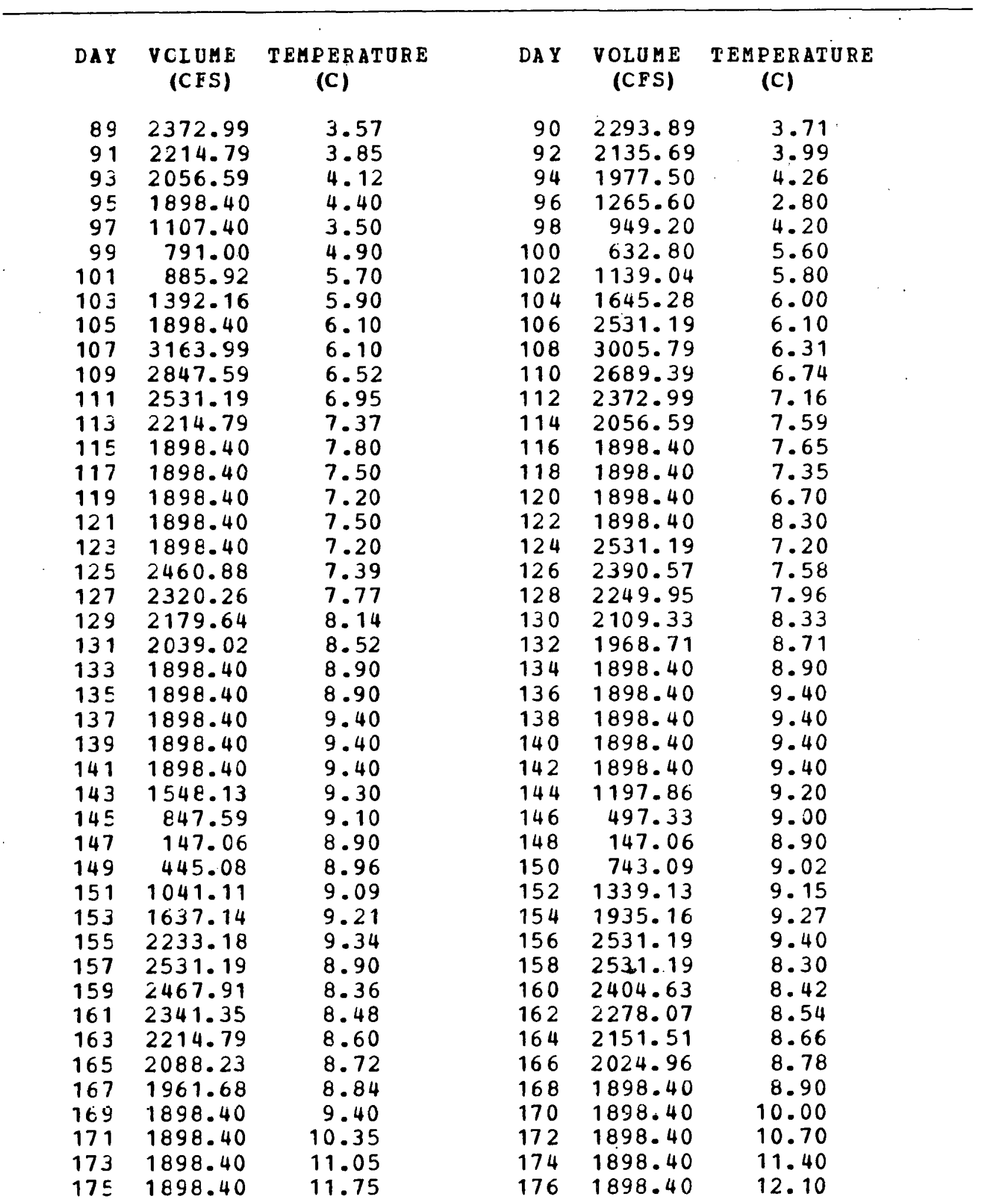


Table 3. Continued

\begin{tabular}{|c|c|c|c|c|c|}
\hline DAY & $\begin{array}{l}\text { VOLUME } \\
\text { (CFS) }\end{array}$ & $\begin{array}{l}\text { TEMPERATURE } \\
\text { (C) }\end{array}$ & DAY & $\begin{array}{l}\text { VOLUME } \\
\text { (CFS) }\end{array}$ & $\begin{array}{l}\text { TEMPERATC } \\
\text { (C) }\end{array}$ \\
\hline $\begin{array}{l}177 \\
179 \\
181 \\
183 \\
185 \\
187 \\
189 \\
191 \\
193 \\
195 \\
197 \\
199 \\
201 \\
203 \\
205 \\
207 \\
209 \\
211 \\
213 \\
215 \\
217 \\
219 \\
221 \\
223 \\
225 \\
227 \\
229 \\
231 \\
233 \\
235 \\
237 \\
239 \\
241 \\
243 \\
245 \\
247 \\
249 \\
251 \\
253 \\
255 \\
257 \\
259 \\
261 \\
263\end{array}$ & $\begin{array}{l}1898.40 \\
1898.40 \\
1898.40 \\
1898.40 \\
1898.40 \\
1898.40 \\
1898.40 \\
1898.40 \\
1898.40 \\
1898.40 \\
1898.40 \\
1898.40 \\
1898.40 \\
1898.40 \\
1898.40 \\
1898.40 \\
1898.40 \\
1898.40 \\
1898.40 \\
1898.40 \\
1898.40 \\
2531.19 \\
2531.19 \\
2784.31 \\
3037.43 \\
3290.55 \\
3543.67 \\
3796.79 \\
2531.19 \\
3163.99 \\
2531.19 \\
1898.40 \\
1265.60 \\
1687.46 \\
2109.33 \\
2531.19 \\
2531.19 \\
2742.13 \\
2953.06 \\
3163.99 \\
3480.39 \\
3796.79 \\
3796.79 \\
3796.79\end{array}$ & $\begin{array}{r}12.45 \\
12.20 \\
12.00 \\
11.80 \\
11.60 \\
11.40 \\
11.20 \\
12.03 \\
13.90 \\
15.77 \\
19.40 \\
15.35 \\
16.05 \\
16.75 \\
17.45 \\
15.60 \\
14.14 \\
12.68 \\
11.22 \\
9.76 \\
8.30 \\
8.90 \\
16.70 \\
15.92 \\
15.14 \\
14.36 \\
13.58 \\
12.80 \\
9.40 \\
15.00 \\
16.47 \\
17.93 \\
19.40 \\
18.87 \\
18.33 \\
17.80 \\
18.90 \\
15.57 \\
12.23 \\
8.90 \\
11.95 \\
15.00 \\
12.80 \\
13.70\end{array}$ & $\begin{array}{l}178 \\
180 \\
182 \\
184 \\
186 \\
188 \\
190 \\
192 \\
194 \\
196 \\
198 \\
200 \\
202 \\
204 \\
206 \\
208 \\
210 \\
212 \\
214 \\
216 \\
218 \\
220 \\
222 \\
224 \\
226 \\
228 \\
230 \\
232 \\
234 \\
236 \\
238 \\
240 \\
242 \\
244 \\
246 \\
248 \\
250 \\
252 \\
254 \\
256 \\
258 \\
260 \\
262 \\
264\end{array}$ & $\begin{array}{l}1898.40 \\
1898.40 \\
1898.40 \\
1898.40 \\
1898.40 \\
1898.40 \\
1898.40 \\
1898.40 \\
1898.40 \\
1898.40 \\
1898.40 \\
1898.40 \\
1898.40 \\
1898.40 \\
1898.40 \\
1898.40 \\
1898.40 \\
1898.40 \\
1898.40 \\
1898.40 \\
2214.79 \\
1898.40 \\
2657.75 \\
2910.87 \\
3163.99 \\
3417.11 \\
3670.23 \\
2531.19 \\
2531.19 \\
2847.59 \\
2214.79 \\
1582.00 \\
1476.53 \\
1898.40 \\
2320.26 \\
3163.99 \\
2636.66 \\
2847.59 \\
3058.53 \\
3322.19 \\
3638.59 \\
3796.79 \\
3796.79 \\
3796.79\end{array}$ & $\begin{array}{l}12.80 \\
12.10 \\
11.90 \\
11.70 \\
11.50 \\
11.30 \\
11.10 \\
12.97 \\
14.83 \\
16.70 \\
15.00 \\
15.70 \\
16.40 \\
17.10 \\
17.80 \\
14.87 \\
13.41 \\
11.95 \\
10.49 \\
9.03 \\
8.60 \\
12.80 \\
16.31 \\
15.53 \\
14.75 \\
13.97 \\
13.19 \\
11.10 \\
7.80 \\
15.73 \\
17.20 \\
18.67 \\
19.13 \\
18.60 \\
18.07 \\
17.80 \\
17.23 \\
13.90 \\
10.57 \\
10.42 \\
13.47 \\
13.90 \\
13.50\end{array}$ \\
\hline
\end{tabular}


Table 3. Continued

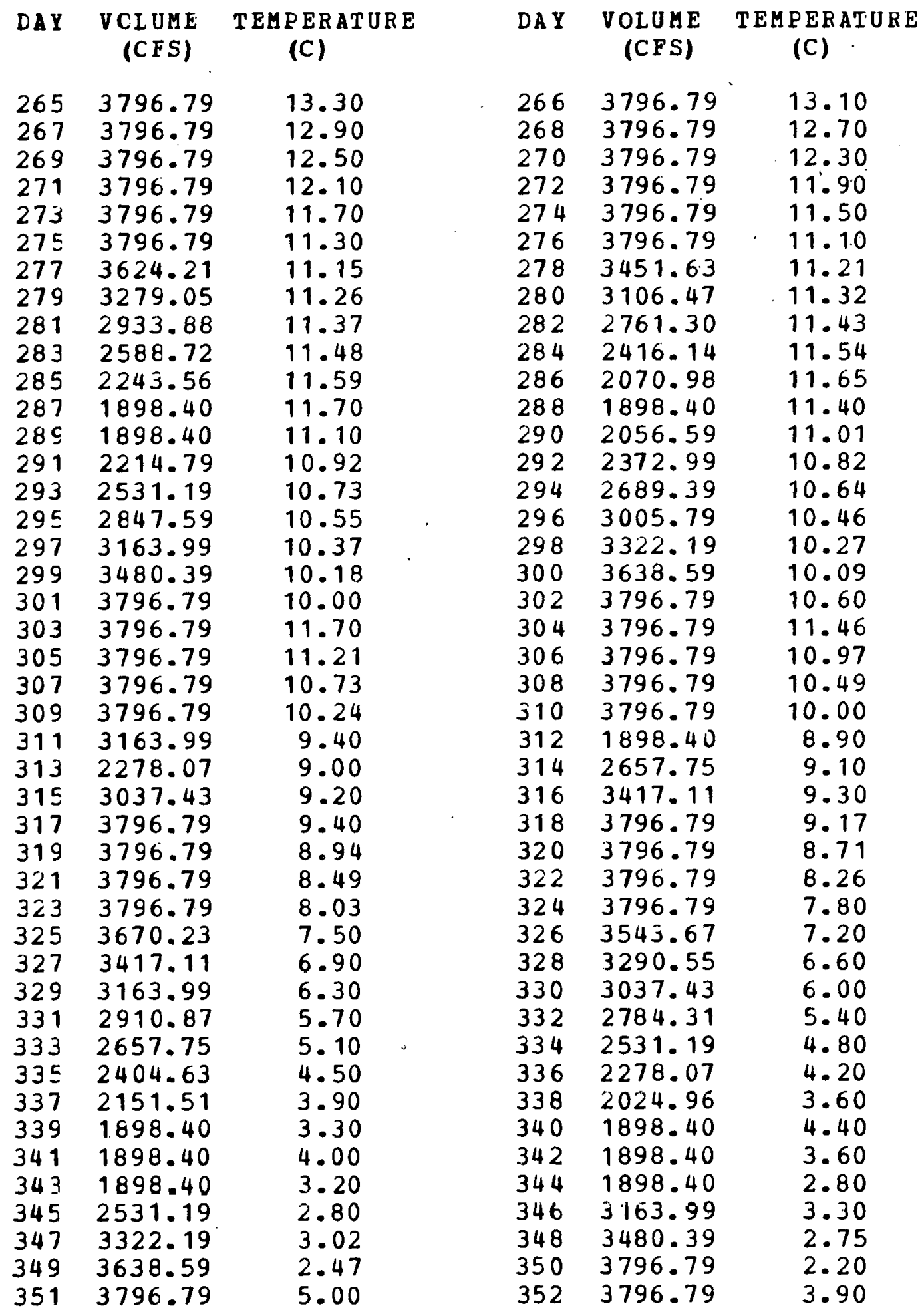


Table 3. Continued

$\begin{array}{ccc}\text { DAY } & \begin{array}{c}\text { VCIUAE } \\ \text { (CFS) }\end{array} & \begin{array}{c}\text { TEMPERATURE } \\ \text { (C) }\end{array} \\ 353 & 3796.79 & 3.94 \\ 355 & 3796.79 & 4.02 \\ 357 & 3796.79 & 4.11 \\ 359 & 3796.79 & 4.19 \\ 361 & 3796.79 & 4.27 \\ 363 & 3796.79 & 4.36 \\ 365 & 3796.79 & 4.40\end{array}$

DAY VOLUME TEMPERATURE

(CFS) (C)

$\begin{array}{llll}354 & 3796.79 & & 3.98 \\ 356 & 3796.79 & 4 & 4.07 \\ 358 & 3796.79 & & 4.15 \\ 360 & 3796.79 & & 4.23 \\ 362 & 3796.79 & & 4.32 \\ 364 & 3796.79 & 4.40\end{array}$




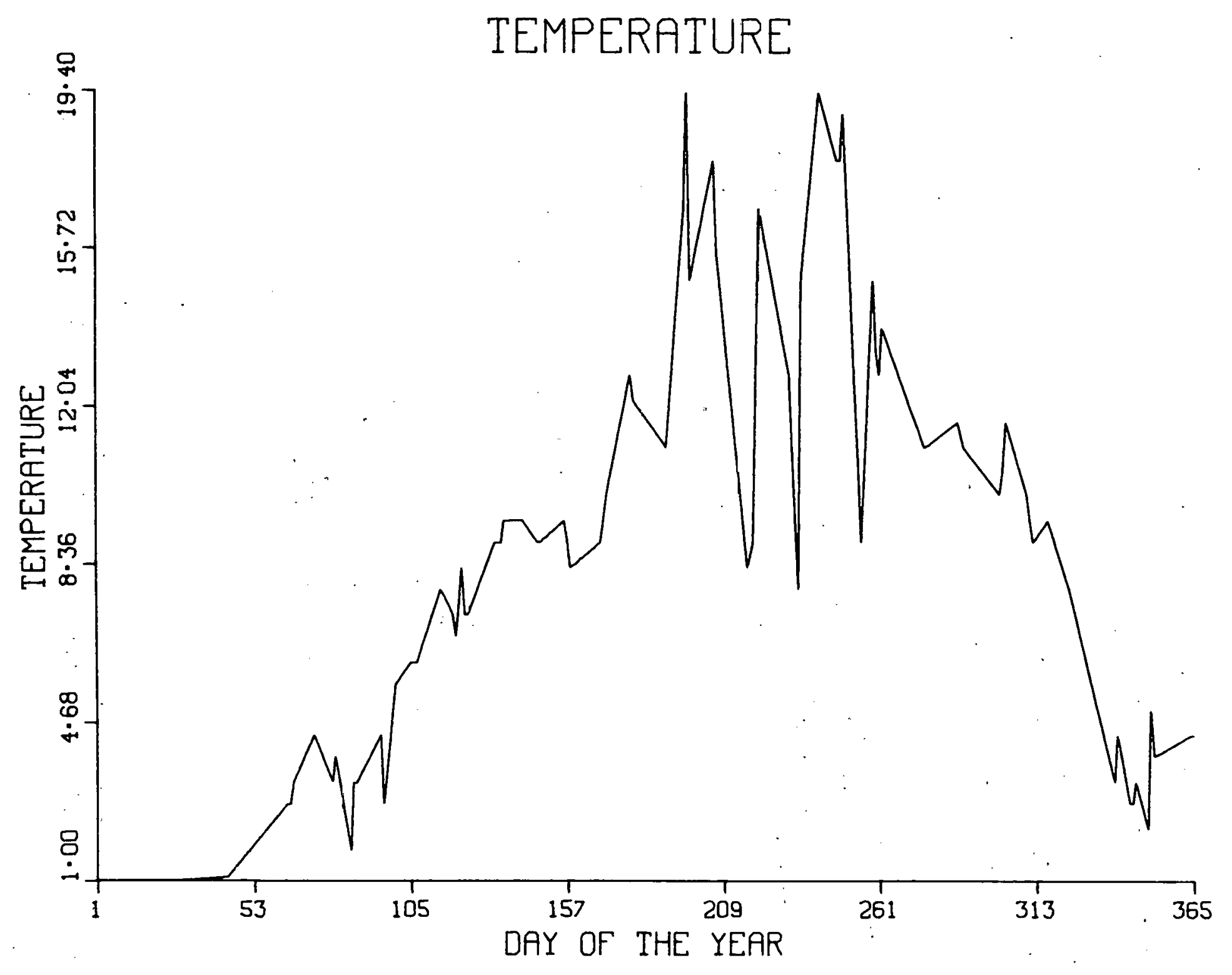

Fig. 1. Water Temperature $\left({ }^{\circ} \mathrm{C}\right)$ at the Intakes of the Zion Station during 1974. 


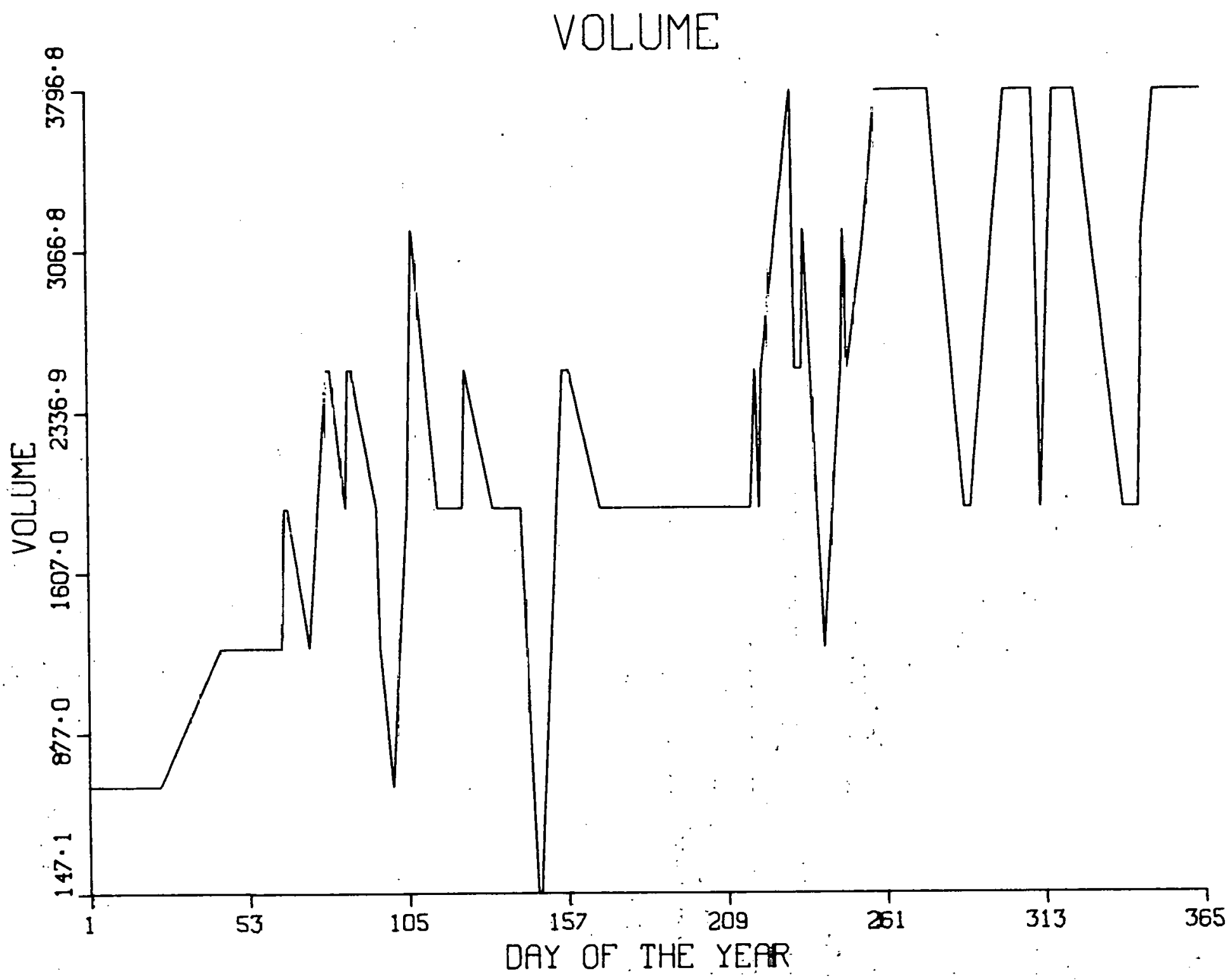

Fig. 2. Volume of Water (cfs) Pumped through the Intakes of the Zion Station during 1974. 
there are a number of discrete changes in the volume of water being pumped. These sudden changes may be producing drastic changes in the fish-impingement process.

The daily fish-density values for alewives and rainbow smelt, $d_{i}(t)$, used in computing the impingement predictions, are plotted in Figures 3 and 4 as functions of the day of the year. These figures show periods with a fishabundance value of zero for both species; however, impingement observations during these periods indicate that fish are present (particularly alewives) in the intake area and subject to high impingement probabilities. These zero values indicate that the determination of $\mathrm{fish}$ abundance in the vicinity of the cooling-water intake is inadequate. Thus we find that the data on fish density--the most important factor affecting fish impingement--are unreliable for predicting impingement rates during such periods.

By use of the model with the exponential form of the density function, $d_{i}(t)$, and by experimenting with the two factors--temperature and length class--in the probability function, the results for the three cases were obtained. In the following sections we present the results and discuss the effects of the water-temperature and fish-length distribution factors on the predictability of daily fish impingement at the Zion Station for the year 1974. Where appropriate, the inadequacy of the fish-density measurements is emphasized in discussions of the model's performance in predicting daily fish impingement.

\subsection{CASE I FOR THE EXPONENTIAL MODEL}

The predicted values for Case I (in which only the length-frequency factor is included) are given in Table 4. In Figures 5 through 7, the predicted values are shown as a solid line against the scatter of observed data. It is apparent that the behavior of predicted values resembles that of the observed data, but the numerical values of the predictions are much smaller.

The fish-impingement probability function for alewives is shown in Figure 8, and for rainbow smelt in Figure 9; the numerical results are given in Table 5. It should be noted that due to gross resolution of the length- 
FISH DENSITY

ALEWIFE

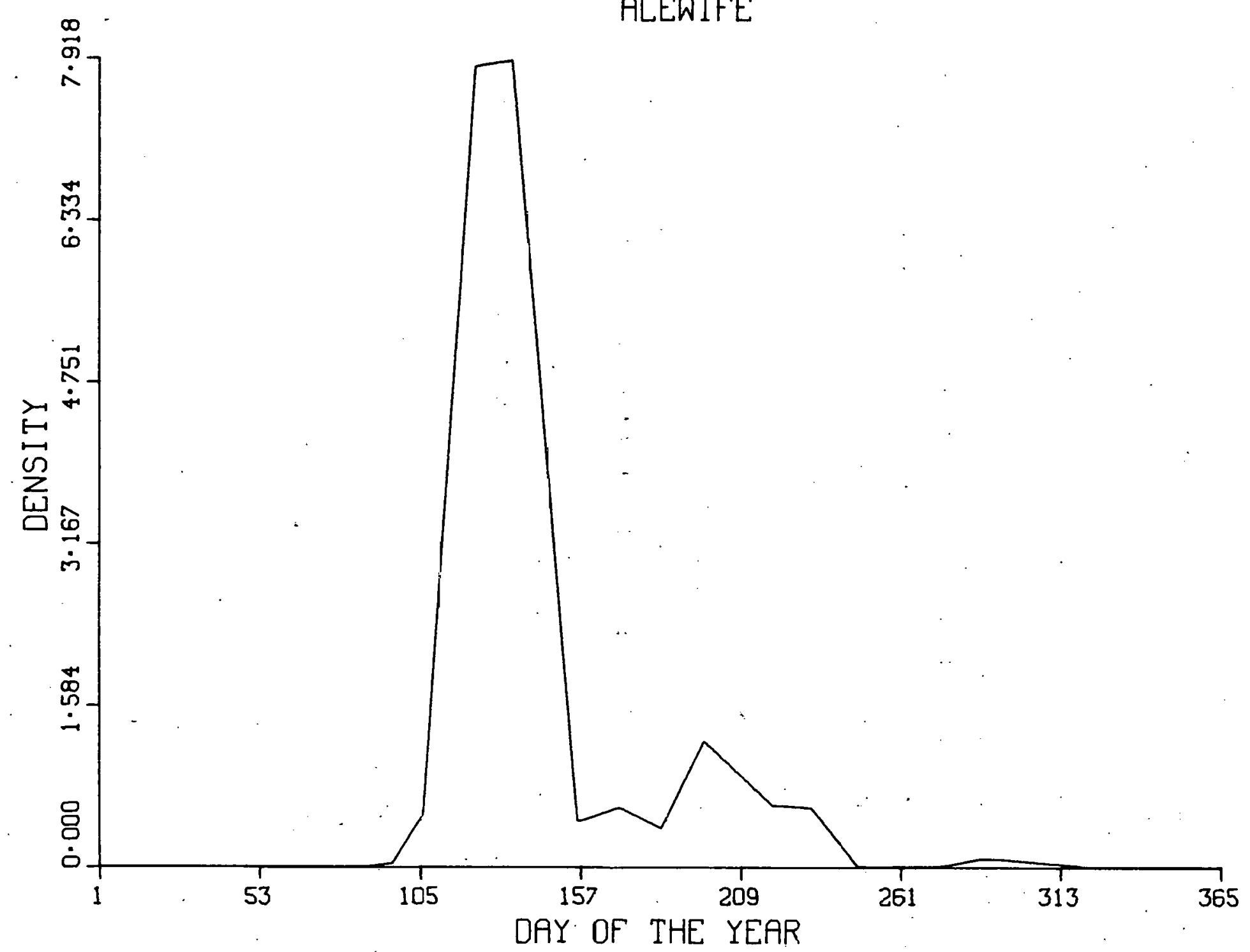

Fig. 3. Alewife Fish Density (number/1000 $\mathrm{ft}^{3} /$ day) in the Vicinity of the Intakes of the Zion Station during 1974. 


\section{FISH DENSITY}

SMELT

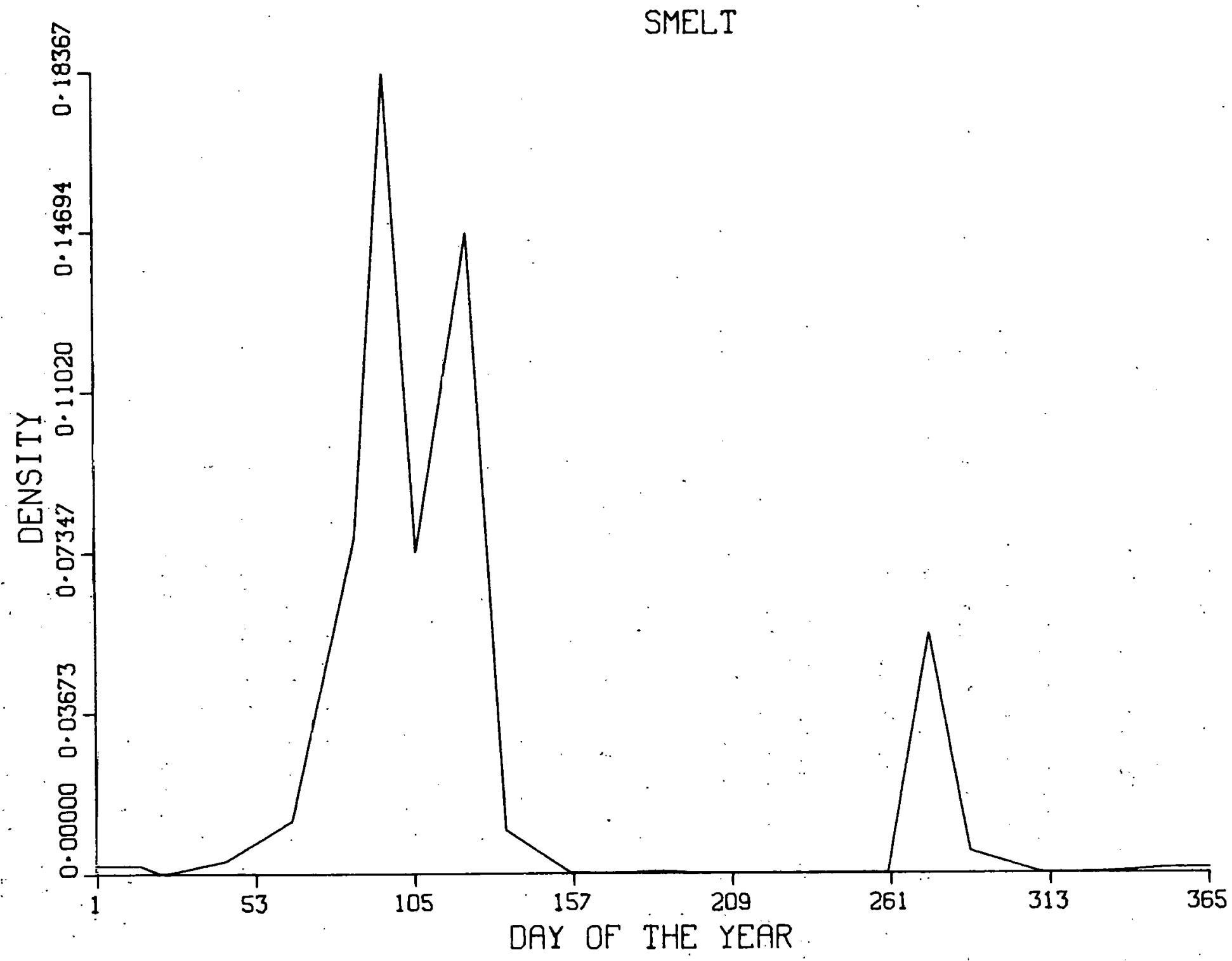

Fig. 4. Smelt Fish Density (number/1000 $\mathrm{ft}^{3} /$ day) in the Vicinity of the Intakes of the Zion Station during 1974. 
frequency classes, the probability function behavior is relatively smooth and varies only slightly between successive days. The numerical values of the impingement probabilities (Table 5) are fairly small, giving rise to predicted fish impingement values that are smaller than the observed values (Figs. 5-7).

\subsection{CASE II FOR THE EXPONENTIAL MODEL}

Table 6 shows the computed fish impingements for Case II (in which only the water-temperature distribution factor is included). Figures 10 through 12 show that the predicted values (solid line) mimic the observed fish impingements for both the species. However, again the numerical. values are noticeably small compared to the observed values.

The fish-impingement probability function is shown in Figures 13 and 14 and the numerical results in Table 7 . The probability function shows a higher degree of variation because of the much more rapid changes in the temperature as a function of day of the year. Therefore, the numerical values of the probabilities produce predicted values that are higher than those given in Case I. These results show that perhaps the calculation of fish-impingement probabilities and daily fish-impingement values is more sensitive to the temperature behavior in time (and hence to upwelling and lack of upwelling) than to the length-frequency classes, which have very small resolution.

\subsection{CASE III FOR THE EXPONENTIAL MODEL}

Table 8 shows the computed fish-impingement predictions for Case III (both factors included). Figures 15 through 17 show the predicted values with the scatter of observed fish impingement for both of the species and the total impingement. In this case it is noted that the numerical values of the predictions are much closer to the observed fish-impingement values. The probability function and the fish-impingement prediction values show that the combination of length class and temperature provides a fish-impingement probability function that is perhaps much closer to that determining behavior of the process and therefore yields a better prediction. The fish-impingement probability function is shown in Figures 18 and 19, and the numeric results in Table 9 . 
Table 4. Daily Fish-Impingement Predictions Calculated According to Case-I Specifications

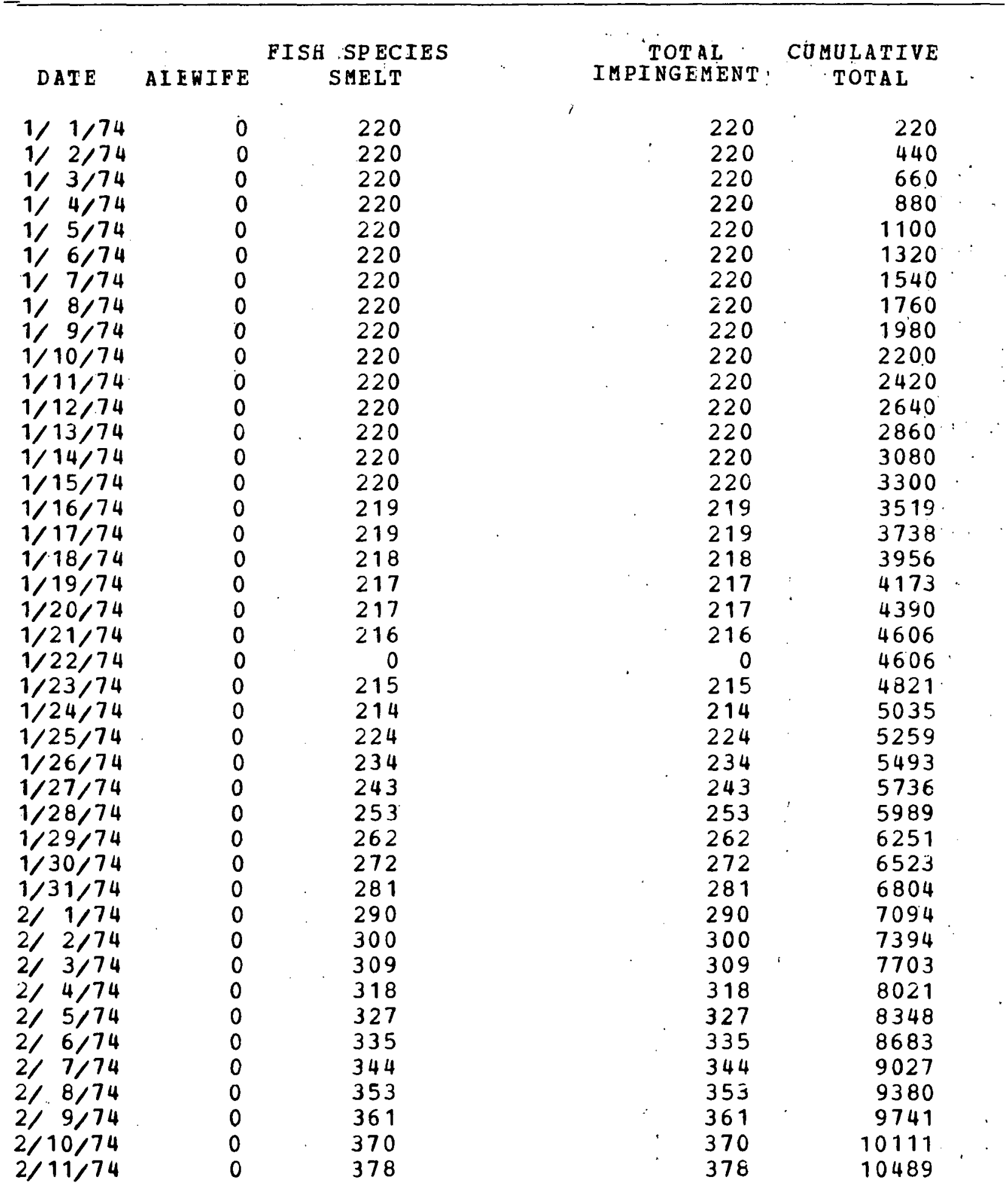


Table 4: Continued

\begin{tabular}{|c|c|c|c|c|}
\hline DATE & AIE IIFE & $\begin{array}{c}\text { FISH SPECIES } \\
\text { SMELT }\end{array}$ & $\begin{array}{c}\text { TOTAL } \\
\text { I MPI NGEMENT }\end{array}$ & $\begin{array}{c}\text { CUMULATIVE } \\
\text { TOTAL }\end{array}$ \\
\hline $\begin{array}{l}2 / 12 / 74 \\
2 / 13 / 74 \\
2 / 14 / 74 \\
2 / 15 / 74 \\
2 / 16 / 74 \\
2 / 17 / 74 \\
2 / 18 / 74 \\
2 / 19 / 74 \\
2 / 20 / 74 \\
2 / 21 / 74 \\
2 / 22 / 74 \\
2 / 23 / 74 \\
2 / 24 / 74 \\
2 / 25 / 74 \\
2 / 26 / 74 \\
2 / 27 / 74 \\
2 / 28 / 74 \\
3 / 1 / 74 \\
3 / 2 / 74 \\
3 / 3 / 74 \\
3 / 4 / 74 \\
3 / 5 / 74 \\
3 / 6 / 74 \\
3 / 7 / 74 \\
3 / 8 / 74 \\
3 / 9 / 74 \\
3 / 10 / 74 \\
3 / 11 / 74 \\
3 / 12 / 74 \\
3 / 13 / 74 \\
3 / 14 / 74 \\
3 / 15 / 74 \\
3 / 16 / 74 \\
3 / 17 / 74 \\
3 / 18 / 74 \\
3 / 19 / 74 \\
3 / 20 / 74 \\
3 / 21 / 74 \\
3 / 22 / 74 \\
3 / 23 / 74 \\
3 / 24 / 74 \\
3 / 25 / 74\end{array}$ & $\begin{array}{l}0 \\
0 \\
0 \\
0 \\
0 \\
0 \\
0 \\
0 \\
0 \\
0 \\
0 \\
0 \\
0 \\
0 \\
0 \\
0 \\
0 \\
0 \\
0 \\
0 \\
0 \\
0 \\
0 \\
0 \\
0 \\
0 \\
0 \\
0 \\
0 \\
0 \\
0 \\
0 \\
0 \\
0 \\
0 \\
0 \\
0 \\
0 \\
0 \\
0 \\
0 \\
0\end{array}$ & $\begin{array}{l}387 \\
392 \\
389 \\
384 \\
380 \\
376 \\
372 \\
368 \\
364 \\
359 \\
355 \\
351 \\
346 \\
342 \\
337 \\
333 \\
328 \\
323 \\
319 \\
314 \\
309 \\
304 \\
449 \\
464 \\
457 \\
449 \\
440 \\
429 \\
418 \\
405 \\
391 \\
471 \\
557 \\
648 \\
744 \\
847 \\
955 \\
987 \\
776 \\
760 \\
742 \\
722\end{array}$ & $\begin{array}{l}387 \\
392 \\
389 \\
384 \\
380 \\
376 \\
372 \\
368 \\
364 \\
359 \\
355 \\
351 \\
346 \\
342 \\
337 \\
333 \\
328 \\
323 \\
319 \\
314 \\
309 \\
304 \\
449 \\
464 \\
457 \\
449 \\
440 \\
429 \\
418 \\
405 \\
391 \\
471 \\
557 \\
648 \\
744 \\
847 \\
955 \\
987 \\
776 \\
760 \\
742 \\
722\end{array}$ & $\begin{array}{l}10876 \\
11268 \\
11657 \\
12041 \\
12421 \\
12797 \\
13169 \\
13537 \\
13901 \\
14260 \\
14615 \\
14966 \\
15312 \\
15654 \\
15991 \\
16324 \\
16652 \\
16975 \\
17294 \\
17608 \\
17917 \\
18221 \\
18670 \\
19134 \\
1\end{array}$ \\
\hline
\end{tabular}


Table 4. Continued

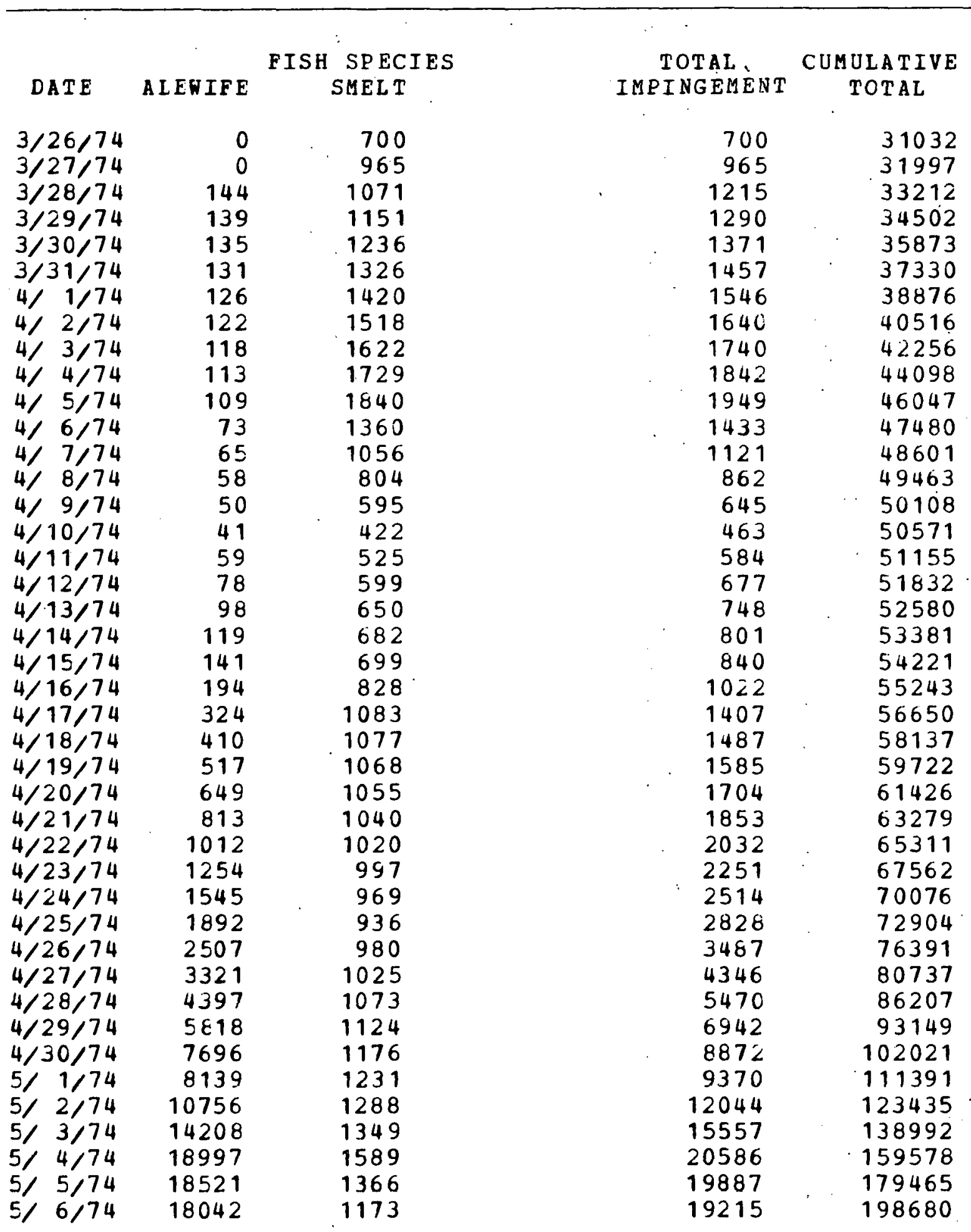


Table 4. Continued

\begin{tabular}{|c|c|c|c|c|}
\hline DATE & ALEWIFE & $\begin{array}{c}\text { EISH SPECIES } \\
\text { SMELT }\end{array}$ & $\begin{array}{c}\text { TOTAL } \\
\text { IMPINGEMENT }\end{array}$ & $\begin{array}{c}\text { CUMULATIVE } \\
\text { TOTAL }\end{array}$ \\
\hline $\begin{array}{l}5 / 7 / 74 \\
5 / 8 / 74 \\
5 / 9 / 74 \\
5 / 10 / 74 \\
5 / 11 / 74 \\
5 / 12 / 74 \\
5 / 13 / 74 \\
5 / 14 / 74 \\
5 / 15 / 74 \\
5 / 16 / 74 \\
5 / 17 / 74 \\
5 / 18 / 74 \\
5 / 19 / 74 \\
5 / 20 / 74 \\
5 / 21 / 74 \\
5 / 22 / 74 \\
5 / 23 / 74 \\
5 / 24 / 74 \\
5 / 25 / 74 \\
5 / 26 / 74 \\
5 / 27 / 74 \\
5 / 28 / 74 \\
5 / 29 / 74 \\
5 / 30 / 74 \\
5 / 31 / 74 \\
6 / 1 / 74 \\
6 / 2 / 74 \\
6 / 3 / 74 \\
6 / 4 / 74 \\
6 / 5 / 74 \\
6 / 6 / 74 \\
6 / 7 / 74 \\
6 / 8 / 74 \\
6 / 9 / 74 \\
6 / 10 / 74 \\
6 / 11 / 74 \\
6 / 12 / 74 \\
6 / 73 / 74 \\
6 / 14 / 74 \\
6 / 15 / 74 \\
6 / 16 / 74 \\
6 / 17 / 74\end{array}$ & $\begin{array}{r}17561 \\
17 C 77 \\
16589 \\
16099 \\
15607 \\
15111 \\
14612 \\
14653 \\
14694 \\
11691 \\
9299 \\
7395 \\
5879 \\
4672 \\
3712 \\
2949 \\
1909 \\
1173 \\
658 \\
306 \\
72 \\
57 \\
2220 \\
2935 \\
3256 \\
3314 \\
3204 \\
2995 \\
2731 \\
2444 \\
2460 \\
2476 \\
2430 \\
2383 \\
2335 \\
2287 \\
2238 \\
2188 \\
2138 \\
2086 \\
2034 \\
1981\end{array}$ & $\begin{array}{r}838 \\
719 \\
615 \\
526 \\
450 \\
384 \\
327 \\
289 \\
256 \\
257 \\
258 \\
260 \\
261 \\
262 \\
264 \\
265 \\
217 \\
169 \\
120 \\
71 \\
21 \\
21 \\
64 \\
107 \\
151 \\
195 \\
239 \\
284 \\
329 \\
0 \\
0 \\
0 \\
0 \\
0 \\
0 \\
0 \\
0 \\
0 \\
0 \\
0 \\
0 \\
0\end{array}$ & $\begin{array}{r}18399 \\
17796 \\
17204 \\
16625 \\
16057 \\
15495 \\
14939 \\
14942 \\
14950 \\
11948 \\
9557 \\
7655 \\
6140 \\
4934 \\
3976 \\
3214 \\
2126 \\
1342 \\
778 \\
377 \\
99 \\
78 \\
2284 \\
3042 \\
3407 \\
3509 \\
3443 \\
3279 \\
3060 \\
2444 \\
2460 \\
2476 \\
2430 \\
2383 \\
2335 \\
2287 \\
2238 \\
2188 \\
2138 \\
2086 \\
2034 \\
1981\end{array}$ & $\begin{array}{l}217079 \\
234875 \\
252079 \\
268704 \\
284761 \\
300256 \\
315195 \\
330137 \\
345087 \\
357035 \\
366592 \\
374247 \\
380387 \\
385321 \\
389297 \\
392511 \\
394637 \\
395979 \\
396757 \\
397134 \\
397227 \\
397305 \\
399589 \\
402631 \\
406038 \\
11095117 \\
412990 \\
416269 \\
419329 \\
421773 \\
424233 \\
426709 \\
429139 \\
431522 \\
433857 \\
436144 \\
438382 \\
440570 \\
442708 \\
444794 \\
446828 \\
448809\end{array}$ \\
\hline
\end{tabular}


Table 4. Continued

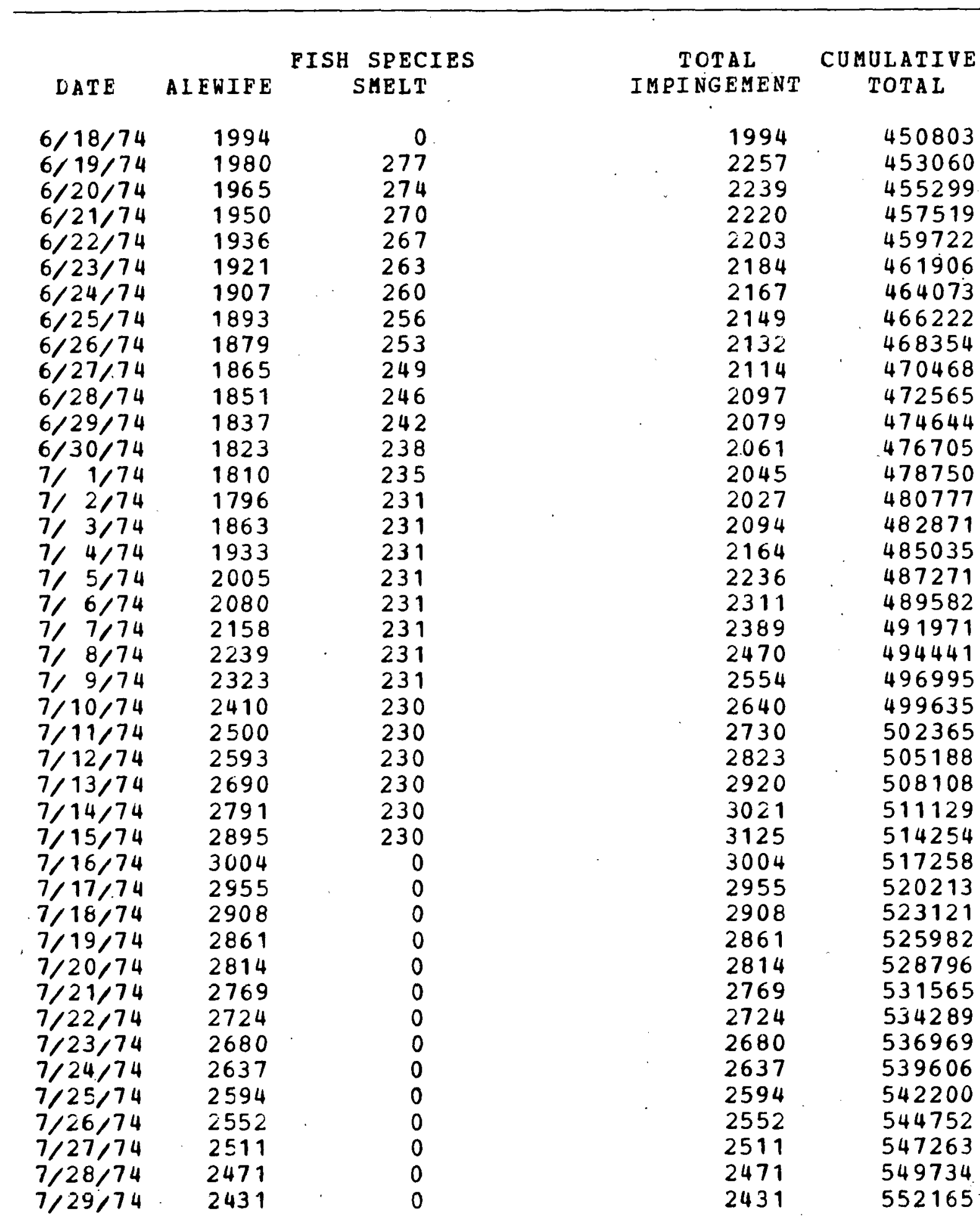


Table 4. Continued

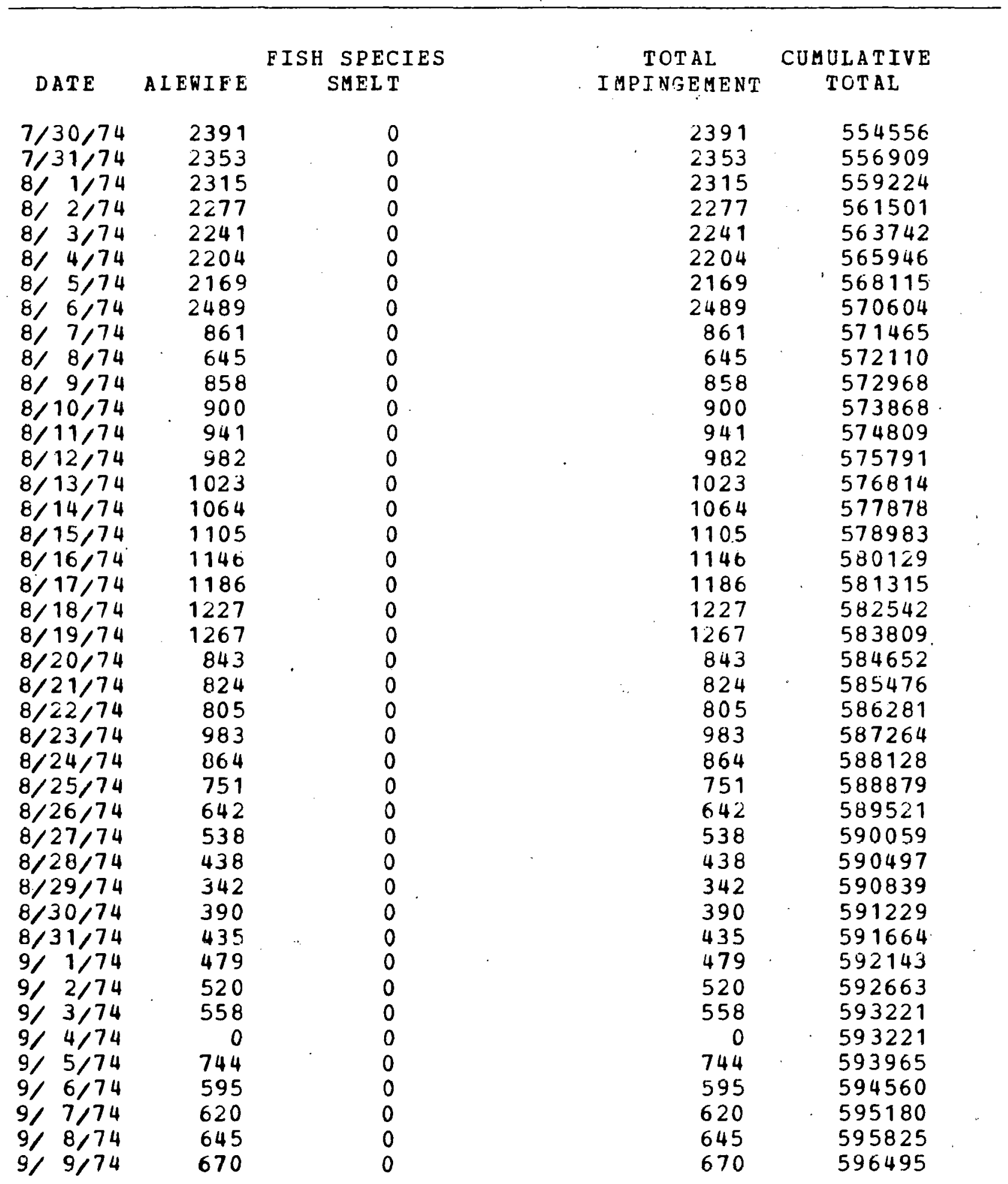


Table 4. Continued

\begin{tabular}{|c|c|c|c|c|}
\hline DATE & ALEWIFE & $\begin{array}{c}\text { FISH } \\
\text { SMELT }\end{array}$ & $\begin{array}{c}\text { TOTAL } \\
\text { IMPINGEMEN'I' }\end{array}$ & $\begin{array}{c}\text { CUMULATIVE } \\
\text { TOTAL }\end{array}$ \\
\hline $\begin{array}{l}9 / 10 / 74 \\
9 / 11 / 74 \\
9 / 12 / 74 \\
9 / 13 / 74 \\
9 / 14 / 74 \\
9 / 15 / 74 \\
9 / 16 / 74 \\
9 / 17 / 74 \\
9 / 18 / 74 \\
9 / 19 / 74 \\
9 / 20 / 74 \\
9 / 21 / 74 \\
9 / 22 / 74 \\
9 / 23 / 74 \\
9 / 24 / 74 \\
9 / 25 / 74 \\
9 / 26 / 74 \\
9 / 27 / 74 \\
9 / 28 / 74 \\
9 / 29 / 74 \\
9 / 30 / 74 \\
10 / 1 / 74 \\
10 / 2 / 74 \\
10 / 3 / 74 \\
10 / 4 / 74 \\
10 / 5 / 74 \\
10 / 6 / 74 \\
10 / 7 / 74 \\
10 / 8 / 74 \\
10 / 9 / 74 \\
10 / 10 / 74 \\
10 / 11 / 74 \\
10 / 12 / 74 \\
10 / 13 / 74 \\
10 / 14 / 74 \\
10 / 15 / 74 \\
10 / 16 / 74 \\
10 / 17 / 74 \\
10 / 18 / 74 \\
10 / 19 / 74 \\
10 / 20 / 74 \\
10 / 21 / 74\end{array}$ & $\begin{array}{l}695 \\
720 \\
745 \\
782 \\
820 \\
857 \\
894 \\
895 \\
899 \\
903 \\
908 \\
912 \\
917 \\
921 \\
925 \\
930 \\
934 \\
939 \\
943 \\
947 \\
952 \\
956 \\
960 \\
963 \\
923 \\
882 \\
841 \\
800 \\
758 \\
716 \\
674 \\
631 \\
588 \\
545 \\
501 \\
501 \\
501 \\
543 \\
584 \\
626 \\
668 \\
709\end{array}$ & $\begin{array}{r}0 \\
0 \\
0 \\
0 \\
0 \\
0 \\
0 \\
0 \\
194 \\
200 \\
206 \\
212 \\
219 \\
226 \\
232 \\
239 \\
246 \\
254 \\
261 \\
269 \\
276 \\
284 \\
273 \\
262 \\
240 \\
219 \\
199 \\
181 \\
164 \\
148 \\
133 \\
119 \\
106 \\
94 \\
83 \\
82 \\
82 \\
88 \\
94 \\
101 \\
107 \\
113\end{array}$ & $\begin{array}{l}695 \\
720 \\
745 \\
782 \\
820 \\
857 \\
894 \\
895 \\
1093 \\
1103 \\
1114 \\
1124 \\
1136 \\
1147 \\
1157 \\
1169 \\
1180 \\
1193 \\
1204 \\
1216 \\
1228 \\
1240 \\
1233 \\
1225 \\
1163 \\
1101 \\
1040 \\
981 \\
922 \\
864 \\
807 \\
750 \\
694 \\
639 \\
584 \\
583 \\
583 \\
631 \\
678 \\
727 \\
775 \\
822\end{array}$ & $\begin{array}{l}597190 \\
597910 \\
598655 \\
599437 \\
600257 \\
601114 \\
602008 \\
602903 \\
603996 \\
605099 \\
606213 \\
607337 \\
608473 \\
609620 \\
610777 \\
611946 \\
613126 \\
614319 \\
615523 \\
616739 \\
617967 \\
619207 \\
620440 \\
621665 \\
622828 \\
623929 \\
624969 \\
625950 \\
626872 \\
627736 \\
628543 \\
629293 \\
629987 \\
630626 \\
631210 \\
631793 \\
632376 \\
633007 \\
633685 \\
634412 \\
635187 \\
636009\end{array}$ \\
\hline
\end{tabular}


Table 4. Continued

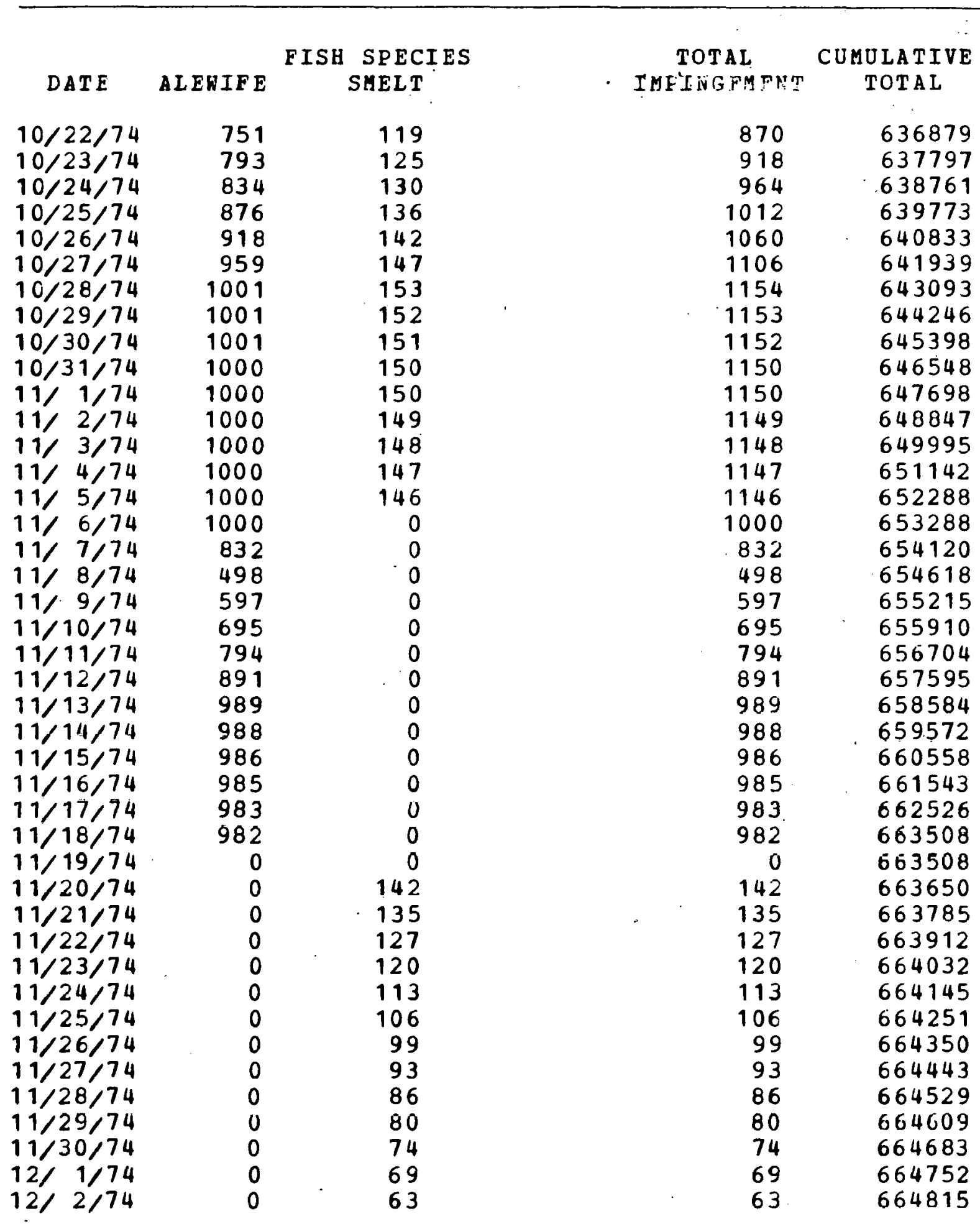


Table 4. Continued

\begin{tabular}{|c|c|c|c|c|}
\hline D ATE & ALEWIFE & $\begin{array}{c}\text { FISH } \text { SPECIES } \\
\text { SHELT }\end{array}$ & $\begin{array}{c}\text { TOTAL } \\
\text { IMPINGEMENT }\end{array}$ & $\begin{array}{c}\text { CUMULATIVE } \\
\text { TOTAL }\end{array}$ \\
\hline $\begin{array}{l}12 / 3 / 74 \\
12 / 4 / 74 \\
12 / 5 / 74 \\
12 / 6 / 74 \\
12 / 7 / 74 \\
12 / 8 / 74 \\
12 / 9 / 74 \\
12 / 10 / 74 \\
12 / 11 / 74 \\
12 / 12 / 74 \\
12 / 13 / 74 \\
12 / 14 / 74 \\
12 / 15 / 74 \\
12 / 16 / 74 \\
12 / 17 / 74 \\
12 / 18 / 74 \\
12 / 19 / 74 \\
12 / 20 / 74 \\
12 / 21 / 74 \\
12 / 22 / 74 \\
12 / 23 / 74 \\
12 / 24 / 74 \\
12 / 25 / 74 \\
12 / 26 / 74 \\
12 / 27 / 74 \\
12 / 28 / 74 \\
12 / 29 / 74 \\
12 / 30 / 74 \\
12 / 31 / 74\end{array}$ & $\begin{array}{l}0 \\
0 \\
0 \\
0 \\
0 \\
0 \\
0 \\
0 \\
0 \\
0 \\
0 \\
0 \\
0 \\
0 \\
0 \\
0 \\
0 \\
0 \\
0 \\
0 \\
0 \\
0 \\
0 \\
0 \\
0 \\
0 \\
0 \\
0 \\
0\end{array}$ & $\begin{array}{l}58 \\
53 \\
48 \\
48 \\
48 \\
48 \\
48 \\
48 \\
64 \\
80 \\
84 \\
88 \\
92 \\
97 \\
97 \\
97 \\
97 \\
97 \\
97 \\
97 \\
97 \\
97 \\
97 \\
97 \\
97 \\
97 \\
97 \\
97 \\
97\end{array}$ & $\begin{array}{l}58 \\
53 \\
48 \\
48 \\
48 \\
48 \\
48 \\
48 \\
64 \\
80 \\
84 \\
88 \\
92 \\
97 \\
97 \\
97 \\
97 \\
97 \\
97 \\
97 \\
97 \\
97 \\
97 \\
97 \\
97 \\
97 \\
97 \\
97 \\
97\end{array}$ & $\begin{array}{l}664873 \\
664926 \\
664974 \\
665022 \\
665070 \\
665118 \\
665166 \\
665214 \\
665278 \\
665358 \\
665442 \\
665530 \\
665622 \\
665719 \\
665816 \\
665913 \\
666010 \\
666107 \\
666204 \\
666301 \\
666398 \\
666495 \\
666592 \\
666689 \\
666786 \\
666883 \\
666980 \\
667077 \\
667174\end{array}$ \\
\hline
\end{tabular}




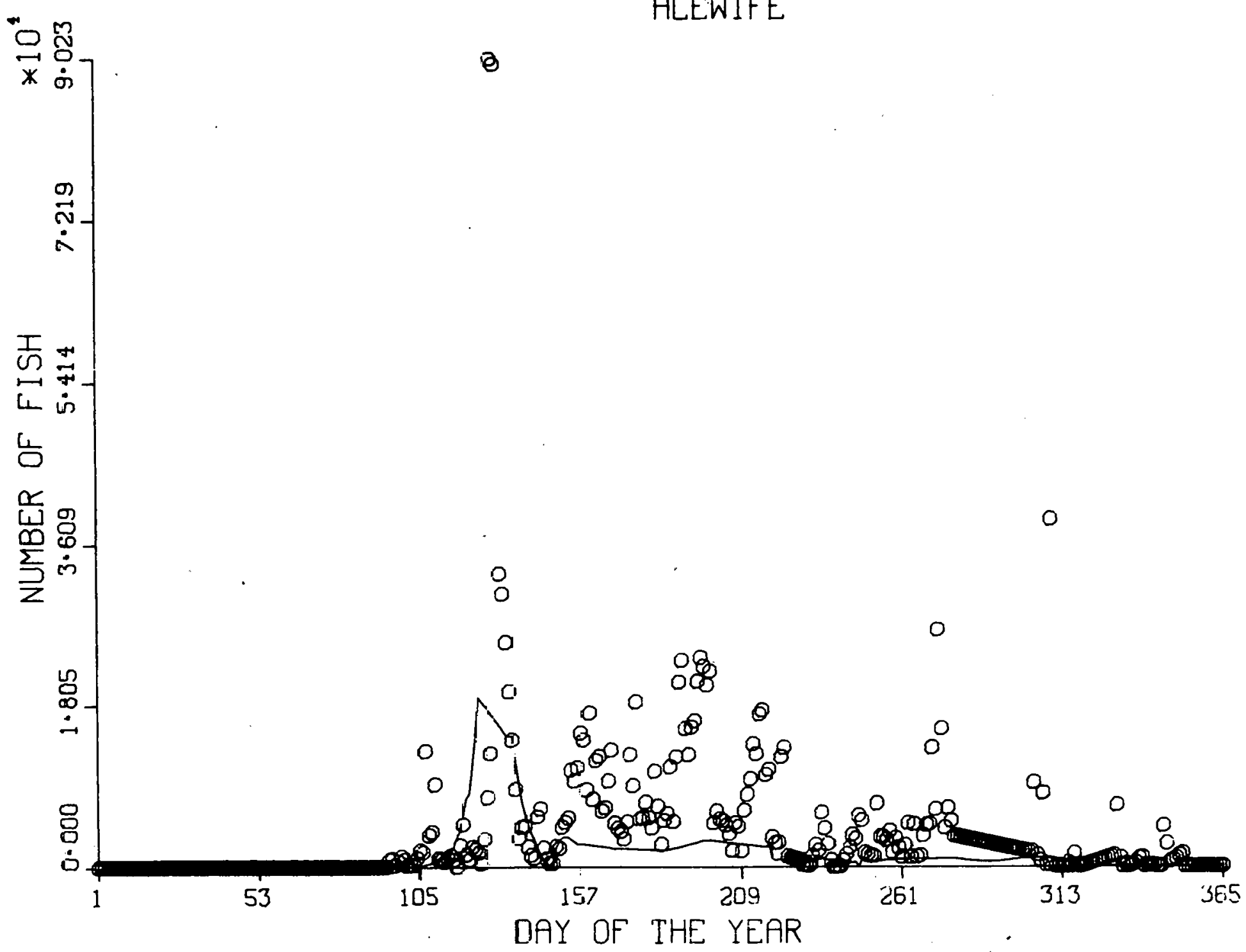

Fig. 5. Predicted Impingement (solid line) for Case I and Observed Impingement (circles) of Alewives of the Zicn Station during 1974 (No. of fish/day). 


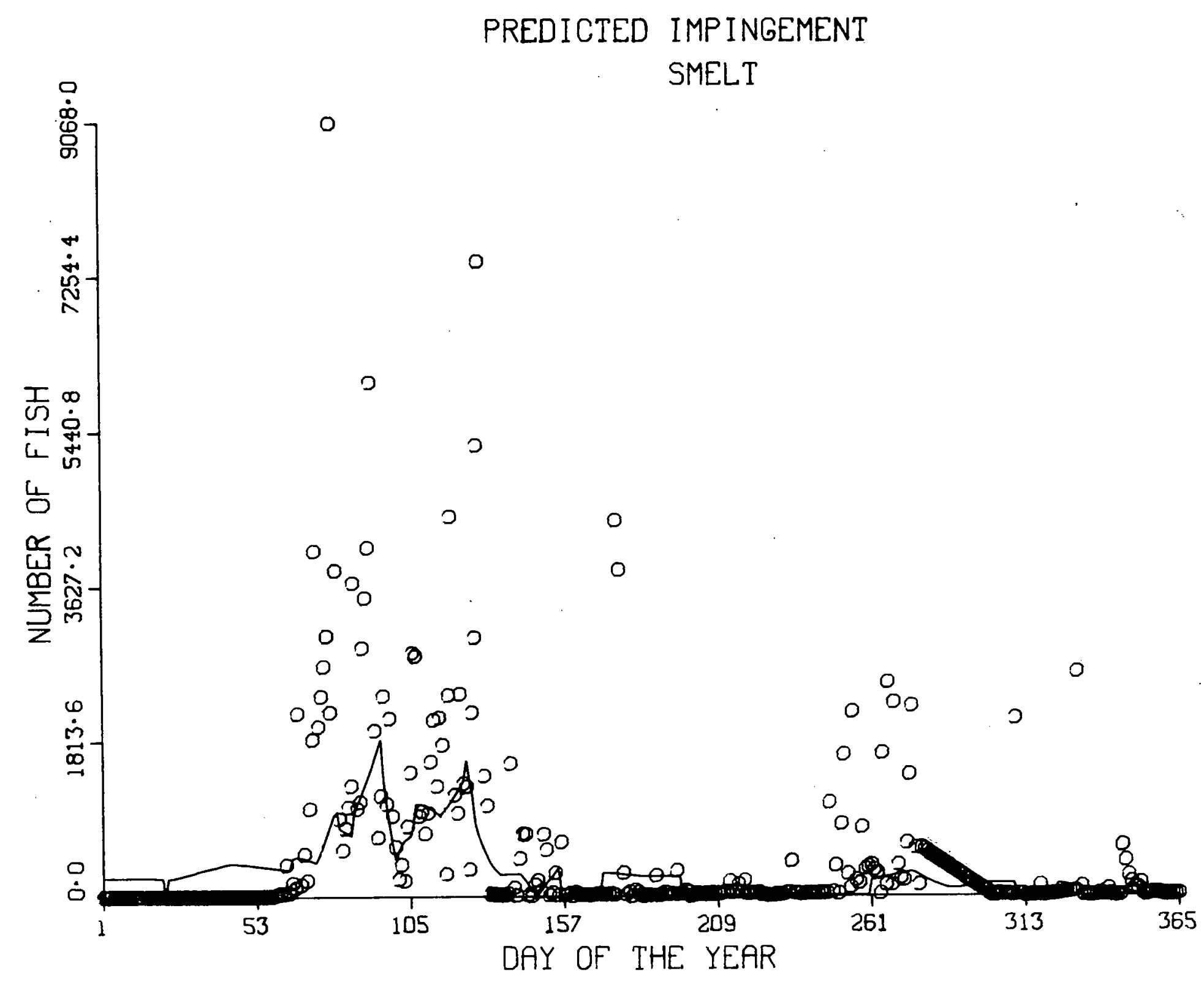

Fig. 6. Predicted Impingement (solid line) for Case I and Observed Impingement (circles) of Smelt at the Zion Station during 1974 (No. of fish/day). 


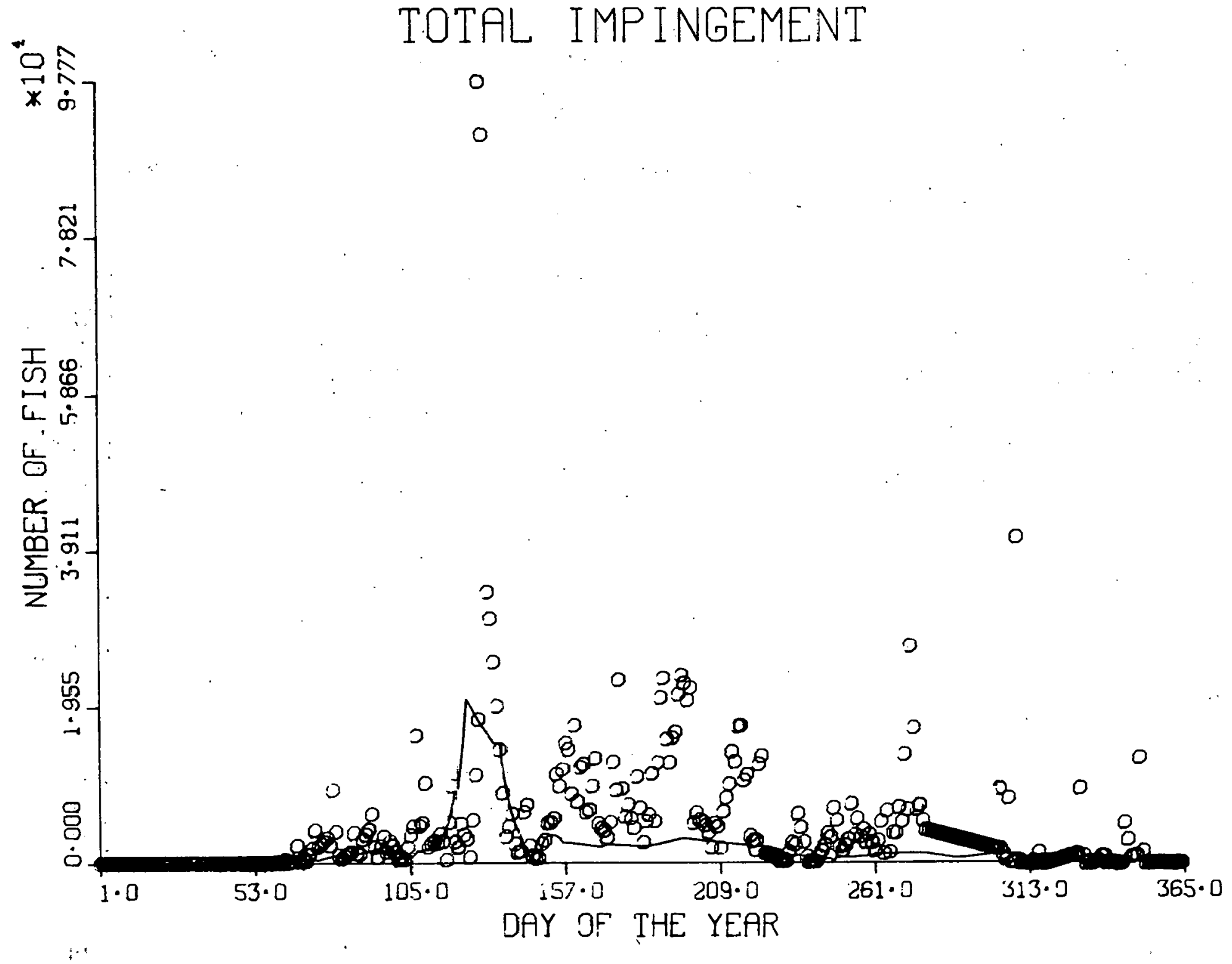

Fig. 7. Predicted Impingement (solid line) for Case I and observed Impingement (circles) of Both Species at the Zion Station during 1974 (No. of fish/day). 


\section{ESTIMATED PROBABILITY \\ ALEWIFE}

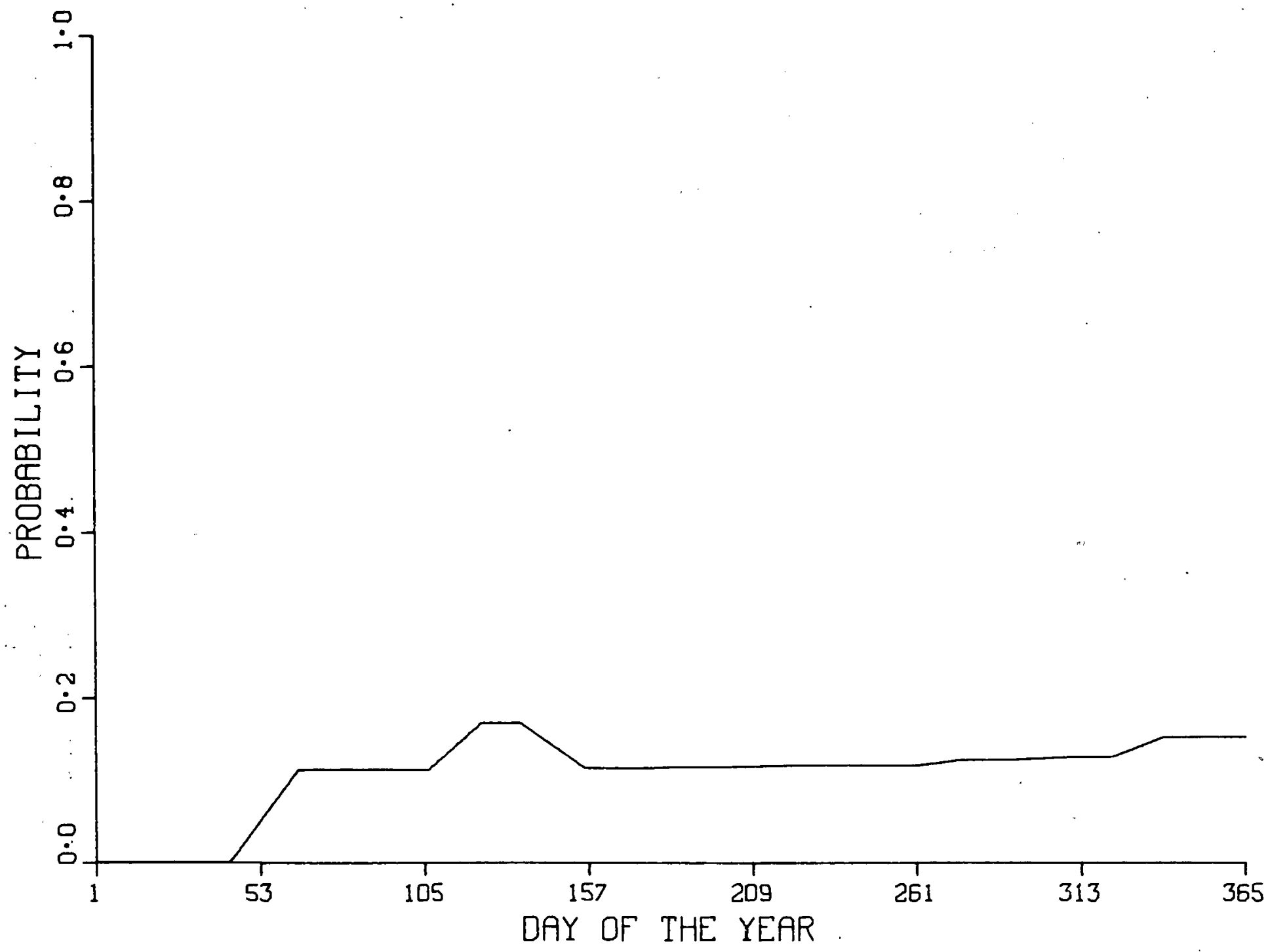

Fig. 8. The Risk of Impingement of Alewives According to the Probability Function under the Conditions of Case I. 
ESTIMATED PROBABILITY

SMELT

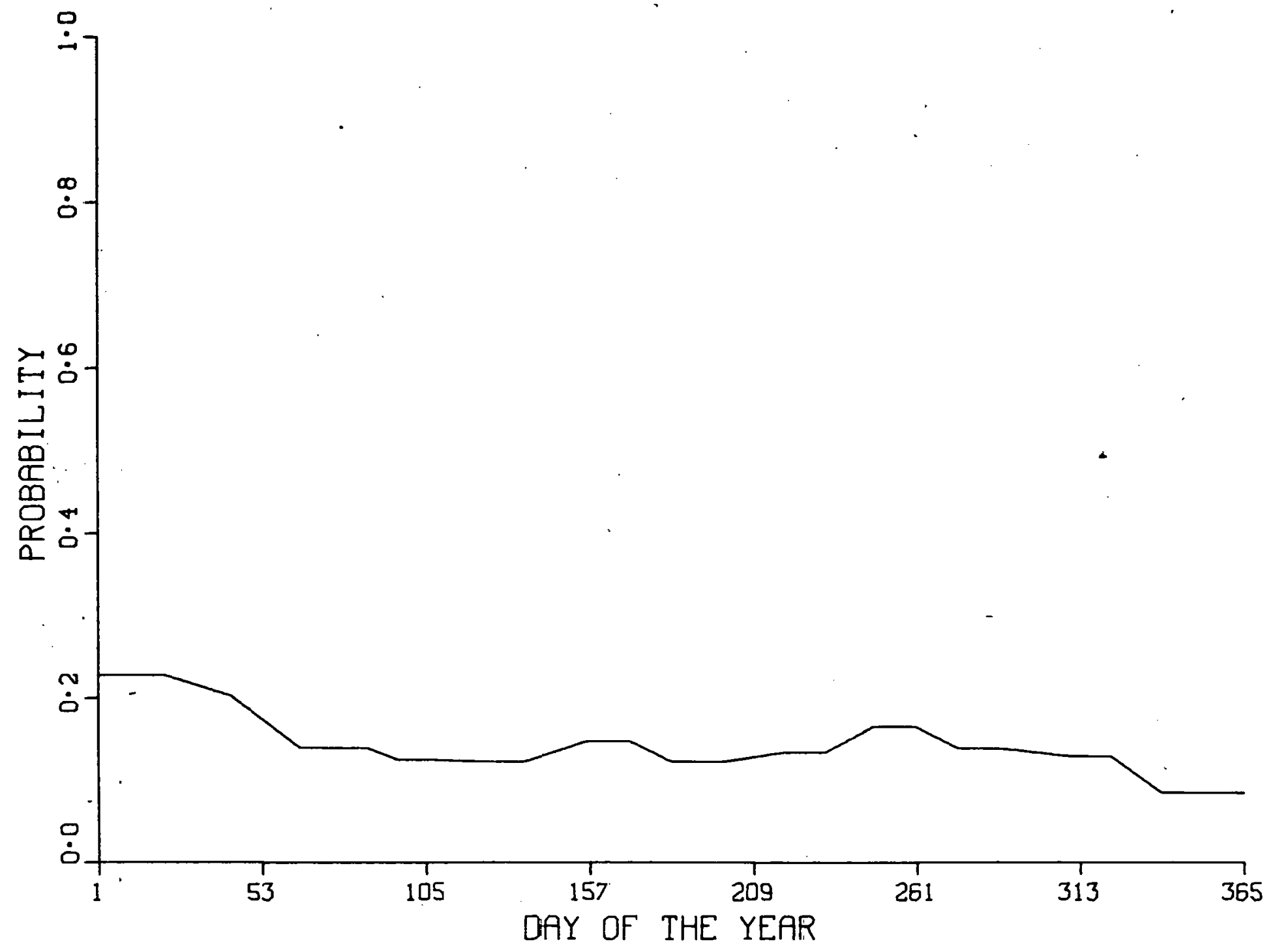

Fig. 5. The Risk of Impingement of Smelt According to the Probability Function under the Conditions of Case $I$. 
Table 5. Numerical Values for Fish Density and Probability of Impingement for Case I

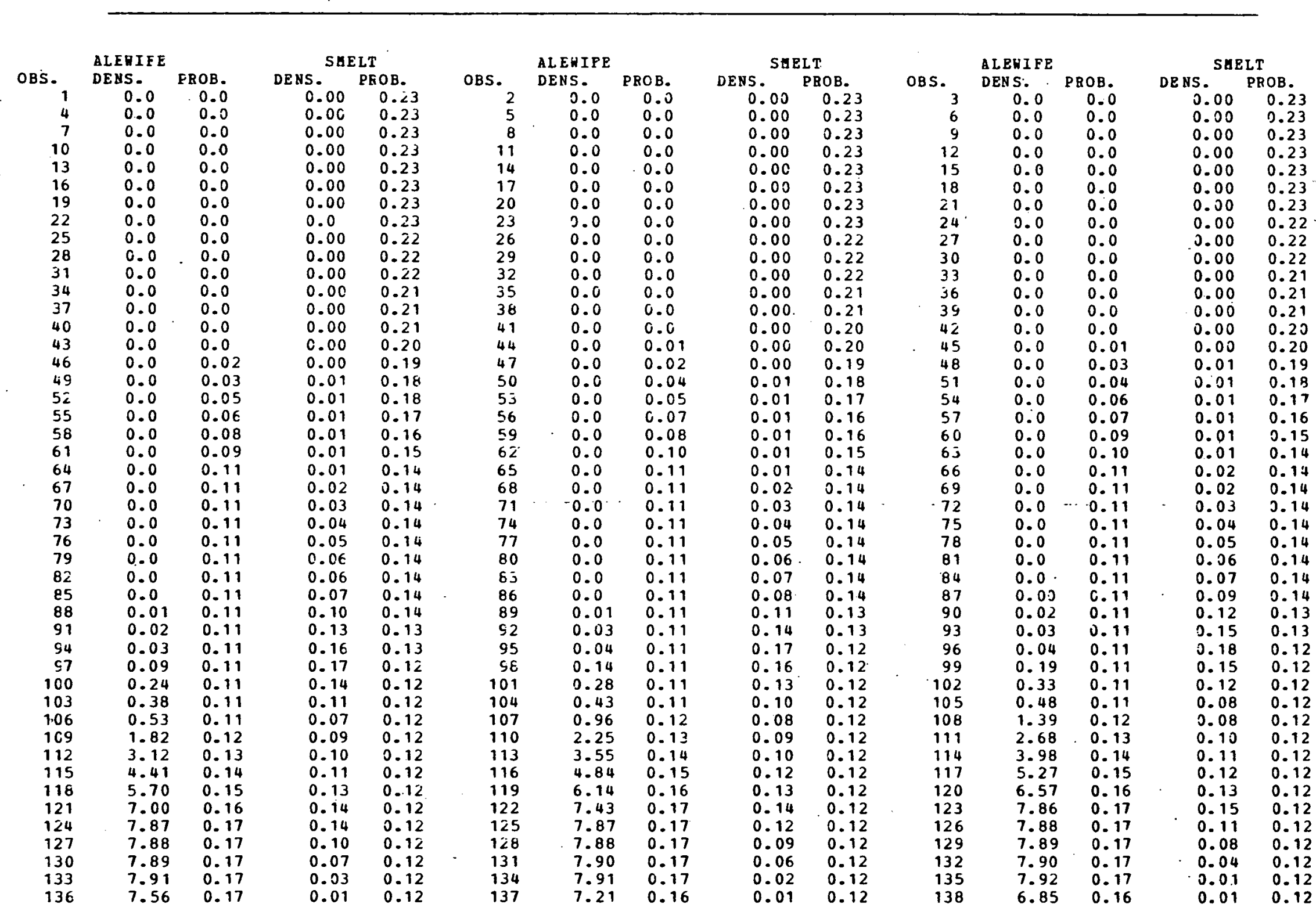


Table 5. Continued

\begin{tabular}{|c|c|c|c|c|c|c|c|c|c|c|c|c|c|c|}
\hline & ALEWIFE & PROR & \multicolumn{2}{|c|}{ SAELE } & \multicolumn{3}{|c|}{ ALEWIFE } & \multicolumn{2}{|c|}{ SHELT } & \multicolumn{3}{|c|}{ A LERIFE } & \multicolumn{2}{|c|}{ SEE T } \\
\hline ES. & $\begin{array}{r}\text { DENS: } \\
6: 49\end{array}$ & $\begin{array}{l}\text { PROE. } \\
0.16\end{array}$ & DENS. & $\begin{array}{c}\mathrm{PFOB} \\
0.13\end{array}$ & OBS. & JENS. & PROB. & DENS. & PROB. & OBS. & DENS. & PROB. & DENS. & PROB. \\
\hline $\begin{array}{l}139 \\
142\end{array}$ & 5.43 & $\begin{array}{l}0.15 \\
0.15\end{array}$ & 0.01 & $\begin{array}{l}0.13 \\
0.13\end{array}$ & $\begin{array}{l}140 \\
143\end{array}$ & 6.14 & 0.16 & 0.01 & 0.13 & 141 & 5.78 & 0.15 & 0.01 & 0.13 \\
\hline 145 & 4.36 & 0.14 & 0.01 & 0.13 & $\begin{array}{l}143 \\
146\end{array}$ & 5.07 & 0.15 & 0.01 & 0.13 & 144 & 4.72 & 0.15 & 0.01 & 0.13 \\
\hline 148 & 3.29 & 0.14 & 0.00 & 0.14 & $\begin{array}{l}146 \\
149\end{array}$ & 4.01 & 0.14 & 0.00 & 0.14 & 147 & 3.65 & 0.14 & 0.00 & 0.14 \\
\hline 151 & 2.23 & 0.13 & 0.00 & $0-14$ & $\begin{array}{l}149 \\
152\end{array}$ & 2.94 & 0.13 & 0.00 & 0.74 & 150 & 2.58 & 0.13 & 0.00 & 0.14 \\
\hline 154 & 1.16 & 0.12 & 0.00 & 0.15 & $\begin{array}{l}152 \\
155\end{array}$ & 1.87 & 0.12 & 0.00 & 0.14 & 153 & 1.52 & 0.12 & 0.00 & 0.14 \\
\hline 157 & 0.46 & 0.11 & 0.00 & 0.15 & $\begin{array}{l}155 \\
158\end{array}$ & 0.80 & 0.12 & 0.00 & 0.15. & 156 & 0.45 & 0.11 & 0.0 & 0.15 \\
\hline 160 & 0.49 & 0.11 & $\begin{array}{l}0.0 \\
0.0\end{array}$ & 0.15 & $\begin{array}{l}158 \\
161\end{array}$ & 0.47 & 0.91 & 0.0 & 0.15. & 159 & 0.48 & 0.11 & 0.0 & 0.15 \\
\hline 163 & 0.52 & 0.11 & $\begin{array}{l}0.0 \\
0.0\end{array}$ & 0.15 & $\begin{array}{l}161 \\
164\end{array}$ & 0.50 & 0.11 & 0.0 & 0.15 & 162 & 0.51 & 0.11 & 0.0 & 0.15 \\
\hline 166 & 0.56 & 0.11 & 0.0 & 0.15 & $\begin{array}{l}164 \\
167\end{array}$ & 0.53 & 0.11 & 0.0 & 0.15 & 165 & 0.55 & 0.11 & 0.0 & 0.15 \\
\hline 169 & 0.59 & 0.11 & 0.0 & 0.15 & 170 & 0.57 & 0.11 & 0.00 & $\begin{array}{l}0.75 \\
0.15\end{array}$ & $\begin{array}{l}168 \\
171\end{array}$ & $\begin{array}{l}0.58 \\
0.56\end{array}$ & $\begin{array}{l}0.11 \\
0.11\end{array}$ & 0.0 & $\begin{array}{l}0.15 \\
0.14\end{array}$ \\
\hline 172 & 0.54 & 0.11 & 0.00 & 0.14 & 173 & 0.53 & 0.11 & 0.00 & 0.14 & 174 & 0.51 & 0.11 & 0.00 & 0.14 \\
\hline 175 & 0.50 & 0.11 & 0.00 & 0.14 & 176 & 0.48 & 0.11 & 0.00 & 0.13 & 177 & 0.47 & 0.11 & 0.00 & 0.13 \\
\hline 178 & 0.45 & 0.12 & 0.00 & 0.13 & 179 & 0.44 & 0.12 & 0.00 & 0.13 & 180 & 0.42 & 0.12 & 0.00 & 0.13 \\
\hline 181 & 0.41 & 0.12 & 0.00 & 0.12 & 182 & 0.39 & 0.12 & 0.00 & 0.12 & 183 & 0.38 & 0.12 & 0.00 & 0.12 \\
\hline 184 & 0.44 & 0.12 & 0.00 & 0.12 & 185 & 0.50 & 0.12 & 0.00 & 0.12 & 186 & 0.56 & 0.12 & 0.00 & 0.12 \\
\hline 187 & 0.63 & 0.12 & 0.00 & 0.12 & 188 & 0.69 & 0.12 & 0.00 & 0.12 & 189 & 0.75 & 0.12 & 0.00 & 0.12 \\
\hline 150 & 0.81 & 0.12 & 0.00 & 0.12 & 191 & 0.87 & 0.12 & 0.00 & 0.12 & 192 & 0.93 & 0.12 & 0.00 & 0.12 \\
\hline 193 & 0.99 & 0.12 & 0.00 & 0.12 & 194 & 1.05 & 0.12 & 0.00 & 0.12 & 195 & 1.12 & 0.12 & 0.00 & 0.12 \\
\hline $1 \subseteq 6$ & 1.18 & 0.12 & 0.00 & 0.12 & 197 & 1.24 & 0.12 & 0.0 & 0.12 & 198 & 1.21 & 0.12 & 0.0 & 0.12 \\
\hline 199 & 1.18 & 0.12 & 0.0 & 0.12 & 200 & 1.15 & $0.1 \ddot{z}$ & 0.0 & 0.12 & 201 & 1.12 & 0.12 & 0.0 & 0.12 \\
\hline 202 & 1.10 & 0.12 & 0.0 & 0.12 & 203 & 1.07 & 0.12 & 0.0 & 0.12 & 204 & 1.04 & 0.12 & 0.0 & 0.13 \\
\hline 205 & 1.01 & 0.12 & 0.0 & 0.13 & 206 & 0.98 & 0.12 & 0.0 & 0.13 & 207 & 0.95 & 0.12 & 0.0 & 0.13 \\
\hline 208 & 0.93 & 0.12 & 0.0 & 0.13 & 209 & 0.90 & 0.12 & 0.0 & 0.13 & 210 & 0.87 & 0.12 & 0.0 & 0.13 \\
\hline 211 & 0.84 & 0.12 & 0.0 & 0.13 & $<12$ & 0.81 & 0.12 & 0.0 & 0.13 & 213 & 0.78 & 0.12 & 0.0 & 0.13 \\
\hline 214 & 0.75 & 0.12 & 0.0 & 0.13 & 215 & 0.73 & 0.12 & 0.0 & 0.13 & 216 & 0.70 & 0.12 & 0.0 & 0.13 \\
\hline 217 & 0.67 & 0.12 & 0.0 & 0.13 & $<18$ & 0.64 & 0.12 & 0.0 & 0.13 & 219 & 0.61 & 0.12 & 0.0 & 0.13 \\
\hline 220 & 0.61 & 0.12 & 0.0 & 0.13 & 221 & 0.61 & 0.12 & 0.0 & 0.13 & 222 & 0.60 & 0.12 & 0.0 & 0.13 \\
\hline 223 & 0.60 & 0.12 & 0.0 & 0.13 & $2<4$ & 0.60 & 0.12 & 0.0 & 0.13 & $2<5$ & 0.59 & 0.12 & 0.0 & 0.13 \\
\hline 226 & 0.59 & 0.12 & 0.0 & 0.13 & 227 & 0.59 & 0.12 & 0.0 & 0.13 & 228 & 0.59 & 0.12 & 0.0 & 0.13 \\
\hline 229 & 0.58 & 0.12 & 0.0 & $0.1 \mathrm{j}$ & 230 & 0.58 & 0.12 & 0.0 & 0.13 & 231 & 0.58 & 0.12 & 0.0 & 0.13 \\
\hline 232 & 0.58 & 0.12 & 0.0 & 0.13 & 233 & 0.54 & 0.12 & 0.0 & 0.14 & 234 & 0.50 & 0.12 & 0.0 & 0.14 \\
\hline 235 & $0.4 \epsilon$ & 0.12 & 0.0 & 0.14 & 236 & 0.42 & 0.12 & 0.0 & 0.14 & 237 & 0.38 & 0.12 & 0.0 & 0.14 \\
\hline 238 & 0.35 & 0.12 & 0.0 & 0.15 & $23 \mathrm{~s}$ & 0.31 & 0.12 & 0.0 & 0.15 & 240 & 0.27 & 0.12 & 0.0 & 0.15 \\
\hline 241 & 0.23 & 0.12 & 0.0 & 0.15 & 242 & 0.19 & 0.12 & 0.0 & $0.15^{\circ}$ & 243 & 0.15 & 0.12 & 0.0 & 0.16 \\
\hline 244 & 0.12 & 0.12 & 0.0 & 0.16 & 245 & 0.08 & $0.1 \overline{2}$ & 0.0 & 0.16 & 246 & 0.04 & 0.12 & 0.0 & 0.16 \\
\hline 247 & 0.0 & 0.12 & 0.0 & 0.17 & 248 & 0.00 & 0.12 & 0.0 & 0.17 & 249 & 0.00 & 0.12 & 0.0 & 0.17 \\
\hline 250 & 0.00 & 0.12 & 0.0 & 0.17 & 251 & 0.00 & 0.12 & 0.0 & 0.17 & 252 & 0.00 & 0.12 & 0.0 & 0.17 \\
\hline 253 & 0.00 & 0.12 & 0.0 & 0.17 & 254 & 0.00 & 0.12 & 0.0 & 0.17 & 255 & 0.00 & 0.12 & 0.0 & 0.17 \\
\hline 256 & $0.0 \mathrm{G}$ & 0.12 & 0.0 & 0.17 & 257 & 0.00 & 0.12 & 0.0 & 0.17 & 258 & 0.00 & 0.12 & 0.0 & 0.17 \\
\hline 259 & 0.00 & 0.12 & 0.0 & 0.17 & $26 \mathrm{C}$ & 0.00 & 0.12 & 0.0 & 0.17 & 261 & 0.00 & 0.12 & 0.00 & 0.16 \\
\hline 262 & $0.0 \mathrm{C}$ & 0.12 & 0.01 & 0.16 & 263 & 0.01 & 0.12 & 0.01 & 0.16 & 264 & 0.01 & 0.12 & 0.02 & 0.16 \\
\hline 265 & 0.01 & 0.12 & 0.02 & 0.16 & $26 \epsilon$ & 0.01 & 0.12 & 0.02 & 0.15 & 267 & 0.01 & 0.12 & 0.03 & 0.15 \\
\hline 268 & 0.01 & 0.12 & 0.03 & 0.15 & 265 & 0.01 & 0.12 & 0.04 & 0.15 & 270 & 0.01 & 0.12 & 0.04 & 0.15 \\
\hline 271 & 0.01 & 0.12 & 0.04 & 0.14 & 272 & 0.01 & 0.12 & 0.05 & 0.14 & 273 & 0.01 & 0.12 & 0.05 & 0.14 \\
\hline 274 & 0.01 & 0.13 & 0.06 & 0.14 & 275 & 0.02 & 0.13 & 0.05 & 0.14 & 276 & 0.02 & 0.13 & 0.05 & 0.14 \\
\hline
\end{tabular}


Table 5. Continued

\begin{tabular}{|c|c|c|c|c|c|c|c|c|c|c|c|c|c|c|}
\hline \multirow{4}{*}{ OES. } & \multicolumn{2}{|l|}{$A L E W I F E$} & \multicolumn{2}{|c|}{ SHELT } & \multicolumn{3}{|c|}{ ALEWIFE } & \multicolumn{2}{|c|}{ SMELT } & \multicolumn{3}{|c|}{ ALEHIFE } & \multicolumn{2}{|c|}{ SMELT } \\
\hline & DENS. & PROB. & DENS. & PROE. & OBS. & DENS. & PFOB. & DENS. & PROB. & OBS. & DENS. & PROB. & DENS. & PROB. \\
\hline & 0.03 & 0.13 & 0.04 & 0.14 & 278 & $0.04^{\circ}$ & 0.13 & 10.04 & 0.14 & 279 & 0.04 & 0.13 & 0.04 & 0.14 \\
\hline & 0.05 & $0.1 j$ & 0.03 & C.14 & 281 & 0.05 & 0.13 & 3.03 & 0.14 & 282 & 0.06 & 0.13 & 0.02 & 0.14 \\
\hline 283 & 0.07 & 0.13 & 0.02 & 0.14 & 284 & 0.07 & 0.13 & 0.02 & 0.14 & 285 & 0.08 & 0.13 & 0.01 & 0.14 \\
\hline 286 & 0.08 & 0.13 & 0.01 & 0.14 & 287 & 0.09 & 0.13 & 0.00 & 0.14 & 288 & 0.09 & 0.13 & 0.00 & 0.14 \\
\hline 289 & 0.09 & 0.13 & 0.00 & 0.14 & 290 & 0.08 & 0.13 & 0.00 & 0.14 & 291 & 0.08 & 0.13 & 0.00 & 0.14 \\
\hline $2 \varsigma_{2}$ & 0.08 & 0.13 & 0.00 & 0.14 & 293 & 0.08 & 0.13 & 0.00 & 0.14 & 294 & 0.07 & 0.13 & 0.00 & 0.13 \\
\hline $2 \subseteq 5$ & 0.07 & 0.13 & 0.00 & 0.13 & 296 & 0.07 & 0.13 & 0.00 & 2.13 & 297 & 0.07 & 0.13 & 0.00 & 0.13 \\
\hline 258 & 0.06 & 0.13 & 0.00 & 0.13 & 299 & 0.06 & 0.13 & 0.00 & 0.13 & 300 & 0.06 & 0.13 & 0.00 & 0.13 \\
\hline 301 & 0.06 & 0.13 & 0.00 & 0.13 & 302 & 0.05 & 0.13 & 0.00 & 0.13 & 303 & 0.05 & 0.13 & 0.00 & 0.13 \\
\hline 304 & 0.05 & 0.13 & 0.00 & 0.13 & 305 & 0.05 & 0.13 & 0.00 & 0.13 & 306 & 0.04 & 0.13 & 0.00 & 0.13 \\
\hline 307 & 0.04 & 0.13 & 0.00 & 0.13 & 308 & 0.04 & 0.13 & 0.00 & 0.13 & 309 & 0.04 & 0.13 & 0.00 & 0.13 \\
\hline 310 & 0.03 & $0.1 j$ & 0.0 & 0.13 & 311 & 0.03 & 0.13 & 0.0 & 0.13 & 312 & 0.03 & 0.13 & 0.0 & 0.13 \\
\hline 313 & 0.03 & 0.13 & 0.0 & 0.13 & 314 & 0.02 & 0.13 & 0.0 & 0.13 & 315 & 0.02 & 0.13 & 0.0 & 0.13 \\
\hline 316 & 0.02 & 0.13 & 0.0 & 0.13 & 317 & 0.02 & 0.13 & 0.0 & 0.13 & 318 & 0.01 & 0.13 & 0.0 & 0.13 \\
\hline 319 & 0.01 & 0.13 & 0.0 & 0.13 & 320 & 0.01 & 0.13 & 0.0 & 0.13 & 321 & 0.01 & 0.13 & 0.0 & 0.13 \\
\hline 322 & 0.00 & 0.13 & 0.0 & 0.13 & 323 & 0.0 & $0.1 \overline{3}$ & 0.0 & 0.13 & 324 & 0.0 & 0.13 & 0.00 & 0.12 \\
\hline 325 & 0.0 & 0.13 & 0.00 & 0.12 & 326 & 0.0 & 0.13 & 0.00 & 0.12 & 327 & 0.0 & 0.14 & 0.00 & 0.12 \\
\hline $3 \angle 8$ & 0.0 & 0.14 & 0.00 & 0.11 & 329 & 0.0 & 0.14 & 0.00 & 0.11 & 330 & 0.0 & 0.14 & 0.00 & 0.11 \\
\hline 331 & 0.0 & 0.14 & 0.00 & 0.11 & 332 & 0.0 & 0.14 & 0.00 & 0.10 & 333 & 0.0 & 0.14 & 0.00 & 0.10 \\
\hline 334 & 0.0 & 0.15 & 0.00 & 0.10 & 335 & 0.0 & 0.15 & 0.00 & 0.09 & 336 & 0.0 & 0.15 & 0.00 & 0.09 \\
\hline 337 & 0.0 & 0.15 & 0.00 & 0.09 & 338 & 0.0 & 0.15 & 0.00 & 0.09 & 339 & 0.0 & 0.15 & 0.00 & 0.38 \\
\hline 340 & 0.0 & 0.15 & 0.00 & 0.08 & $3+1$ & 0.0 & 0.15 & 0.00 & 0.08 & 342 & 0.0 & 0.15 & 0.00 & 0.08 \\
\hline 343 & 0.0 & 0.15 & 0.00 & 0.08 & $3 \div 4$ & 0.0 & 0.15 & 0.00 & 0.08 & 345 & 0.0 & 0.15 & 0.00 & 0.08 \\
\hline 346 & 0.0 & 0.15 & 0.00 & 0.08 & $3 \div 7$ & 0.0 & 0.15 & 0.00 & 0.08 & 348 & 0.0 & 0.15 & 0.00 & 0.08 \\
\hline 349 & 0.0 & 0.15 & 0.00 & 0.08 & 350 & 0.0 & 0.15 & 0.00 & 0.08 & 351 & 0.0 & 0.15 & 0.00 & 0.09 \\
\hline 352 & 0.0 & 0.15 & 0.00 & 0.08 & 353 & 0.0 & 0.15 & 0.00 & 0.08 & 354 & 0.0 & 0.15 & 0.00 & 0.03 \\
\hline 355 & 0.0 & 0.15 & 0.00 & 0.08 & 356 & 0.0 & 0.15 & 0.00 & 0.08 & 357 & 0.0 & 0.15 & 0.00 & 0.08 \\
\hline 358 & 0.0 & 0.15 & 0.00 & 0.08 & 359 & 0.0 & 0.15 & 0.00 & 0.08 & 360 & C. 0 & 0.15 & 0.00 & 0.09 \\
\hline 361 & 0.0 & 0.15 & $\begin{array}{l}0.00 \\
0.00\end{array}$ & 0.08 & $\begin{array}{l}362 \\
365\end{array}$ & $\begin{array}{l}0.0 \\
0.0\end{array}$ & $\begin{array}{l}0.15 \\
0.15\end{array}$ & $\begin{array}{l}0.00 \\
0.00\end{array}$ & $\begin{array}{l}0.08 \\
0.38\end{array}$ & 363 & 0.0 & 0.15 & 0.00 & 0.08 \\
\hline 364 & 0.0 & 0.15 & 0.00 & 0.08 & 365 & 0.0 & 0.15 & $0.0 \mathrm{C}$ & 0.38 & & & & & \\
\hline
\end{tabular}


Table 6. Daily Fish-Impingement Pedictions Calculated According to Case-II Specifications

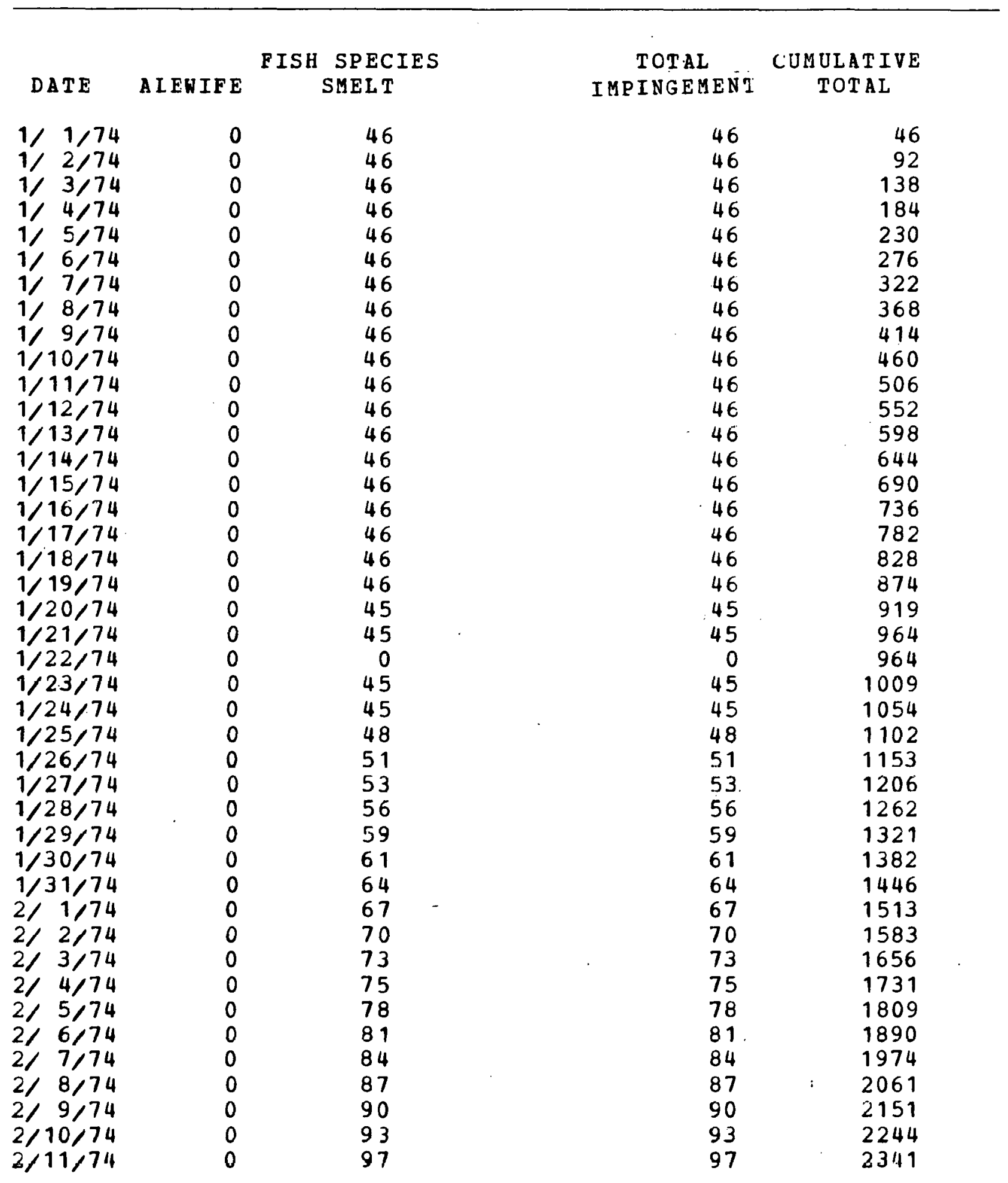


Table 6. Continued

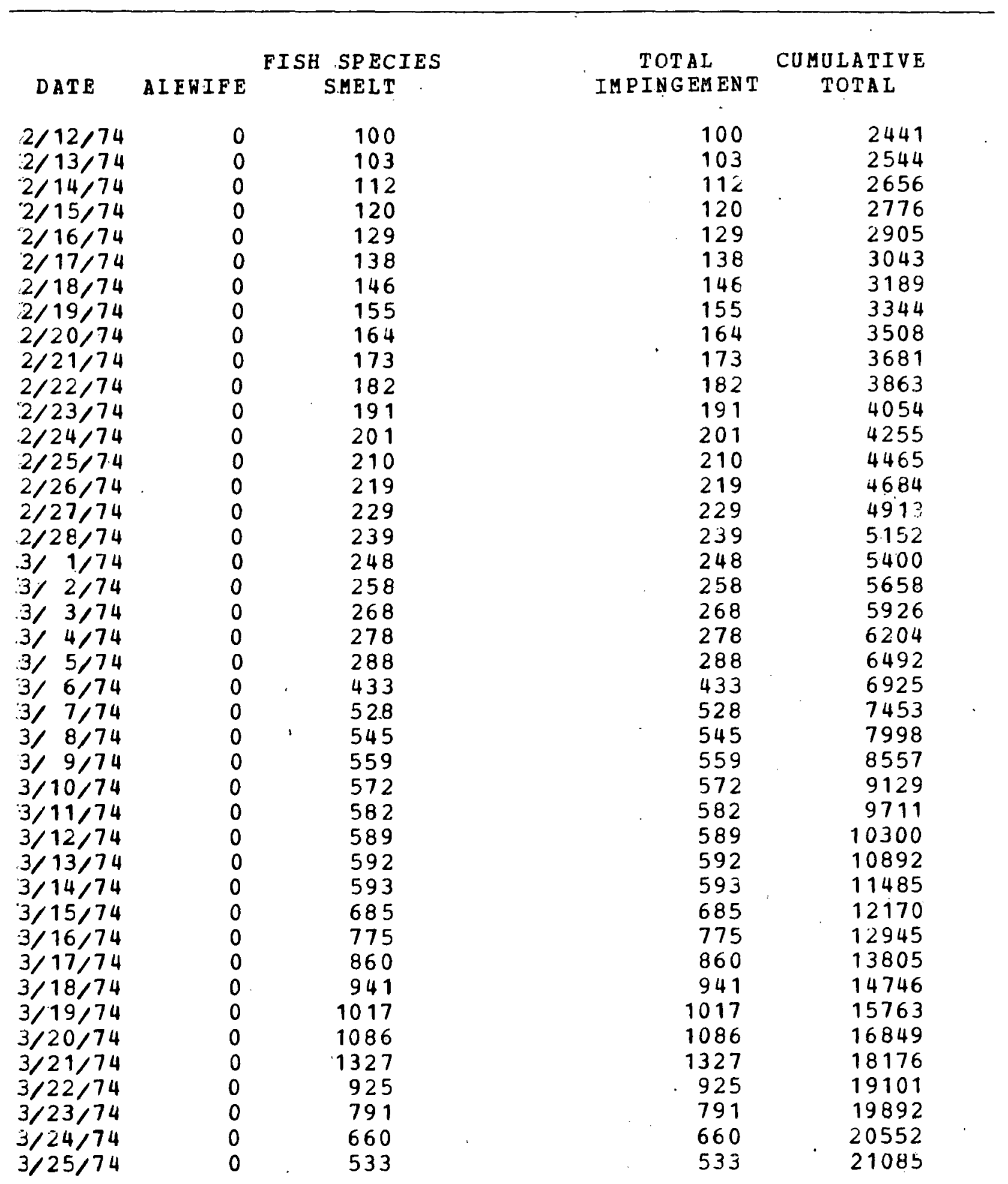


Table 6. Continued

\begin{tabular}{|c|c|c|c|c|}
\hline DATE & A LEW IFE & $\begin{array}{c}\text { FISH }{ }_{\text {SMELT }}^{\text {SPECIES }} \\
\text { SME }\end{array}$ & $\begin{array}{c}\text { TOTAL } \\
\text { IMPINGEMENT }\end{array}$ & $\begin{array}{c}\text { CUMULATIVE } \\
\text { TOTAL }\end{array}$ \\
\hline $\begin{array}{l}3 / 26 / 74 \\
3 / 27 / 74 \\
3 / 28 / 74 \\
3 / 29 / 74 \\
3 / 30 / 74 \\
3 / 31 / 74 \\
4 / 1 / 74 \\
4 / 2 / 74 \\
4 / 3 / 74 \\
4 / 4 / 74 \\
4 / 5 / 74 \\
4 / 6 / 74 \\
4 / 7 / 74 \\
4 / 8 / 74 \\
4 / 9 / 74 \\
4 / 10 / 74 \\
4 / 11 / 74 \\
4 / 12 / 74 \\
4 / 13 / 74 \\
4 / 14 / 74 \\
4 / 15 / 74 \\
4 / 16 / 74 \\
4 / 17 / 74 \\
4 / 18 / 74 \\
4 / 19 / 74 \\
4 / 20 / 711 \\
4 / 21 / 71 \\
4 / 22 / 74 \\
4 / 23 / 74 \\
4 / 24 / 74 \\
4 / 25 / 74 \\
4 / 26 / 74 \\
4 / 27 / 74 \\
4 / 28 / 74 \\
4 / 29 / 74 \\
4 / 30 / 74 \\
5 / 1 / 74 \\
5 / 2 / 74 \\
5 / 3 / 74 \\
5 / 4 / 74 \\
5 / 5 / 74 \\
5 / 6 / 74\end{array}$ & $\begin{array}{r}0 \\
0 \\
199 \\
202 \\
204 \\
205 \\
206 \\
206 \\
206 \\
205 \\
204 \\
87 \\
97 \\
103 \\
103 \\
97 \\
143 \\
192 \\
246 \\
304 \\
367 \\
504 \\
815 \\
1037 \\
1315 \\
1660 \\
2086 \\
2608 \\
3245 \\
4013 \\
4929 \\
6257 \\
7941 \\
10073 \\
12773 \\
15386 \\
17835 \\
25549 \\
28688 \\
38359 \\
38379 \\
38343\end{array}$ & $\begin{array}{l}410 \\
1098 \\
1232 \\
1394 \\
1574 \\
1773 \\
1992 \\
2232 \\
2494 \\
2780 \\
3091 \\
1471 \\
1428 \\
1304 \\
1126 \\
914 \\
1156 \\
1343 \\
1483 \\
1582 \\
1648 \\
1950 \\
2554 \\
2631 \\
2700 \\
2758 \\
2806 \\
2840 \\
2860 \\
2863 \\
2846 \\
2925 \\
3005 \\
3085 \\
3167 \\
3087 \\
3621 \\
4199 \\
3816 \\
4498 \\
3967 \\
3493\end{array}$ & $\begin{array}{l}410 \\
1098 \\
1431 \\
1596 \\
1778 \\
1978 \\
2198 \\
2438 \\
2700 \\
2985 \\
3295 \\
1558 \\
1525 \\
1407 \\
1229 \\
1011 \\
1299 \\
1535 \\
1729 \\
1886 \\
2015 \\
2454 \\
3369 \\
3668 \\
4015 \\
4418 \\
4892 \\
5440 \\
6105 \\
6876 \\
7775 \\
9182 \\
10946 \\
13158 \\
15940 \\
18473 \\
21456 \\
23748 \\
32504 \\
42857 \\
42346 \\
41836\end{array}$ & $\begin{array}{r}21495 \\
22593 \\
24024 \\
25620 \\
27398 \\
29376 \\
31574 \\
34012 \\
36712 \\
39697 \\
42992 \\
44550 \\
46075 \\
47482 \\
48711 \\
49722 \\
51021 \\
52556 \\
54285 \\
56171 \\
58186 \\
60640 \\
64009 \\
67677 \\
71692 \\
76110 \\
81002 \\
06450 \\
92555 \\
99431 \\
107206 \\
116388 \\
127334 \\
140492 \\
156432 \\
174905 \\
196361 \\
226109 \\
258613 \\
301470 \\
343816 \\
385652\end{array}$ \\
\hline
\end{tabular}


Table 6. Continued

\begin{tabular}{|c|c|c|c|c|}
\hline DATE & A IEWIFE & $\begin{array}{c}\text { FISH } \text { SPECIES } \\
\text { SMELT }\end{array}$ & $\begin{array}{c}\text { TCTAL } \\
\text { IMPINGEMENT }\end{array}$ & $\begin{array}{c}\text { CUMULATIVE } \\
\text { TOTAL }\end{array}$ \\
\hline $\begin{array}{l}5 / 7 / 74 \\
5 / 8 / 74 \\
5 / 9 / 74 \\
5 / 10 / 74 \\
5 / 11 / 74 \\
5 / 12 / 74 \\
5 / 13 / 74 \\
5 / 14 / 74 \\
5 / 15 / 74 \\
5 / 16 / 74 \\
5 / 17 / 74 \\
5 / 18 / 74 \\
5 / 19 / 74 \\
5 / 20 / 74 \\
5 / 21 / 74 \\
5 / 22 / 74 \\
5 / 23 / 74 \\
5 / 24 / 74 \\
5 / 25 / 74 \\
5 / 26 / 74 \\
5 / 27 / 74 \\
5 / 28 / 74 \\
5 / 29 / 74 \\
5 / 30 / 74 \\
5 / 31 / 74 \\
6 / 1 / 74 \\
6 / 2 / 74 \\
6 / 3 / 74 \\
6 / 4 / 74 \\
6 / 5 / 74 \\
6 / 6 / 74 \\
6 / 7 / 74 \\
6 / 8 / 74 \\
6 / 9 / 74 \\
6 / 10 / 74 \\
6 / 11 / 74 \\
6 / 12 / 74 \\
6 / 13 / 74 \\
6 / 14 / 74 \\
6 / 15 / 74 \\
6 / 16 / 74 \\
6 / 17 / 74\end{array}$ & $\begin{array}{r}38250 \\
38100 \\
37892 \\
37626 \\
37300 \\
36916 \\
36472 \\
36574 \\
36677 \\
31314 \\
25313 \\
20462 \\
16540 \\
13370 \\
10808 \\
8737 \\
5698 \\
3526 \\
1995 \\
936 \\
221 \\
179 \\
7158 \\
9727 \\
11093 \\
11613 \\
11555 \\
11116 \\
10439 \\
9629 \\
9176 \\
8613 \\
8513 \\
8409 \\
8299 \\
8185 \\
8066 \\
7941 \\
7812 \\
7677 \\
7536 \\
7390\end{array}$ & $\begin{array}{r}2560 \\
2247 \\
1970 \\
1724 \\
1507 \\
1314 \\
1145 \\
1012 \\
894 \\
940 \\
935 \\
930 \\
926 \\
921 \\
916 \\
912 \\
732 \\
557 \\
388 \\
224 \\
65 \\
65 \\
197 \\
329 \\
462 \\
595 \\
729 \\
863 \\
998 \\
0 \\
0 \\
0 \\
0 \\
0 \\
0 \\
0 \\
0 \\
0 \\
0 \\
0 \\
0 \\
0\end{array}$ & $\begin{array}{r}40810 \\
40347 \\
39862 \\
39350 \\
38807 \\
38230 \\
37617 \\
37586 \\
37571 \\
32254 \\
26248 \\
21392 \\
17466 \\
14291 \\
11724 \\
9649 \\
6430 \\
4083 \\
2383 \\
1160 \\
286 \\
244 \\
7355 \\
10056 \\
11555 \\
12208 \\
12284 \\
11979 \\
11437 \\
9629 \\
9176 \\
8613 \\
8513 \\
8409 \\
8299 \\
8185 \\
8066 \\
7941 \\
7812 \\
7677 \\
7536 \\
7390\end{array}$ & $\begin{array}{r}426462 \\
466809 \\
506671 \\
546021 \\
584828 \\
623058 \\
660675 \\
698261 \\
735832 \\
768086 \\
794334 \\
815726 \\
833192 \\
847483 \\
859207 \\
868856 \\
875286 \\
879369 \\
881752 \\
882912 \\
883198 \\
883442 \\
890797 \\
900853 \\
912408 \\
924616 \\
936900 \\
948879 \\
960316 \\
969945 \\
979121 \\
987734 \\
996247 \\
1004656 \\
1012955 \\
1021140 \\
1029206 \\
1037147 \\
1044959 \\
1052636 \\
1060172 \\
1067562\end{array}$ \\
\hline
\end{tabular}


Table 6. Continued

\begin{tabular}{|c|c|c|c|c|}
\hline DATE & A IEWIFE & 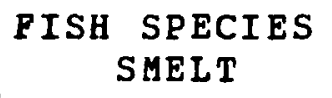 & $\begin{array}{c}\text { TOTAL } \\
\text { IMPINGEMENT }\end{array}$ & $\begin{array}{c}\text { CUMULATIVE } \\
\text { TOTAL }\end{array}$ \\
\hline $\begin{array}{l}6 / 18 / 74 \\
6 / 19 / 74 \\
6 / 20 / 74 \\
6 / 21 / 74 \\
6 / 22 / 74 \\
6 / 23 / 74 \\
6 / 24 / 74 \\
6 / 25 / 74 \\
6 / 26 / 74 \\
6 / 27 / 74 \\
6 / 28 / 74 \\
6 / 29 / 74 \\
6 / 30 / 74 \\
7 / 1 / 74 \\
7 / 2 / 74 \\
7 / 3 / 74 \\
7 / 7 / 74 \\
7 / 7 / 74 \\
7 / 6 / 74 \\
7 / 7 / 74 \\
7 / 7 / 74 \\
7 / 7 / 74 \\
7 / 10 / 74 \\
7 / 11 / 74 \\
7 / 12 / 74 \\
7 / 13 / 74 \\
7 / 14 / 74 \\
7 / 15 / 74 \\
7 / 16 / 74 \\
7 / 77 / 74 \\
7 / 18 / 74 \\
7 / 19 / 74 \\
7 / 20 / 74 \\
7 / 21 / 74 \\
7 / 22 / 74 \\
7 / 23 / 74 \\
7 / 24 / 74 \\
7 / 25 / 74 \\
7 / 26 / 74 \\
7 / 27 / 74 \\
7 / 28 / 74 \\
7 / 29 / 74\end{array}$ & $\begin{array}{r}7856 \\
8283 \\
8497 \\
8706 \\
8911 \\
9111 \\
9307 \\
9499 \\
9687 \\
9870 \\
9324 \\
9165 \\
9008 \\
8854 \\
8701 \\
8950 \\
9205 \\
9468 \\
9736 \\
10012 \\
10295 \\
10584 \\
11904 \\
13307 \\
14798 \\
16382 \\
18065 \\
19850 \\
23922 \\
18183 \\
18292 \\
18392 \\
18484 \\
18567 \\
18642 \\
18710 \\
18769 \\
18821 \\
16216 \\
15195 \\
14205 \\
13243\end{array}$ & 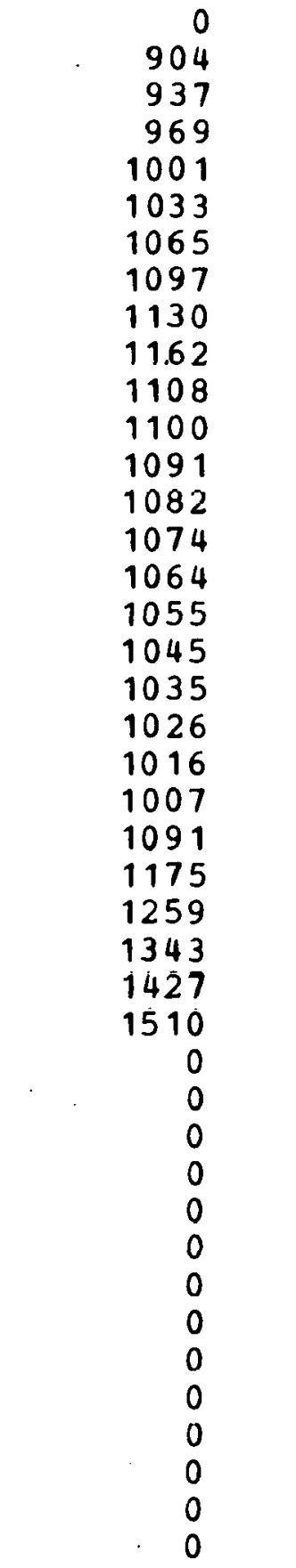 & $\begin{array}{r}7856 \\
9187 \\
9434 \\
9675 \\
9912 \\
10144 \\
10372 \\
10596 \\
10817 \\
11032 \\
10432 \\
10265 \\
10099 \\
9936 \\
9775 \\
10014 \\
10260 \\
10513 \\
10771 \\
11038 \\
11311 \\
11591 \\
12995 \\
14482 \\
16057 \\
17725 \\
19492 \\
21360 \\
23922 \\
18183 \\
18292 \\
18392 \\
18484 \\
18567 \\
18642 \\
18710 \\
18769 \\
18821 \\
16216 \\
15195 \\
14205 \\
13243\end{array}$ & $\begin{array}{l}1075418 \\
1084605 \\
1094039 \\
1103714 \\
1113626 \\
1123770 \\
1134142 \\
1144738 \\
1155555 \\
1166587 \\
1177019 \\
1187284 \\
1197383 \\
1207319 \\
1217094 \\
1227108 \\
1237368 \\
1247881 \\
1258652 \\
1269690 \\
1281001 \\
1292592 \\
1305587 \\
1320069 \\
1336126 \\
1353851 \\
1373343 \\
1394703 \\
1418625 \\
1436808 \\
1455100 \\
1473492 \\
1491976 \\
1510543 \\
1529185 \\
1547895 \\
1566664 \\
1585485 \\
1601701 \\
1616896 \\
1631101 \\
1644344\end{array}$ \\
\hline
\end{tabular}


Table 6. Continued

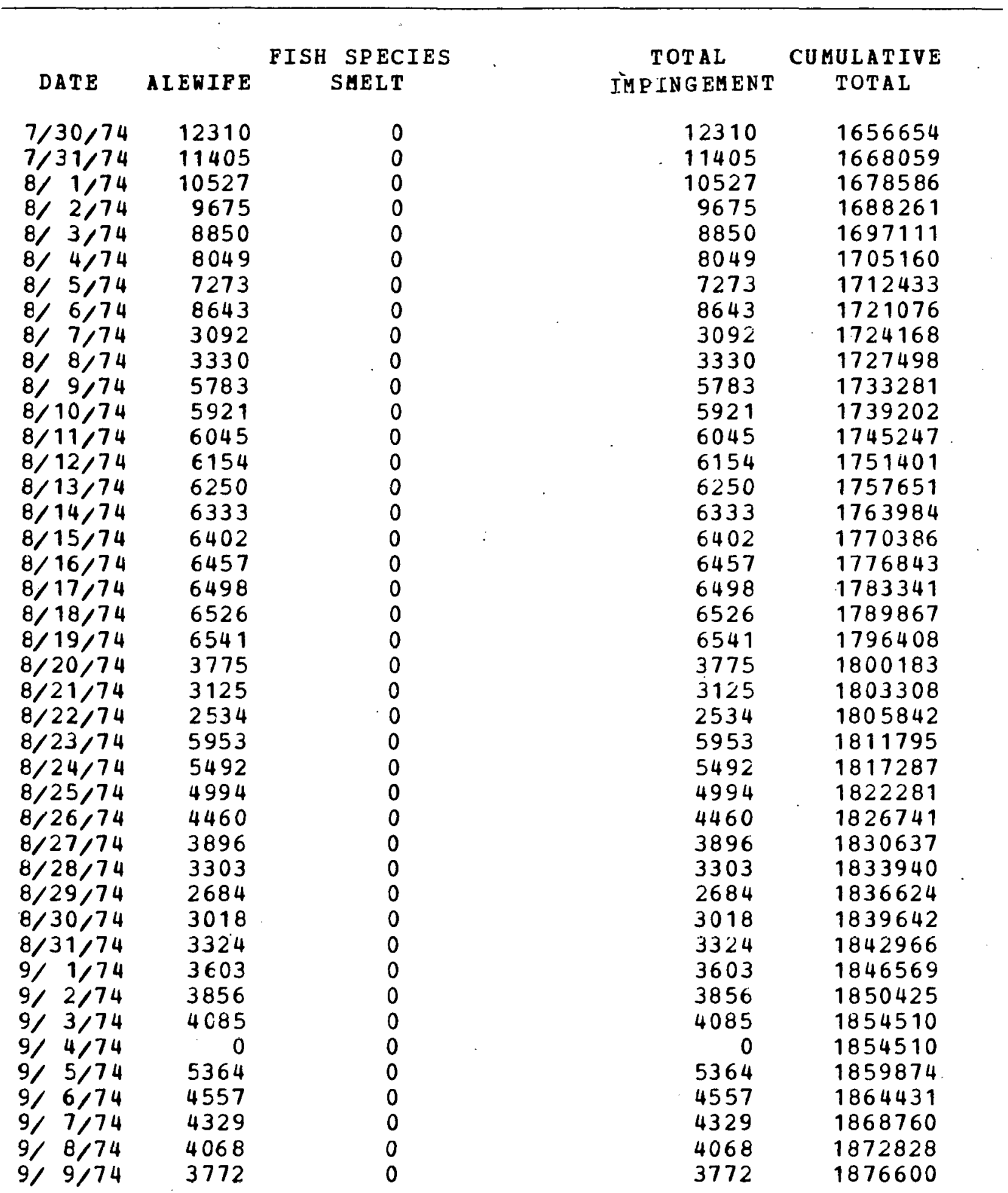


Table 6. Continued

\begin{tabular}{|c|c|c|c|c|}
\hline DATE & AIEUIFE & $\begin{array}{c}\text { PISH } \text { SPECIES } \\
\text { SHELT }\end{array}$ & $\begin{array}{c}\text { TOTAL } \\
\text { IMPINGEMENT }\end{array}$ & $\begin{array}{c}\text { CUMULATIVE } \\
\text { TOTAL }\end{array}$ \\
\hline $\begin{array}{c}9 / 10 / 74 \\
9 / 11 / 74 \\
9 / 12 / 74 \\
9 / 13 / 74 \\
9 / 14 / 74 \\
9 / 15 / 74 \\
9 / 16 / 74 \\
9 / 17 / 74 \\
9 / 18 / 74 \\
9 / 19 / 74 \\
9 / 20 / 74 \\
9 / 21 / 74 \\
9 / 22 / 74 \\
9 / 23 / 74 \\
9 / 24 / 74 \\
9 / 25 / 74 \\
9 / 26 / 74 \\
9 / 27 / 74 \\
9 / 28 / 74 \\
9 / 29 / 74 \\
9 / 30 / 74 \\
10 / 1 / 74 \\
10 / 2 / 74 \\
10 / 3 / 74 \\
10 / 4 / 74 \\
10 / 5 / 74 \\
10 / 6 / 74 \\
10 / 7 / 74 \\
10 / 8 / 74 \\
10 / 9 / 74 \\
10 / 10 / 74 \\
10 / 11 / 74 \\
10 / 12 / 74 \\
10 / 13 / 74 \\
10 / 14 / 74 \\
10 / 15 / 74 \\
10 / 16 / 74 \\
10 / 17 / 74 \\
10 / 18 / 74 \\
10 / 19 / 74 \\
10 / 20 / 74 \\
10 / 21 / 74\end{array}$ & $\begin{array}{l}3443 \\
3081 \\
2685 \\
3303 \\
3967 \\
4677 \\
5433 \\
4818 \\
4639 \\
5039 \\
4969 \\
4898 \\
4828 \\
4757 \\
4686 \\
4615 \\
4544 \\
4473 \\
4402 \\
4331 \\
4260 \\
4189 \\
4131 \\
4073 \\
3921 \\
3766 \\
3608 \\
3447 \\
3283 \\
3116 \\
2946 \\
2772 \\
2596 \\
2416 \\
2233 \\
2173 \\
2112 \\
2266 \\
2416 \\
2563 \\
2707 \\
2847\end{array}$ & $\begin{array}{r}0 \\
0 \\
0 \\
0 \\
0 \\
0 \\
0 \\
0 \\
724 \\
821 \\
844 \\
868 \\
892 \\
917 \\
942 \\
968 \\
994 \\
1020 \\
1047 \\
1075 \\
1103 \\
1131 \\
1066 \\
1004 \\
924 \\
848 \\
777 \\
709 \\
645 \\
585 \\
529 \\
476 \\
426 \\
379 \\
335 \\
325 \\
316 \\
339 \\
361 \\
382 \\
404 \\
424\end{array}$ & $\begin{array}{l}3443 \\
3081 \\
2685 \\
3303 \\
3967 \\
4677 \\
5433 \\
4818 \\
5363 \\
5860 \\
5813 \\
5766 \\
5720 \\
5674 \\
5628 \\
5583 \\
5538 \\
5493 \\
5449 \\
5406 \\
5363 \\
5320 \\
5197 \\
5077 \\
4845 \\
4614 \\
4385 \\
4156 \\
3928 \\
3701 \\
3475 \\
3248 \\
3022 \\
2795 \\
2568 \\
2498 \\
2428 \\
2605 \\
2777 \\
2945 \\
3111 \\
3271\end{array}$ & $\begin{array}{l}1880043 \\
1883124 \\
1885809 \\
1889112 \\
1893079 \\
1897756 \\
1903189 \\
1908007 \\
1913370 \\
1919230 \\
1925043 \\
1930809 \\
1936529 \\
1942203 \\
1947831 \\
1953414 \\
1958952 \\
1964445 \\
1969894 \\
1975300 \\
1980663 \\
1985983 \\
1991180 \\
1996257 \\
2001102 \\
2005716 \\
2010101 \\
2014257 \\
2018185 \\
2021886 \\
2025361 \\
2028609 \\
2031631 \\
2034426 \\
2036994 \\
2039492 \\
2041920 \\
2044525 \\
2047302 \\
2050247 \\
2053358 \\
2056629\end{array}$ \\
\hline
\end{tabular}


Table 6. Continued

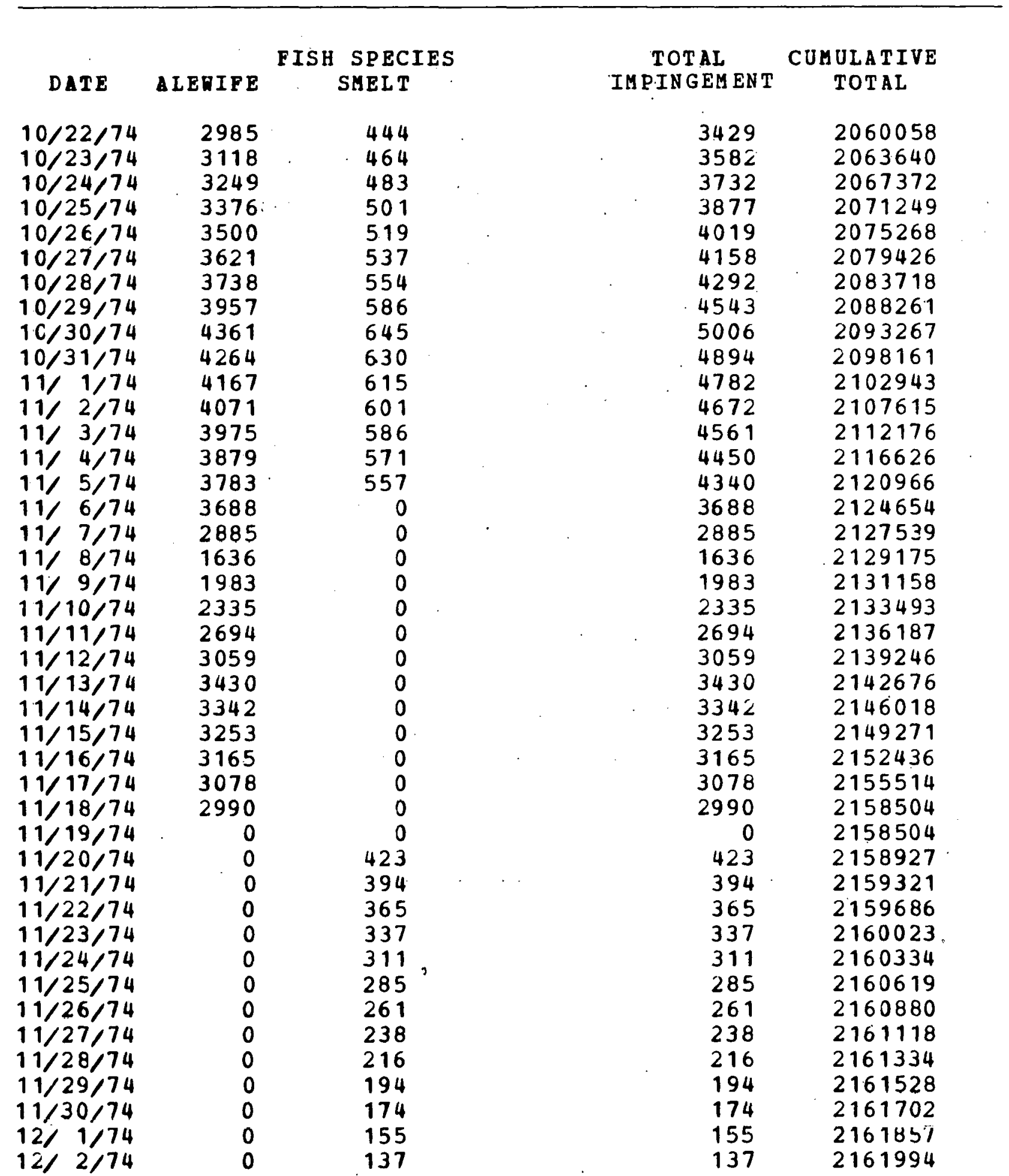


Table 6. Contịnued

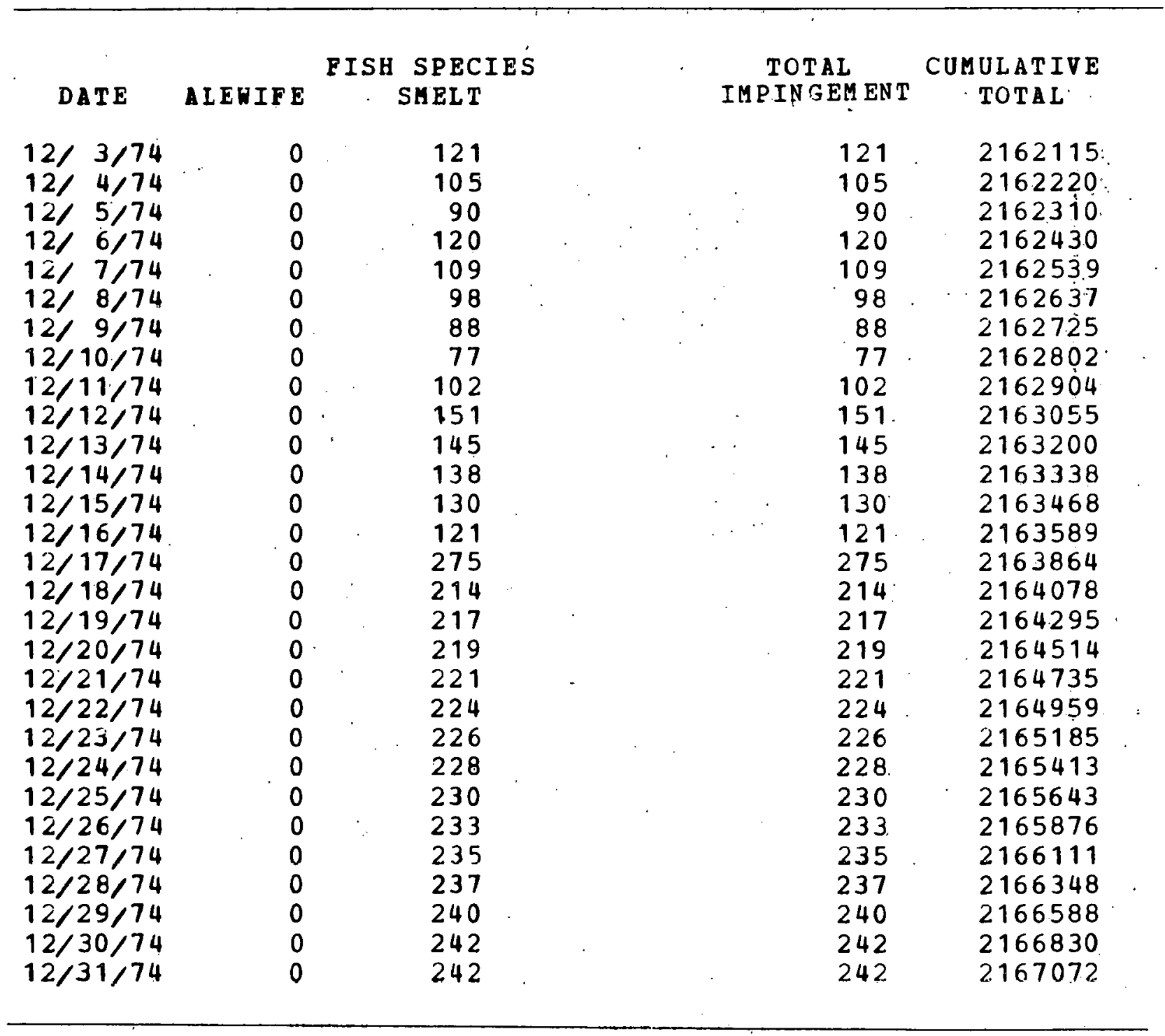




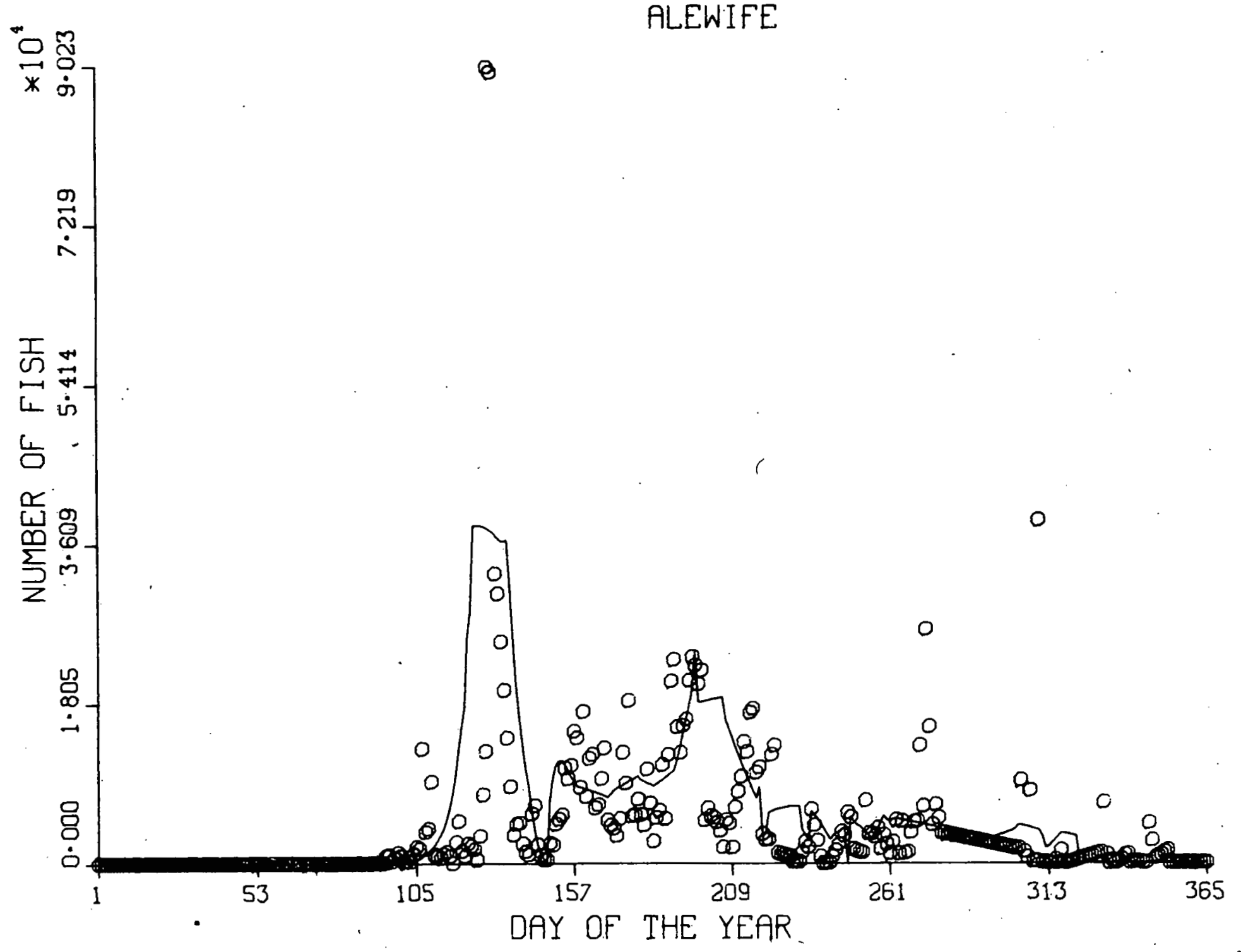

\section{PREDICTED IMPINGEMENT \\ ALEWIFE}

Fig. 10. Predicted Impingement (solid line) for Case II. and Observed Impingement (circle points) of Alewives at the Zion Station during 1974 (No. of fish/day). 


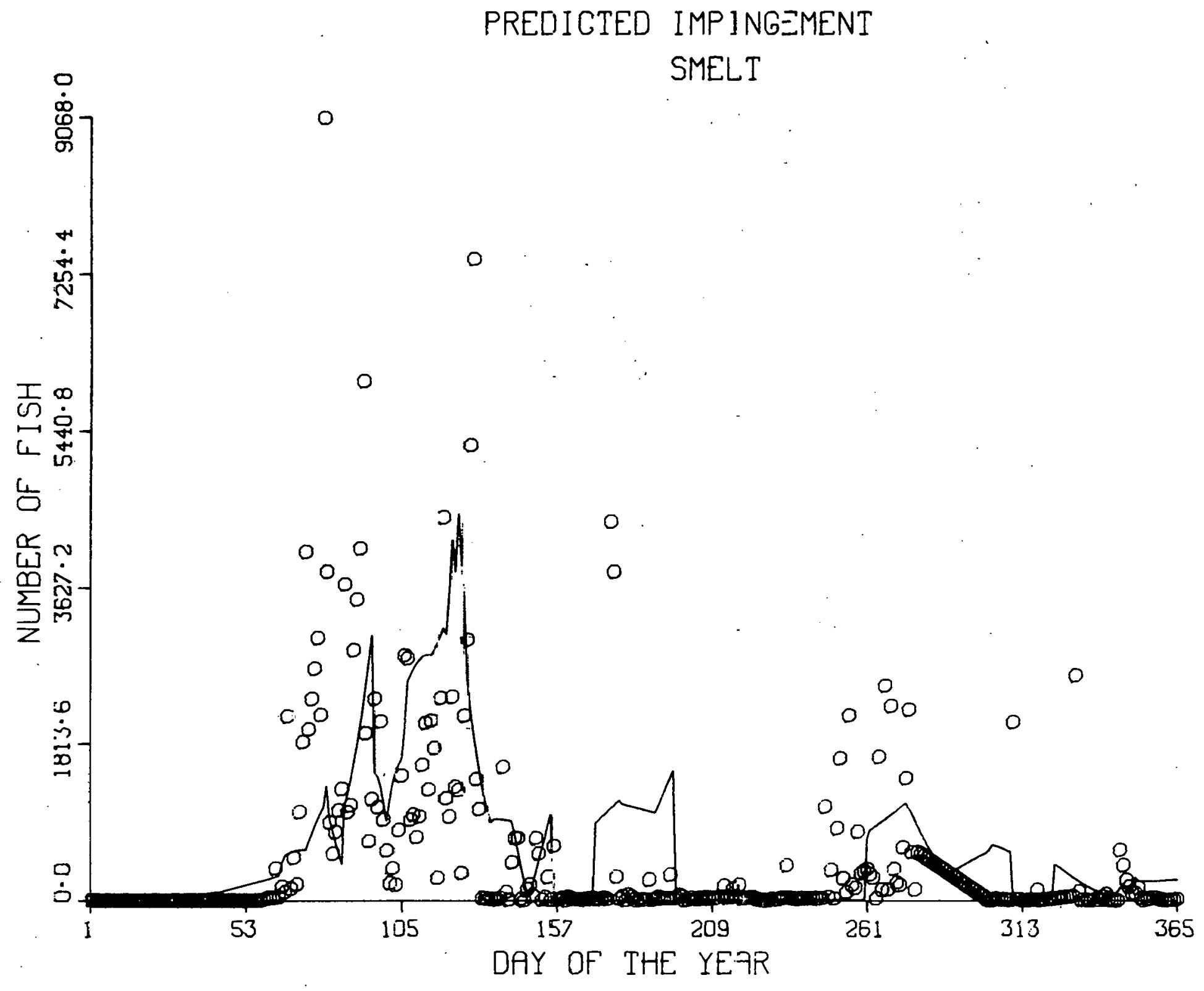

Fig. 11. Preficted Impingemert (solid line) for Case II and Observed Impingement (circles) of Smelt at the Zior. Station during 1974. (No. of fish/day). 


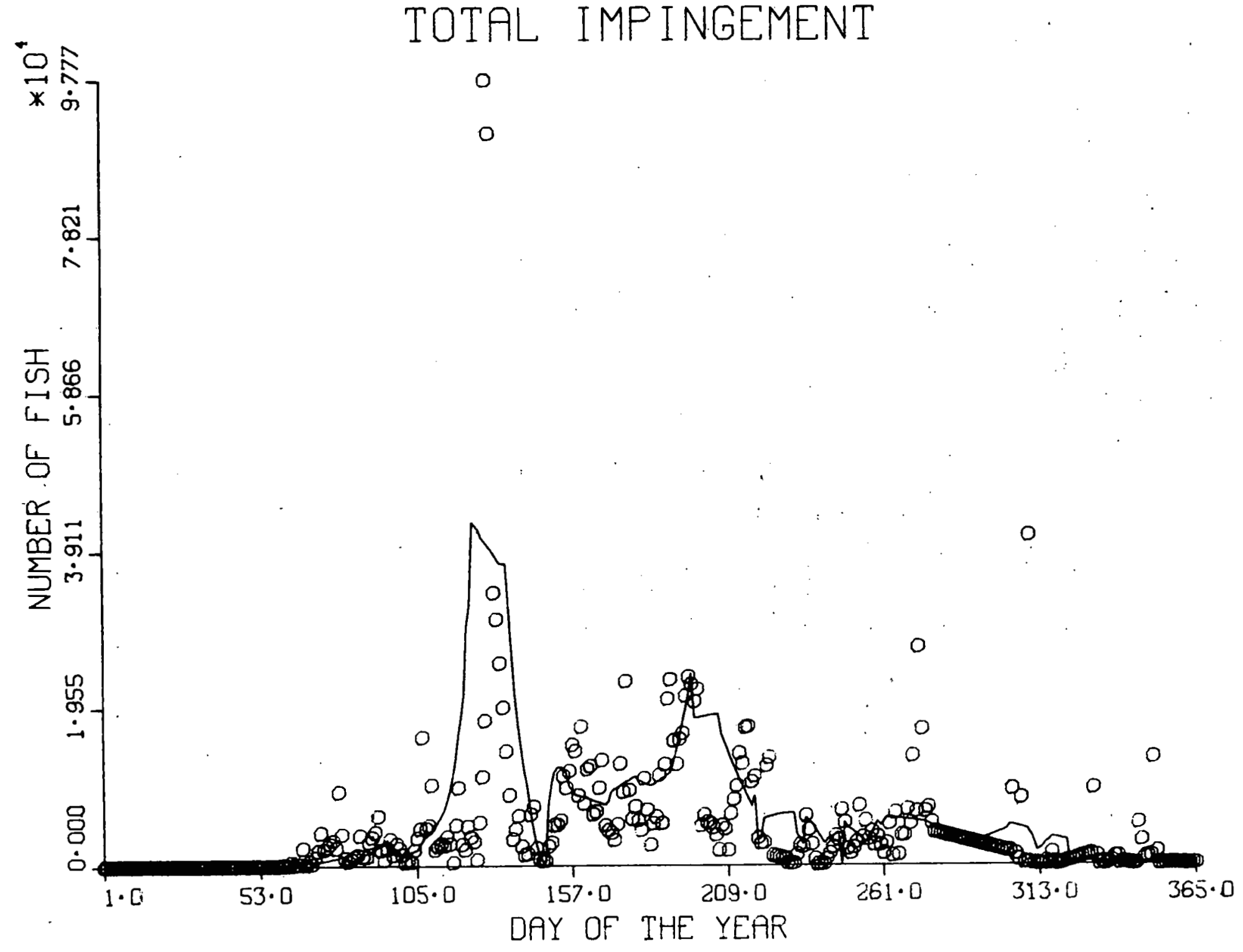

Fig. 12. Predicted Impingement (solid line) for Case II and Observed Impingement of Both Species at Zion Station during 1974 (No, of $\mathrm{fish} / \mathrm{day}$ ). 


\section{ESTIMATED PROBABILITY ALEWIFE}

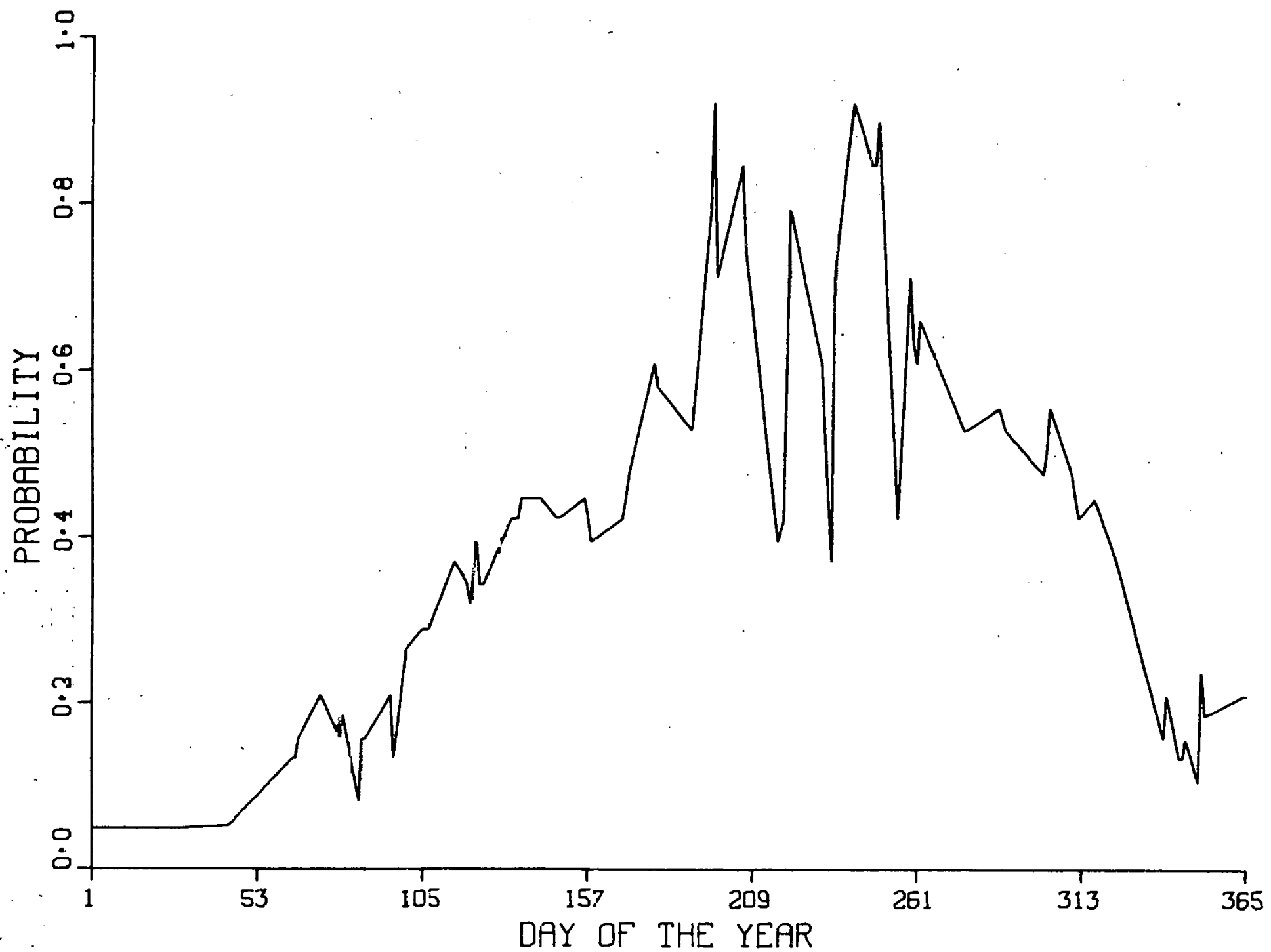

Fig. 13. The Risk of Impingerert of Alewives According to the Probability Function under the conditions of Case II. 


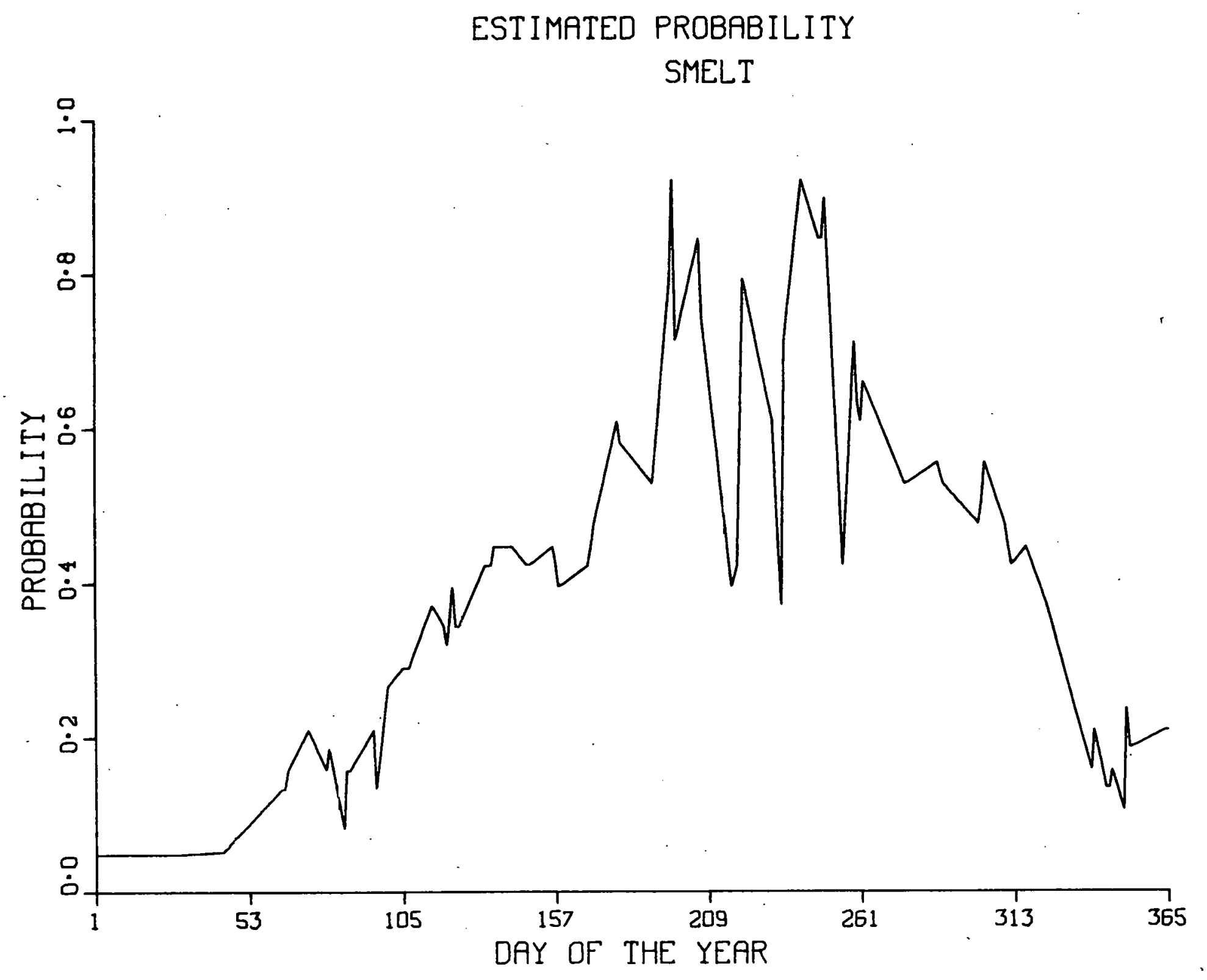

Fig. 14. The Risk of Impingement of Smelt According to the Probability Function* under the Conditions of Case II. 
Table 7. Numerical Values for Fish Density and Probability of Impingement for Case II

\begin{tabular}{|c|c|c|c|c|c|c|c|c|c|c|c|c|c|c|}
\hline & ALEWIFE & & SM & ELT & & ALEWIFE & & SM: & LT & & ALEWIFE & & $S M$ & LT \\
\hline OBS. & DENS. & PROB. & DENS. & PROB. & OBS. & DENS. & PFOB. & DENS. & PROB. & C.BS. & DENS. & PROE. & DENS. & PROB. \\
\hline 1 & 0.0 & 0.05 & 0.00 & 0.05 & 2 & 0.0 & 0.05 & 0.00 & 0.0 .5 & 3 & 0.0 & 0.05 & 0.00 & 0.05 \\
\hline 4 & 0.0 & 0.05 & 0.00 & 0.05 & 5 & 0.0 & 0.05 & 0.00 & 0.05 & 6 & 0.0 & 0.05 & 0.00 & 0.05 \\
\hline 7 & 0.0 & 0.05 & 0.00 & 0.05 & 8 & 0.0 & 0.05 & 0.00 & 0.05 & 9 & 0.0 & 0.05 & 0.00 & 0.35 \\
\hline 10 & 0.0 & 0.05 & 0.00 & 0.05 & 11 & 0.0 & 0.05 & 0.00 & 0.05 & 12 & 0.0 & 0.05 & 0.00 & 0.05 \\
\hline 13 & 0.0 & 0.05 & 0.00 & 0.05 & 14 & 0.0 & 0.05 & 0.00 & $0.0 j$ & 15 & 0.0 & 0.05 & 0.30 & 0.05 \\
\hline 16 & 0.0 & 0.05 & 0.00 & 0.05 & 17 & 0.0 & 0.05 & 0.00 & 0.05 & 18 & 0.0 & 0.05 & 0.00 & 0.05 \\
\hline 19 & 0.0 & 0.05 & 0.00 & 0.05 & 20 & 0.0 & $C .05$ & 0.00 & 0.05 & $\therefore 1$ & 0.0 & 0.05 & 0.00 & 0.05 \\
\hline 22 & 0.0 & 0.05 & 0.0 & 0.05 & 23 & 0.0 & 0.05 & $c .00$ & 0.05 & 24 & 0.0 & 0.05 & 0.00 & 0.05 \\
\hline 25 & 0.0 & 0.05 & 0.00 & 0.05 & 26 & 0.0 & 0.05 & 0.00 & 0.05 & 27 & 0.0 & 0.05 & 0.00 & 0.05 \\
\hline 28 & 0.0 & 0.05 & 0.00 & 0.05 & 25 & 0.0 & 0.05 & 0.00 & 0.05 & 30 & 0.0 & 0.05 & 0.00 & 0.05 \\
\hline 31 & 0.0 & 0.05 & 0.00 & 0.05 & 32 & 0.0 & 0.05 & 0.00 & 0.05 & 33 & 0.0 & 0.05 & 0.00 & 0.05 \\
\hline 34 & 0.0 & 0.05 & 0.00 & 0.05 & 35 & 0.0 & 0.05 & 0.00 & 0.05 & 36 & 0.0 & 0.05 & 0.00 & 0.05 \\
\hline 37 & 0.0 & 0.05 & 0.00 & 0.05 & 38 & 0.0 & 0.05 & 0.00 & 0.05 & 39 & 0.0 & 0.05 & 0.00 & 0.05 \\
\hline 40 & 0.0 & 0.05 & 0.00 & 0.05 & 41 & 0.0 & 0.05 & 0.00 & 0.05 & 42 & 0.0 & 0.05 & 0.00 & 0.05 \\
\hline 43 & 0.0 & 0.05 & 0.00 & 0.05 & 44 & 0.0 & 0.05 & 0.00 & 0.05 & 45 & 0.0 & 0.06 & 0.00 & 0.06 \\
\hline 46 & 0.0 & 0.06 & 0.00 & 0.06 & 47 & 0.0 & 0.06 & 0.00 & 0.06 & 48 & 0.0 & 0.07 & 0.01 & 0.07 \\
\hline 49 & 0.0 & 0.07 & 0.01 & 0.07 & 50 & 0.0 & 0.08 & 0.01 & 0.08 & 51 & 0.0 & 0.08 & 0.01 & 0.08 \\
\hline 52 & 0.0 & 0.08 & 0.01 & 0.08 & 53 & 0.0 & 0.09 & 0.01 & 0.09 & 54 & 0.0 & 0.09 & 0.01 & 0.09 \\
\hline 55 & 0.0 & 0.10 & 0.21 & 0.10 & 56 & 0.0 & 0.10 & 0.01 & 0.10 & 57 & 0.0 & 0.10 & 0.01 & 0.10 \\
\hline 58 & 0.0 & 0.11 & 0.01 & 0.11 & $5 S$ & 0.0 & 0.11 & 0.01 & 0.11 & 60 & 0.0 & 0.12 & 0.01 & 0.12 \\
\hline 61 & 0.0 & 0.12 & 0.01 & 0.12 & 62 & 0.0 & 0.13 & 0.01 & 0.13 & 63 & 0.0 & 0.13 & 0.01 & 0.13 \\
\hline 64 & 0.0 & 0.13 & 0.01 & 0.13 & 65 & 0.0 & 0.13 & 0.01 & 0.13 & 66 & 0.0 & 0.16 & 0.02 & 0.16 \\
\hline 67 & 0.0 & 0.16 & 0.02 & 0.16 & 68 & 0.0 & 0.17 & 0.02 & 0.17 & 69 & 0.0 & 0.18 & 0.02 & 0.18 \\
\hline 70 & 0.0 & 0.19 & 0.03 & 0.19 & 71 & 0.0 & 0.19 & 0.03 & 0.19 & 72 & 0.0 & 0.20 & 0.03 & 0.20 \\
\hline 73 & 0.0 & 0.21 & 0.04 & 0.21 & 74 & 0.0 & 0.20 & 0.04 & 0.20 & 75 & 0.0 & 0.19 & 0.04 & 0.19 \\
\hline 76 & 0.0 & 0.18 & 0.05 & 0.18 & 77 & 0.0 & 0.17 & 0.05 & 0.17 & 78 & 0.0 & 0.17 & 0.05 & 0.17 \\
\hline 79 & 0.0 & 0.16 & 0.06 & 0.16 & 80 & 0.0 & 0.19 & 0.06 & 0.19 & 81 & 0.0 & 0.16 & 0.06 & 0.16 \\
\hline 82 & 0.0 & 0.14 & 0.06 & 0.14 & 83 & 0.0 & 0.12 & 0.07 & 0.12 & 84 & 0.0 & 0.10 & 0.07 & 0.10 \\
\hline 85 & 0.0 & 0.08 & 0.07 & 0.08 & 86 & 0.0 & 0.16 & 0.08 & 0.16 & 87 & 0.00 & 0.16 & 0.09 & 0.16 \\
\hline 88 & 0.01 & 0.16 & 0.10 & 0.16 & 89 & 0.01 & 0.17 & 0.11 & 0.17 & 90 & 0.02 & 0.18 & 0.12 & 0.18 \\
\hline 91 & 0.02 & 0.18 & 0.13 & 0.10 & $\$ 2$ & 0.03 & $0.1 \mathrm{c}$ & 0.14 & 0.15 & 93 & 0.03 & 0.20 & 0.15 & 0.20 \\
\hline $\mathrm{S}_{4}$ & 0.03 & 0.20 & 0.16 & 0.20 & 95 & 0.04 & 0.21 & 0.17 & 0.21 & 9.6 & 0.04 & 0.13 & 0.18 & 0.13 \\
\hline 97 & 0.09 & 0.17 & 0.17 & 0.17 & 98 & 0.14 & 0.20 & 0.16 & 0.20 & 99 & 0.19 & 0.23 & 0.15 & 0.23 \\
\hline $1 \mathrm{CO}$ & 0.24 & 0.27 & 0.14 & 0.27 & 101 & 0.28 & 0.27 & 0.13 & 0.27 & 102 & 0.33 & 0.28 & 0.12 & 0.28 \\
\hline 103 & 0.38 & 0.28 & 0.11 & 0.28 & 104 & 0.43 & 0.29 & 0.10 & $0.2 \mathrm{c}$ & 105 & 0.48 & 0.29 & 0.08 & 0.29 \\
\hline 106 & 0.53 & 0.29 & 0.07 & 0.29 & 107 & 0.96 & $0.2 \mathrm{G}$ & 0.08 & 0.20 & 108 & 1.39 & 0.30 & 0.08 & 0.30 \\
\hline 109 & 1.82 & 0.31 & 0.09 & 0.31 & $1 \div 0$ & 2.25 & 0.32 & 0.09 & 0.32 & 111 & 2.68 & 0.33 & 0.10 & 0.33 \\
\hline 112 & 3.12 & 0.34 & 0.10 & 0.34 & $1 \div 3$ & 3.55 & 0.35 & 0.10 & 0.35 & 114 & 3.98 & 0.36 & 0.11 & 0.36 \\
\hline 115 & 4.41 & 0.37 & 0.11 & 0.37 & $1: 6$ & 4.84 & 0.36 & 0.12 & $0.3 E$ & 117 & 5.27 & 0.36 & 0.12 & 0.36 \\
\hline 118 & 5.70 & 0.35 & 0.13 & 0.35 & 119 & 6.14 & 0.34 & 0.13 & 0.34 & 120 & 6.57 & 0.32 & 0.13 & 0.32 \\
\hline 121 & 7.00 & 0.36 & 0.14 & 0.36 & 122 & 7.43 & 0.40 & 0.14 & 0.40 & $12 \mathrm{~s}$ & 7.86 & 0.34 & 0.15 & 0.34 \\
\hline 124 & 7.87 & 0.34 & 0.14 & 0.34 & 125 & 7.87 & 0.35 & 0.12 & 0.35 & 126 & 7.88 & 0.36 & 0.11 & 0.36 \\
\hline 127 & 7.88 & 0.37 & 0.10 & 0.37 & 128 & 7.88 & 0.38 & 0.09 & 0.38 & 129 & 7.89 & 0.39 & 0.08 & 0.39 \\
\hline 130 & 7.89 & 0.40 & 0.07 & 0.40 & 131 & 7.90 & 0.41 & 0.06 & 0.41 & 132 & 7.90 & 0.41 & 0.04 & 0.41 \\
\hline 133 & 7.91 & 0.42 & 0.03 & 0.42 & 134 & 7.91 & $0 .+2$ & 0.02 & 0.42 & $1=5$ & 7.92 & 0.42 & 0.01 & 0.42 \\
\hline 136 & 7.56 & 0.45 & 0.01 & 0.45 & 137 & 7.21 & 0.45 & 0.01 & 0.45 & 138 & 6.95 & 0.45 & 0.01 & 0.45 \\
\hline
\end{tabular}


Table 7. Continued

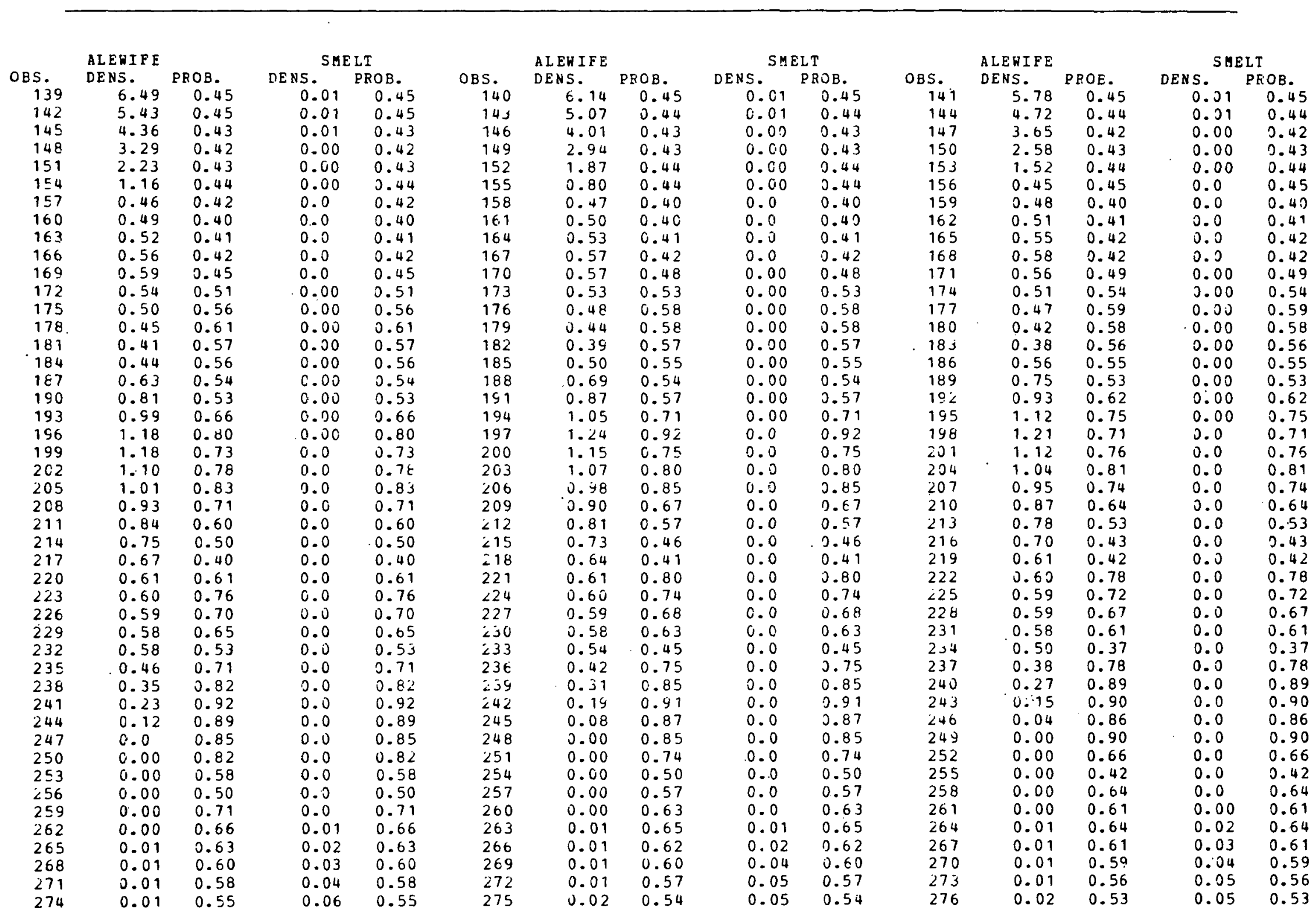


Table 7. Continued

ALERIFE

OBS.

$\begin{array}{llr} & \text { DENS. } & \text { PROB. } \\ 277 & 0.03 & 0.53 \\ 280 & 0.05 & 0.54 \\ 283 & 0.07 & 0.55 \\ 286 & 0.08 & 0.55 \\ 289 & 0.09 & 0.53 \\ 292 & 0.08 & 0.52 \\ 295 & 0.07 & 0.50 \\ 298 & 0.06 & 0.49 \\ 301 & 0.06 & 0.48 \\ 304 & 0.05 & 0.55 \\ 307 & 0.04 & 0.51 \\ 310 & 0.03 & 0.48 \\ 313 & 0.03 & 0.43 \\ 316 & 0.02 & 0.44 \\ 319 & 0.01 & 0.43 \\ 322 & 0.00 & 0.39 \\ 325 & 0.0 & 0.36 \\ 328 & 0.0 & 0.31 \\ 331 & 0.0 & 0.27 \\ 334 & 0.0 & 0.23 \\ 337 & 0.0 & 0.19 \\ 340 & 0.0 & 0.21 \\ 343 & 0.0 & 0.15 \\ 346 & 0.0 & 0.16 \\ 349 & 0.0 & 0.12 \\ 352 & 0.0 & 0.19 \\ 355 & 0.0 & 0.19 \\ 358 & 0.0 & 0.20 \\ 361 & 0.0 & 0.20 \\ 364 & 0.0 & 0.21\end{array}$

SMELT.

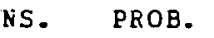

$0.04 \quad 0.53$

$\begin{array}{ll}0.04 & 0.54 \\ 0.03 & 0.55\end{array}$

$0.02 \quad 0.55$

$0.00 \quad 0.53$

$\begin{array}{ll}0.00 & 0.53 \\ 0.00 & 0.52\end{array}$

$\begin{array}{ll}0.00 & 0.52 \\ 0.00 & 0.50\end{array}$

$0.00 \quad 0.49$

$0.00 \quad 0.48$

$0.00 \quad 0.55$

$0.00 \quad 0.51$

$0.0 \quad 0.48$

$0.0 \quad 0.43$

$0.0 \cdot 0.44$

$\begin{array}{ll}0.0 & 0.43 \\ 0.0 & 0.39\end{array}$

$0.00 \quad 0.36$

$0.00 \quad 0.31$

$0.00 \quad 0.27$

$0.00 \quad 0.23$

$0.00 \quad 0.19$

$\begin{array}{ll}0.00 & 0.21 \\ 0.00 & 0.15\end{array}$

$\begin{array}{ll}0.00 & 0.15 \\ 0.00 & 0.16\end{array}$

$0.00 \quad 0.12$

$0.00 \quad 0.19$

$0.00 \quad 0.19$

$0.00 \quad 0.20$

$0.00 \quad 0.20$

\section{. ALEWIFE}

278

278
281

284

287

290

293

296
299

299
302

302

305

308

311

314

317
320

320
$32 j$

326

329

332

335

338

341

344
347

350

353

356

359

352
ENS.

0.04 PROB.

$0.04 \quad 0.53$

$0.05 \quad 0.54$

$\begin{array}{ll}0.07 & 0.55 \\ 0.09 & 0.56\end{array}$

$0.08 \quad 0.52$

$0.08 \quad 0.51$

$0.07 \quad 0.50$

$\begin{array}{ll}0.06 & 0.48 \\ 0.05 & 0.50\end{array}$

$\begin{array}{ll}0.05 & 0.50 \\ 0.05 & 0.53\end{array}$

$0.05 \quad 0.53$

$\begin{array}{ll}0.03 & 0.45\end{array}$

$0.02 \quad 0.43$

$0.02 \quad 0.45$

$0.01 \quad 0.41$

$0.0 \quad 0.38$

$\begin{array}{ll}0.0 & 0.34 \\ 0.0 & 0.34\end{array}$

$0.0 \quad 0.26$

$0.0 \quad 0.21$

$0.0 \quad 0.17$

$0.0 \quad 0.19$

$0.0 \quad 0.13$

$0.0 \cdot 0.14$

$0.0 \quad 0.10$

$0.0 \quad 0.19$

$0.0 \quad 0.20$

$0.0 \quad 0.21$
SMELT

$0.04 \quad 0.53$ OBS.

$0.03 \quad 0.54$

$0.02 \quad 0.55$

$\begin{array}{ll}0.00 & 0.55 \\ 0.00 & 0.52\end{array}$

$0.00 \quad 0.51$

$0.00 \quad 0.51$

$0.00 \quad 0.48$
$0.00 \quad 2.50$

$0.00 \quad 2.50$

$0.00 \quad 0.53$

$\begin{array}{ll}0.00 & 0.51 \\ 0.0 & 0.45\end{array}$

$\begin{array}{ll}0.0 & 0.45 \\ 0.0 & 0.43\end{array}$

$0.0 \quad 0.45$

$\begin{array}{ll}0.0 & 0.41 \\ 0.0 & 0.38\end{array}$

$\begin{array}{ll}0.0 & 0.38 \\ 0.00 & 0.34\end{array}$

$0.00 \quad 0.30$

$0.00 \quad 0.26$

$0.00 \quad 0.21$

$0.00 \quad 0.17$

$0.00 \quad 0.19$

$\begin{array}{ll}0.00 & 0.13 \\ 0.00 & 0.14\end{array}$

$0.00 \quad 0.10$

$0.00 \quad 0.19$

$0.00 \quad 0.19$

$0.00 \quad 0.20$

$0.00 \quad 0.21$
A LEWIFE

279

282

285

288

291

294
297

297
300

303

306

309

372

315

318
321

324
327

327
330

$3=3$

336

339

342

345

348
351

354

357

360

363

DENS.
0.04 PROB.

$0.04 \quad 0.54$

$0.08 \quad 0.54$

0.090 .54

$0.08 \quad 0.52$

$0.07 \quad 0.51$

$0.07 \quad 0.49$

$\begin{array}{ll}0.06 & 0.48 \\ 0.05 & 0.56\end{array}$

$0.04 \quad 0.52$

$0.04 \quad 0.49$

$0.03 \quad 0.42$

0.020 .44

0.010 .44

$0.01 \quad 0.40$

$0.0 \quad 0.37$

$0.0 \quad 0.33$

$0.0 \quad 0.29$

$0.0 \quad 0.24$

$\begin{array}{ll}0.0 & 0.20 \\ 0.0 & 0.16\end{array}$

0.16

0.13

0.13
0.13

0.24

0.19

0.20

0.20

0.21
0.04 PROB.

$0.02 \quad 0.54$

$0.01 \quad 0.55$

$0.00 \quad 0.54$

$0.00 \quad 0.52$

$0.00 \quad 0.51$

$0.00 \quad 0.49$

$0.00 \quad 0.48$

$0.00 \quad 0.56$

$0.00 \quad 0.52$

$0.00 \quad 0.49$

$0.0 \quad 0.44$

$0.0 \quad 0.44$

$0.0 \quad 0.40$

$\begin{array}{ll}0.00 & 0.33\end{array}$

$0.00 \quad 0.29$

$0.00 \quad 0.24$

$0.00 \quad 0.20$

$0.00 \quad 0.16$

$0.00 \quad 0.17$

$0.00 \quad 0.13$

$0.00 \quad 0.24$

$0.00 \quad 0.19$

$0.00 \quad 0.20$

$0.00 \quad 0.20$

$0.00 \quad 0.21$ 
Table 8. Daily Fish-Impingement Predictions Calculated According to Case-III Specifications

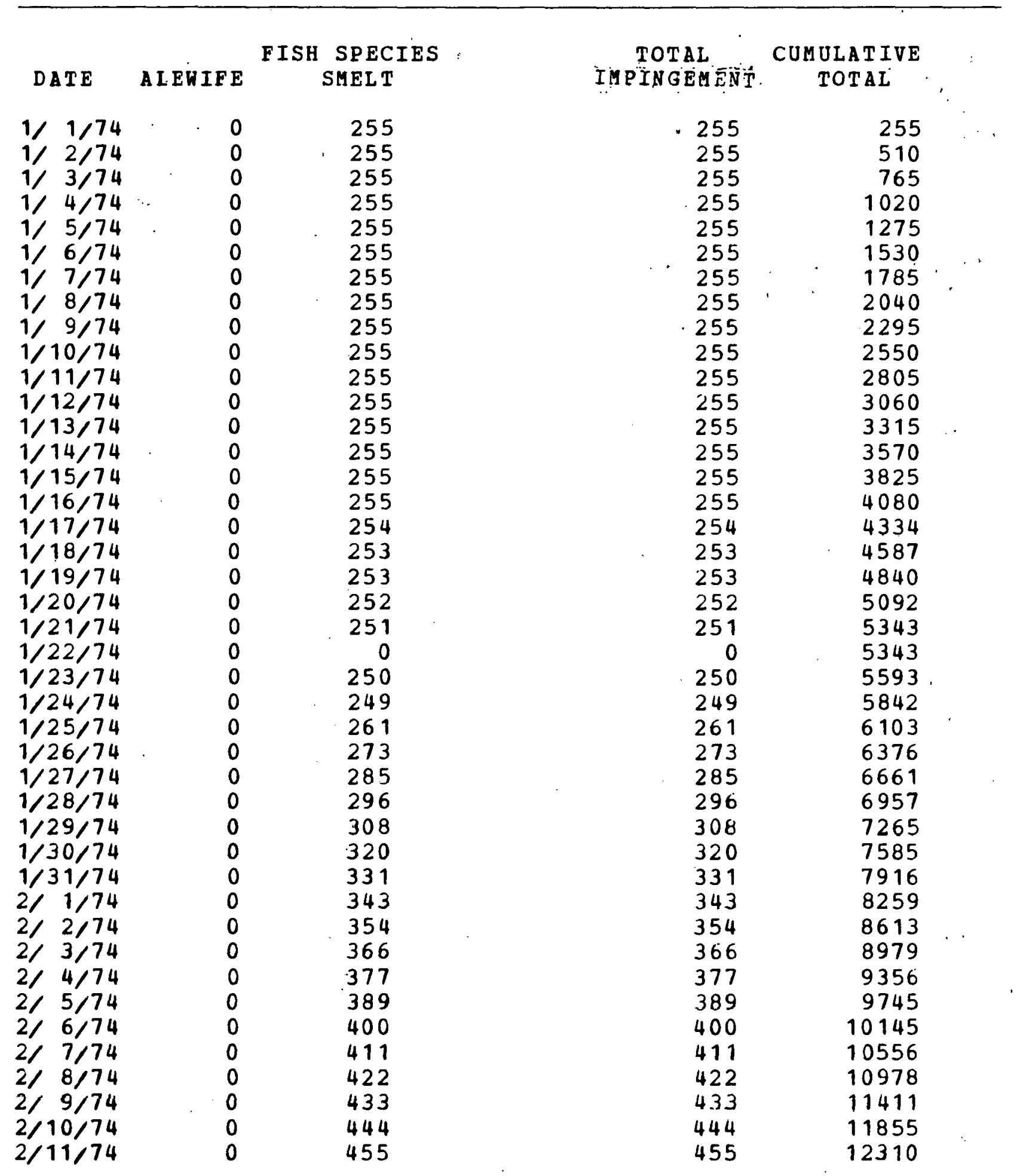


Table 8. Continued

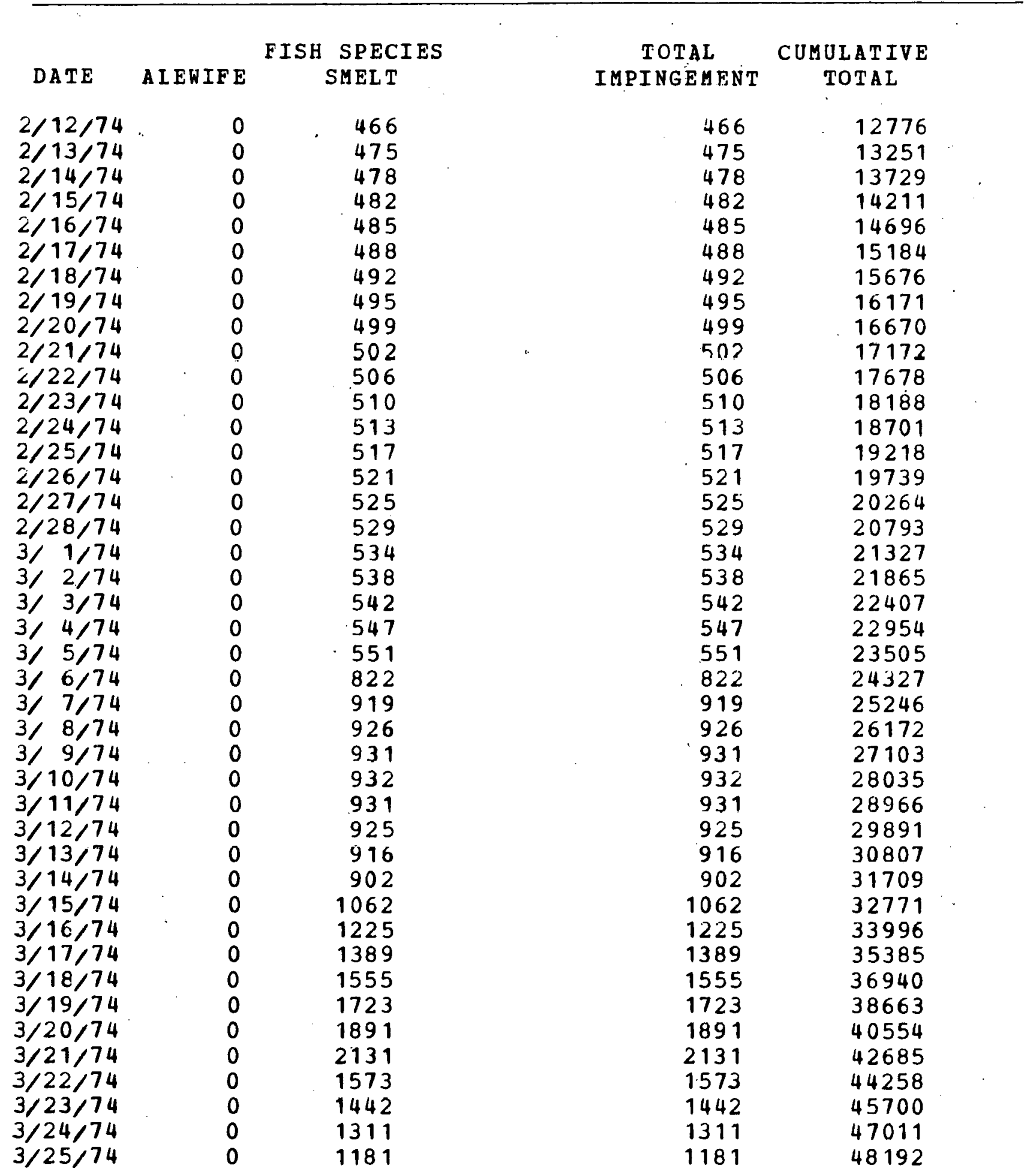


Table 8. Continued

\begin{tabular}{|c|c|c|c|c|c|}
\hline DATE & ALEWIFE & $\begin{array}{c}\text { FISH } \\
\text { SMELT }\end{array}$ & & $\begin{array}{c}\text { TOTAL } \\
\text { IMPINGEMEHT }\end{array}$ & $\begin{array}{c}\text { CUMULATIVE } \\
\text { TOTAL }\end{array}$ \\
\hline $\begin{array}{l}3 / 26 / 74 \\
3 / 27 / 74 \\
3 / 28 / 74 \\
3 / 29 / 74 \\
3 / 30 / 74 \\
3 / 31 / 74 \\
4 / 1 / 74 \\
4 / 2 / 74 \\
4 / 3 / 74 \\
4 / 4 / 74 \\
4 / 5 / 74 \\
4 / 6 / 74 \\
4 / 7 / 74 \\
4 / 8 / 74 \\
4 / 9 / 74 \\
4 / 10 / 74 \\
4 / 11 / 74 \\
4 / 12 / 74 \\
4 / 13 / 74 \\
4 / 14 / 74 \\
4 / 15 / 74 \\
4 / 16 / 74 \\
4 / 17 / 74 \\
4 / 18 / 74 \\
4 / 19 / 74 \\
4 / 20 / 74 \\
4 / 21 / 74 \\
4 / 22 / 74 \\
4 / 23 / 74 \\
4 / 24 / 74 \\
4 / 25 / 74 \\
4 / 26 / 74 \\
4 / 27 / 74 \\
4 / 28 / 74 \\
4 / 29 / 74 \\
4 / 30 / 74 \\
5 / 1 / 74 \\
5 / 2 / 74 \\
5 / 3 / 74 \\
5 / 4 / 74 \\
5 / 5 / 74 \\
5 / 6 / 74\end{array}$ & $\begin{array}{r}0 \\
0 \\
320 \\
318 \\
316 \\
312 \\
309 \\
305 \\
300 \\
295 \\
290 \\
150 \\
152 \\
149 \\
141 \\
127 \\
185 \\
248 \\
316 \\
389 \\
467 \\
641 \\
1045 \\
1324 \\
1671 \\
2101 \\
2629 \\
3275 \\
4059 \\
5000 \\
6118 \\
7851 \\
10076 \\
12931 \\
16596 \\
20626 \\
23067 \\
32053 \\
38025 \\
50842 \\
50383 \\
49875\end{array}$ & $\begin{array}{l}1053 \\
1911 \\
2134 \\
2357 \\
2600 \\
2864 \\
3151 \\
3462 \\
3797 \\
4158 \\
4545 \\
2650 \\
2309 \\
1948 \\
1582 \\
1224 \\
1539 \\
1777 \\
1950 \\
2069 \\
2144 \\
2537 \\
3323 \\
3384 \\
3436 \\
3475 \\
3502 \\
3513 \\
3507 \\
3482 \\
3435 \\
3548 \\
3664 \\
3783 \\
3905 \\
3888 \\
4412 \\
4978 \\
4703 \\
5542 \\
4852 \\
4243\end{array}$ & . & $\begin{array}{r}1053 \\
1911 \\
2454 \\
2675 \\
2916 \\
3176 \\
3460 \\
3767 \\
4097 \\
4453 \\
4835 \\
2800 \\
2461 \\
2097 \\
1723 \\
1351 \\
1724 \\
2025 \\
2266 \\
2458 \\
2611 \\
3178 \\
4368 \\
4708 \\
5107 \\
5576 \\
6131 \\
6788 \\
7566 \\
8482 \\
9553 \\
11399 \\
13740 \\
16714 \\
20501 \\
24514 \\
27479 \\
37031 \\
42728 \\
56384 \\
55235 \\
54118\end{array}$ & $\begin{array}{r}49245 \\
51156 \\
53610 \\
56285 \\
59201 \\
62377 \\
65837 \\
69604 \\
73701 \\
78154 \\
82989 \\
85789 \\
88250 \\
90347 \\
92070 \\
93421 \\
95145 \\
97170 \\
99436 \\
101894 \\
104505 \\
107683 \\
112051 \\
116759 \\
121866 \\
127442 \\
133573 \\
140361 \\
147927 \\
156409 \\
165962 \\
177361 \\
191101 \\
207815 \\
228316 \\
252830 \\
280309 \\
317340 \\
360068 \\
416452 \\
471687 \\
525805\end{array}$ \\
\hline
\end{tabular}


Table 8. Continued

\begin{tabular}{|c|c|c|}
\hline DATE & AIEHIFE & $\begin{array}{r}\text { FISH SPEC } \\
\text { SHELT }\end{array}$ \\
\hline $\begin{array}{l}5 / 7 / 74 \\
5 / 8 / 74 \\
5 / 9 / 74 \\
5 / 10 / 74 \\
5 / 11 / 74 \\
5 / 12 / 74 \\
5 / 13 / 74 \\
5 / 14 / 74 \\
5 / 15 / 74 \\
5 / 16 / 74 \\
5 / 17 / 74 \\
5 / 18 / 74 \\
5 / 19 / 74 \\
5 / 20 / 74 \\
5 / 21 / 74 \\
5 / 22 / 74 \\
5 / 23 / 74 \\
5 / 24 / 74 \\
5 / 25 / 74 \\
5 / 26 / 74 \\
5 / 27 / 74 \\
5 / 28 / 74 \\
5 / 29 / 74 \\
5 / 30 / 74 \\
5 / 31 / 74 \\
6 / 1 / 74 \\
6 / 2 / 74 \\
6 / 3 / 74 \\
6 / 4 / 74 \\
6 / 5 / 74 \\
6 / 6 / 74 \\
6 / 7 / 74 \\
6 / 8 / 74 \\
6 / 9 / 74 \\
6 / 10 / 74 \\
6 / 11 / 74 \\
6 / 12 / 74 \\
6 / 13 / 74 \\
6 / 14 / 74 \\
6 / 15 / 74 \\
6 / 16 / 74 \\
6 / 17 / 74\end{array}$ & $\begin{array}{r}49316 \\
48707 \\
48048 \\
47336 \\
46574 \\
45759 \\
44891 \\
45017 \\
45144 \\
37772 \\
30449 \\
24546 \\
19788 \\
15951 \\
12859 \\
10365 \\
676\end{array}$ & 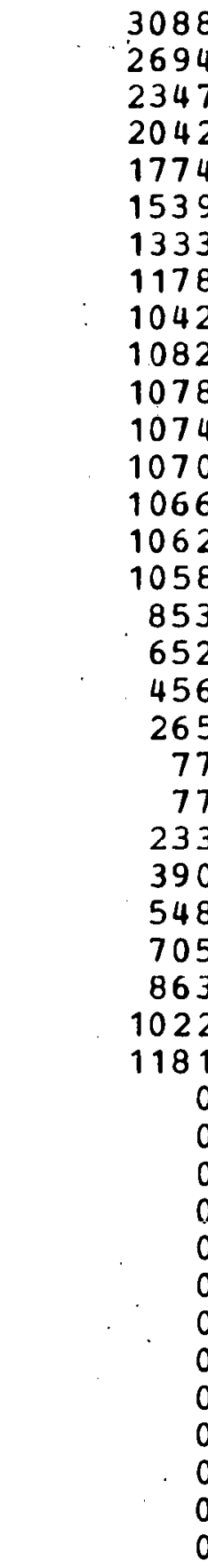 \\
\hline
\end{tabular}

\section{TOTAL CUMULATIVE IMPINGEMENT TOTAL}

\begin{tabular}{rr}
52404 & 578209 \\
51401 & 629610 \\
50395 & 680005 \\
49378 & 729383 \\
48348 & 777731 \\
47298 & 825029 \\
46224 & 871253 \\
46195 & 917448 \\
46186 & 963634 \\
38854 & 1002488 \\
31527 & 1034015 \\
25620 & 1059635 \\
20858 & 1080493 \\
17017 & 1097510 \\
13921 & 1111431 \\
11423 & 1122854 \\
7615 & 1130469 \\
4837 & 1135306 \\
2824 & 1138130 \\
1376 & 1139506 \\
340 & 1139846 \\
289 & 1140135 \\
8663 & 1148798 \\
11791 & 1160589 \\
13488 & 1174077 \\
14188 & 1188265 \\
14217 & 1202482 \\
13810 & 1216292 \\
13137 & 1229429 \\
10979 & 1240408 \\
10593 & 1251001 \\
10110 & 1261111 \\
9976 & 1271087 \\
9836 & 1280923 \\
9692 & 1290615 \\
9542 & 1300157 \\
9387 & 1309544 \\
9227 & 1318771 \\
9062 & 1327833 \\
8891 & 1336724 \\
8714 & 1345438 \\
8532 & 1353970 \\
& \\
\hline 135 &
\end{tabular}


Table 8. Continued

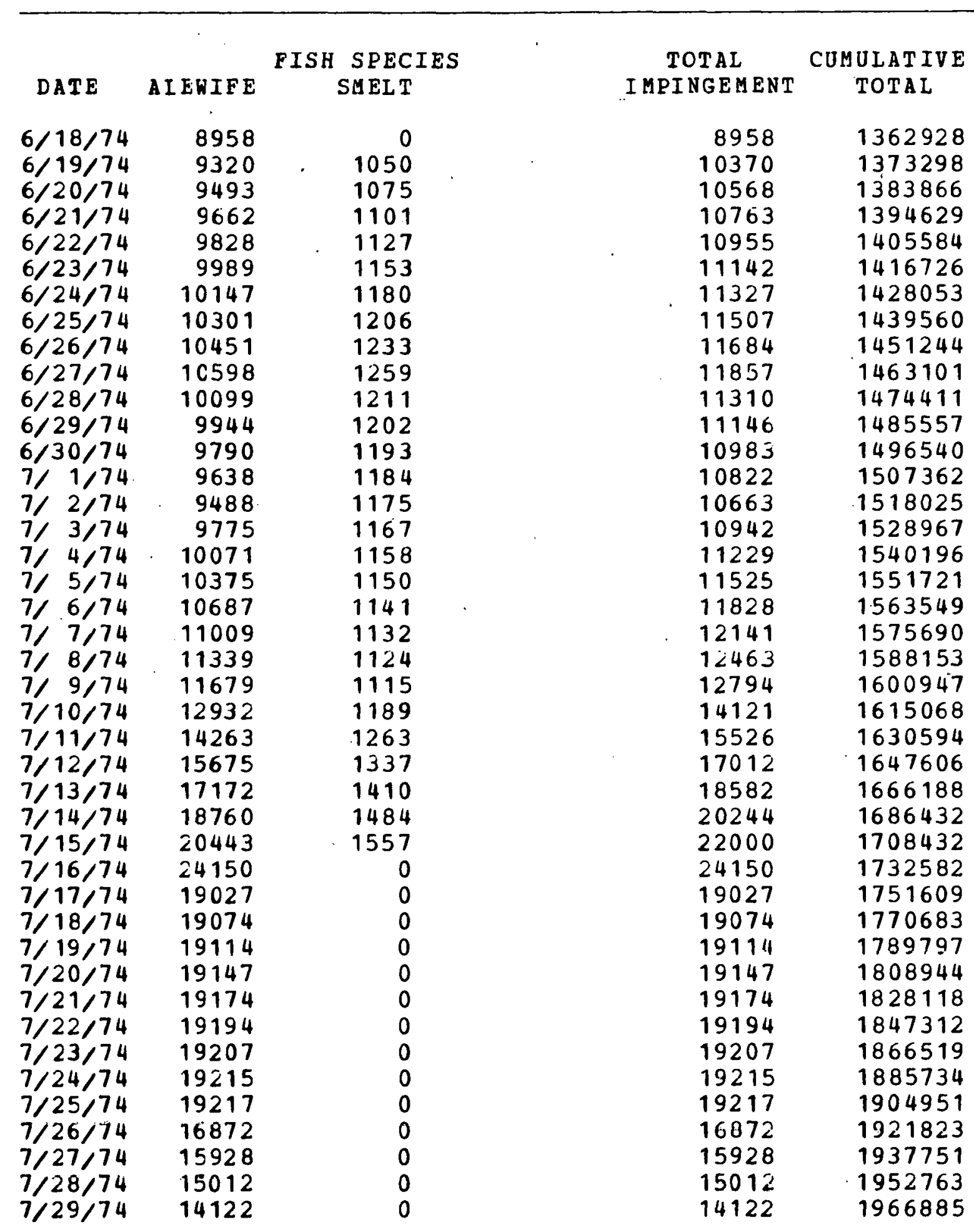


Table 8. Continued

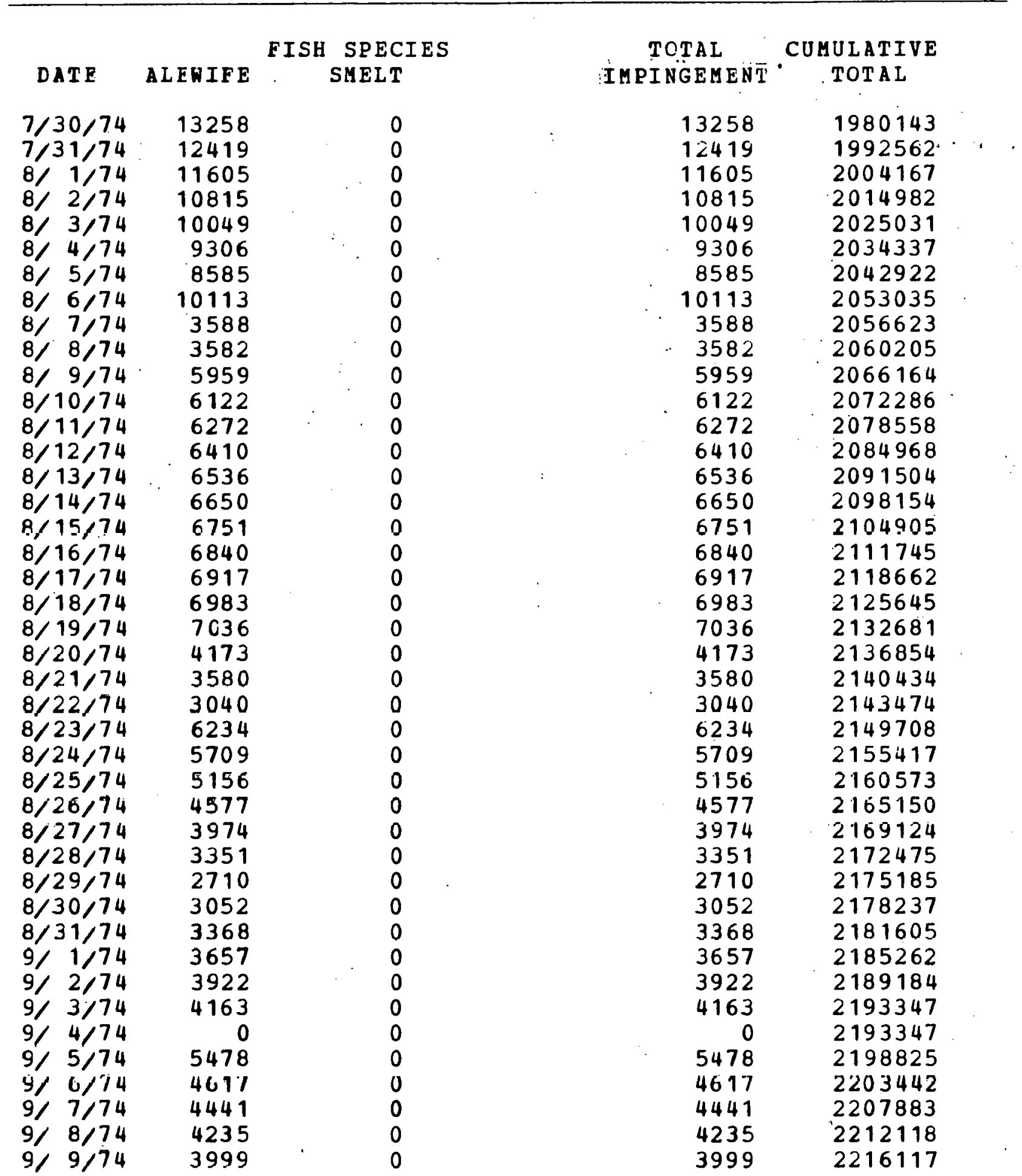


Table 8. Continued

\begin{tabular}{|c|c|c|c|c|}
\hline DATE & A I EWIFE & $\begin{array}{c}\text { FISH SPECIES } \\
\text { SHELT }\end{array}$ & $\begin{array}{c}\text { TOTAL } \\
\text { I MPINGEMENT }\end{array}$ & $\begin{array}{l}\text { CUMULATIVE } \\
\text { TOTAL }\end{array}$ \\
\hline $\begin{array}{l}9 / 10 / 74 \\
9 / 11 / 74 \\
9 / 12 / 74 \\
9 / 13 / 74 \\
9 / 14 / 74 \\
9 / 15 / 74 \\
9 / 16 / 74 \\
9 / 17 / 74 \\
9 / 18 / 74 \\
9 / 19 / 74 \\
9 / 20 / 74 \\
9 / 21 / 74 \\
9 / 22 / 74 \\
9 / 23 / 74 \\
9 / 24 / 74 \\
9 / 25 / 74 \\
9 / 26 / 74 \\
9 / 27 / 74 \\
9 / 28 / 74 \\
9 / 29 / 74 \\
9 / 30 / 74 \\
10 / 1 / 74 \\
10 / 2 / 74 \\
10 / 3 / 74 \\
10 / 4 / 74 \\
10 / 5 / 74 \\
10 / 6 / 74 \\
10 / 7 / 74 \\
10 / 8 / 74 \\
10 / 9 / 74 \\
10 / 10 / 74 \\
10 / 11 / 74 \\
10 / 12 / 74 \\
10 / 13 / 74 \\
10 / 14 / 74 \\
10 / 15 / 74 \\
10 / 16 / 74 \\
10 / 17 / 74 \\
10 / 18 / 74 \\
10 / 19 / 74 \\
10 / 20 / 74 \\
10 / 21 / 74\end{array}$ & $\begin{array}{l}3734 \\
3439 \\
3114 \\
3697 \\
4320 \\
4984 \\
5689 \\
5146 \\
4990 \\
5345 \\
5284 \\
5224 \\
5164 \\
5103 \\
5043 \\
4983 \\
4922 \\
4862 \\
4802 \\
4742 \\
4682 \\
4622 \\
4574 \\
4527 \\
4353 \\
4177 \\
3998 \\
3816 \\
3630 \\
3442 \\
3251 \\
3057 \\
2859 \\
2659 \\
2455 \\
2402 \\
2349 \\
2524 \\
2697 \\
2867 \\
3034 \\
3197\end{array}$ & $\begin{array}{r}0 \\
0 \\
0 \\
0 \\
0 \\
0 \\
0 \\
0 \\
800 \\
888 \\
916 \\
944 \\
972 \\
1002 \\
1032 \\
1062 \\
1094 \\
1125 \\
1158 \\
1191 \\
1225 \\
1259 \\
1192 \\
1127 \\
1036 \\
950 \\
869 \\
793 \\
721 \\
653 \\
589 \\
530 \\
473 \\
421 \\
371 \\
363 \\
354 \\
381 \\
406 \\
431 \\
456 \\
480\end{array}$ & $\begin{array}{l}3734 \\
3439 \\
3114 \\
3697 \\
4320 \\
4984 \\
5689 \\
5146 \\
5790 \\
6233 \\
6200 \\
6168 \\
6136 \\
6105 \\
6075 \\
6045 \\
6016 \\
5987 \\
5960 \\
5933 \\
5907 \\
5881 \\
5766 \\
5654 \\
5389 \\
5127 \\
4867 \\
4609 \\
4351 \\
4095 \\
3840 \\
3587 \\
3332 \\
3080 \\
2826 \\
2765 \\
2703 \\
2905 \\
3103 \\
3298 \\
3490 \\
3677\end{array}$ & $\begin{array}{l}2219851 \\
2223290 \\
2226404 \\
2230101 \\
2234421 \\
2239405 \\
2245094 \\
2250240 \\
2256030 \\
2262263 \\
2268463 \\
2274631 \\
2280767 \\
2286872 \\
2292947 \\
2298992 \\
2305008 \\
2310995 \\
2316955 \\
2322888 \\
2328795 \\
2334676 \\
2340442 \\
2346096 \\
2351485 \\
2356612 \\
2361479 \\
2366088 \\
2370439 \\
2374534 \\
2378374 \\
2381961 \\
2385293 \\
2388373 \\
2391199 \\
2393964 \\
2396667 \\
2399572 \\
2402675 \\
2405973 \\
2409463 \\
2413140\end{array}$ \\
\hline
\end{tabular}


Table 8. Continued

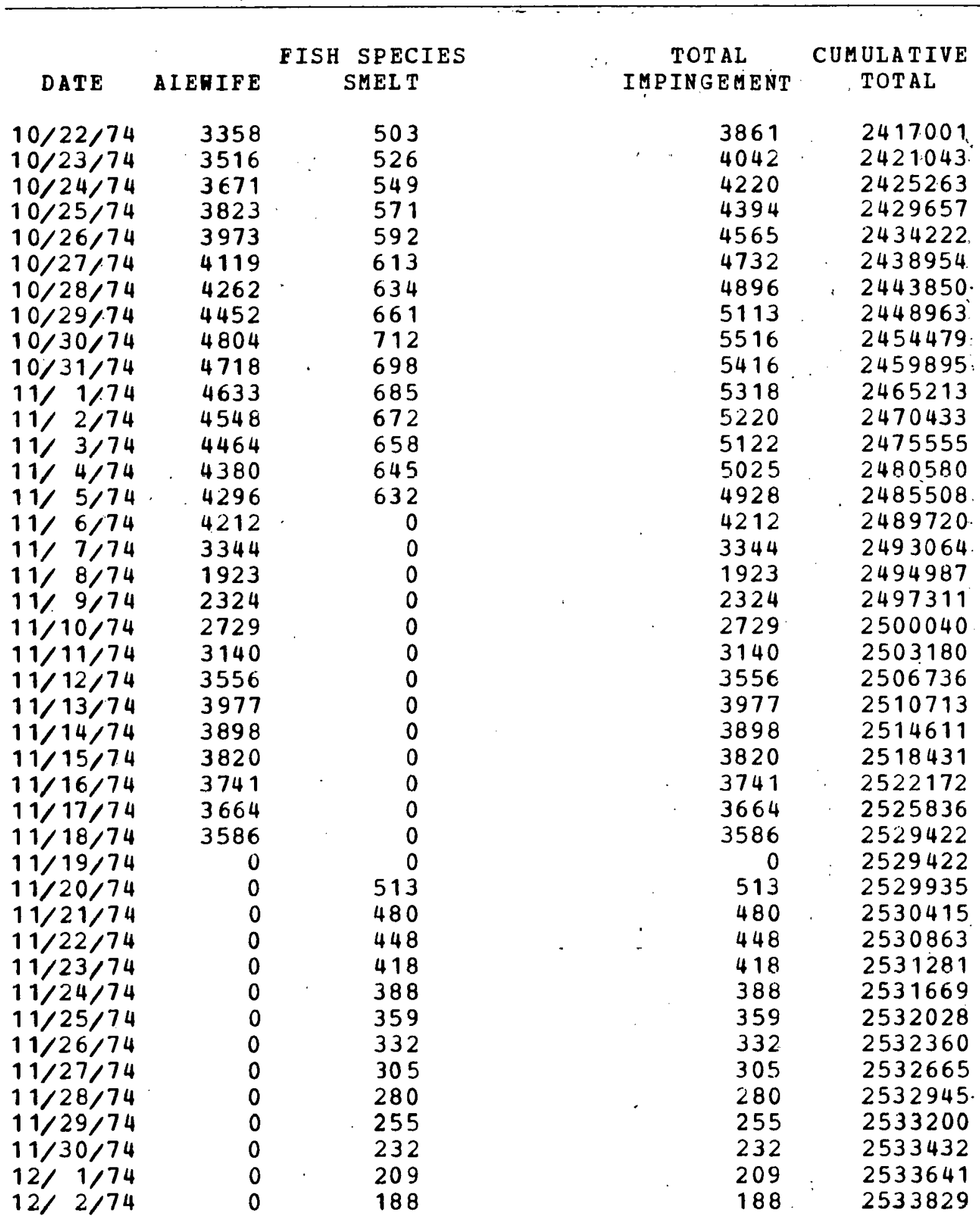


Table 8. Continued

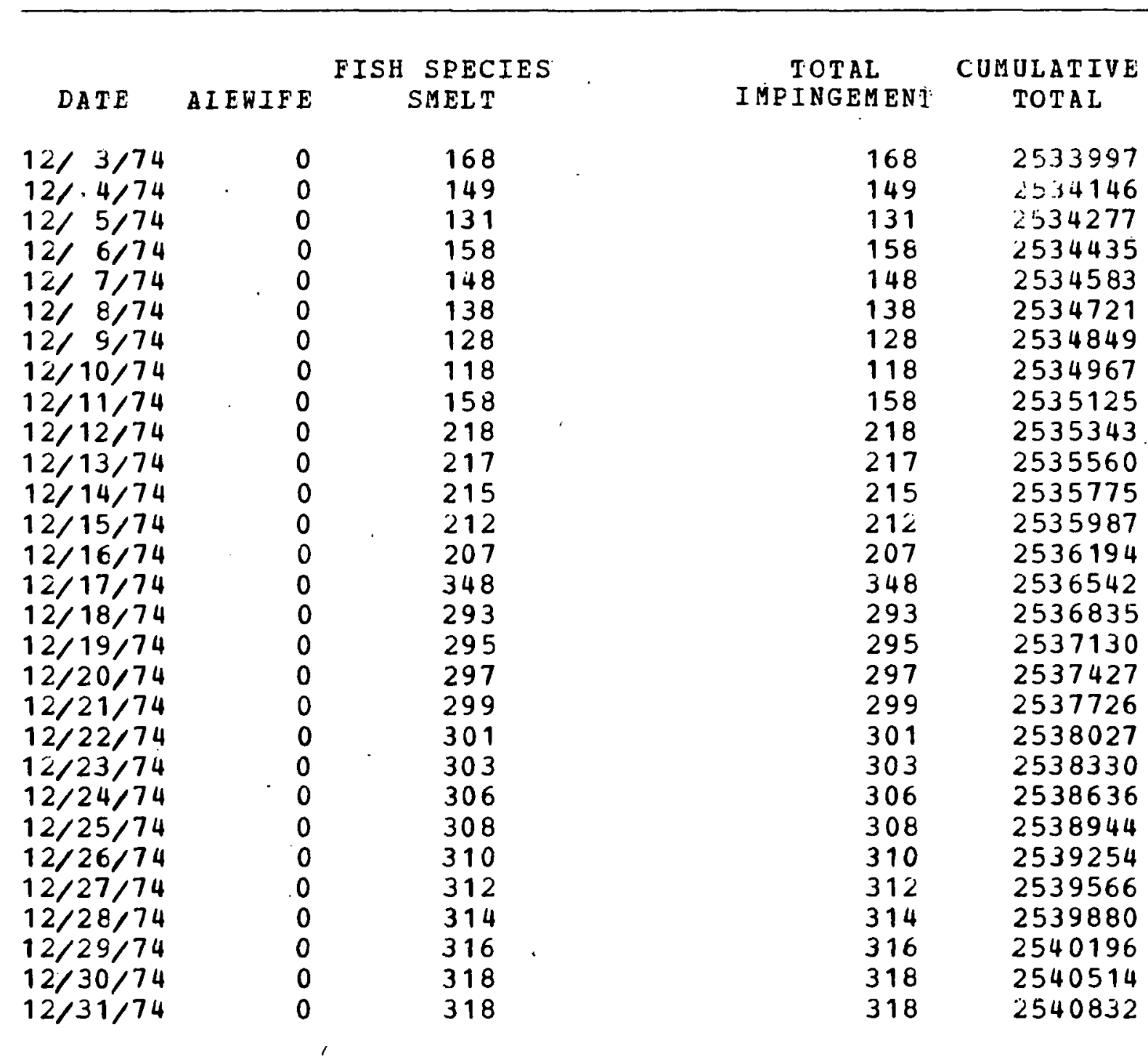




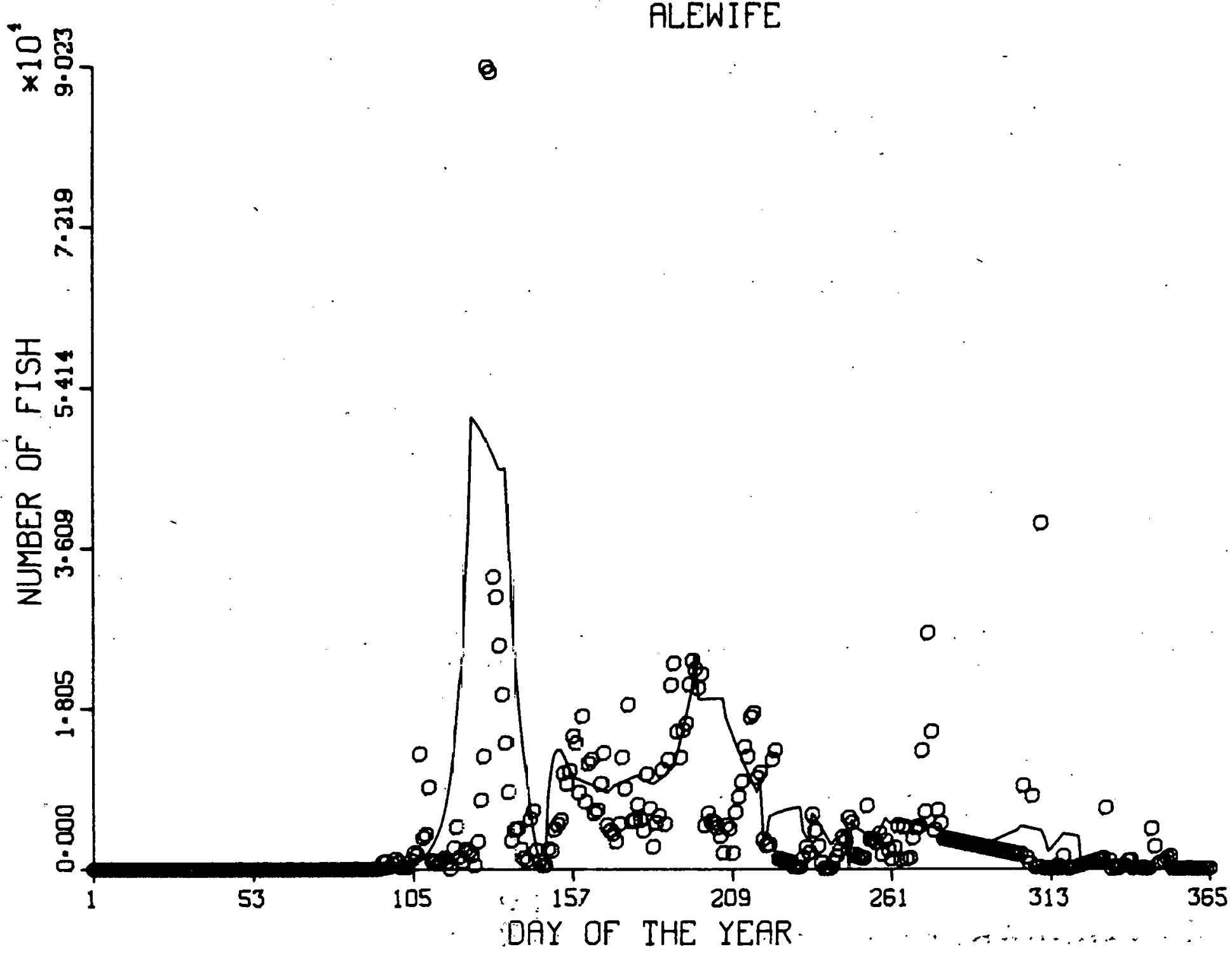

Fig. 15. Predicted Impingement (solid line! for Case III and Observed Impingement (circles) of Alewives at the Zion Station during 1974 (No. of fish/day). 


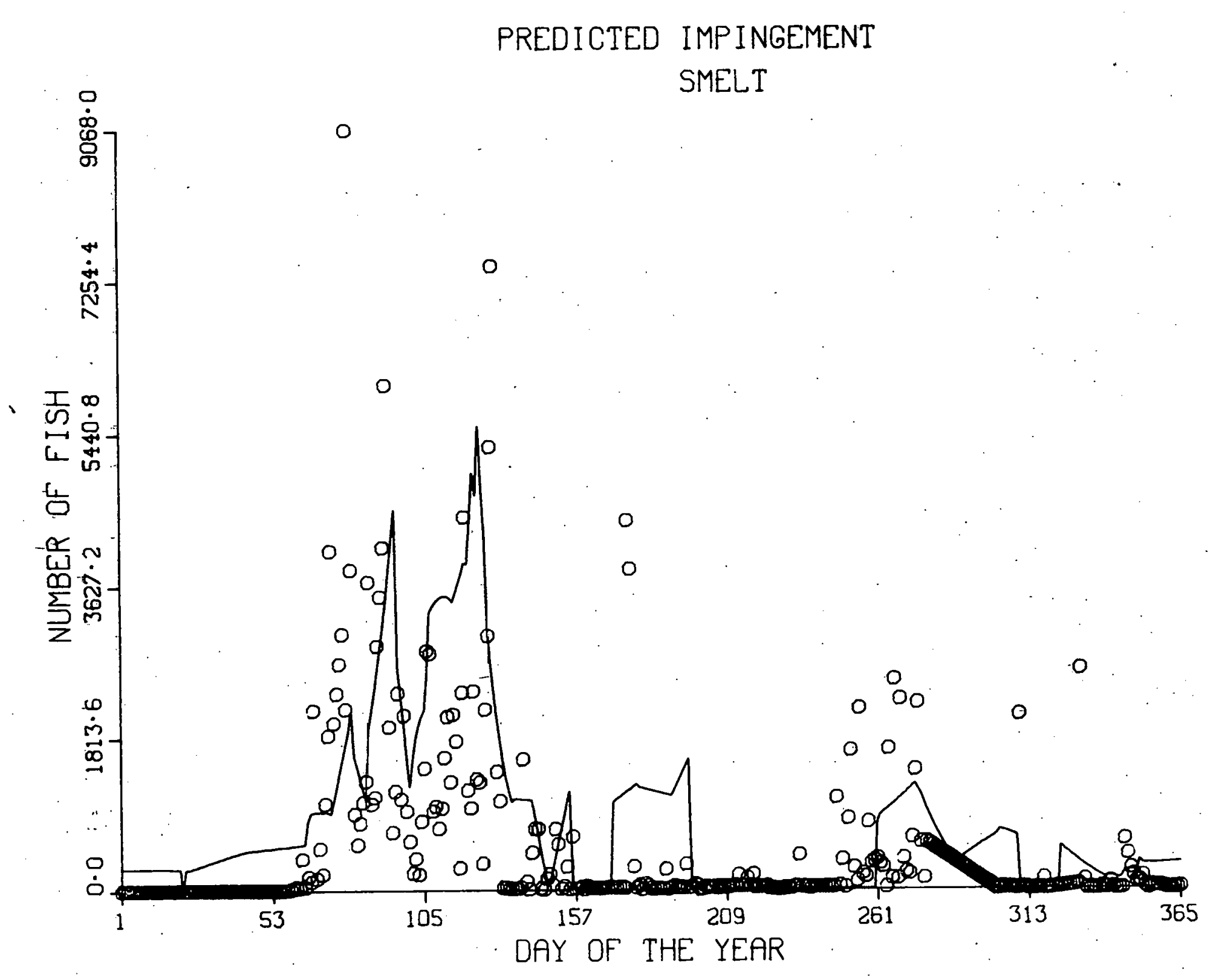

Fig. 16. Predicted Impingement (solid line) for Case III and Observed Impingement (circles) of Smelt at the Zion Station during 1974 (No. of fish/day). 


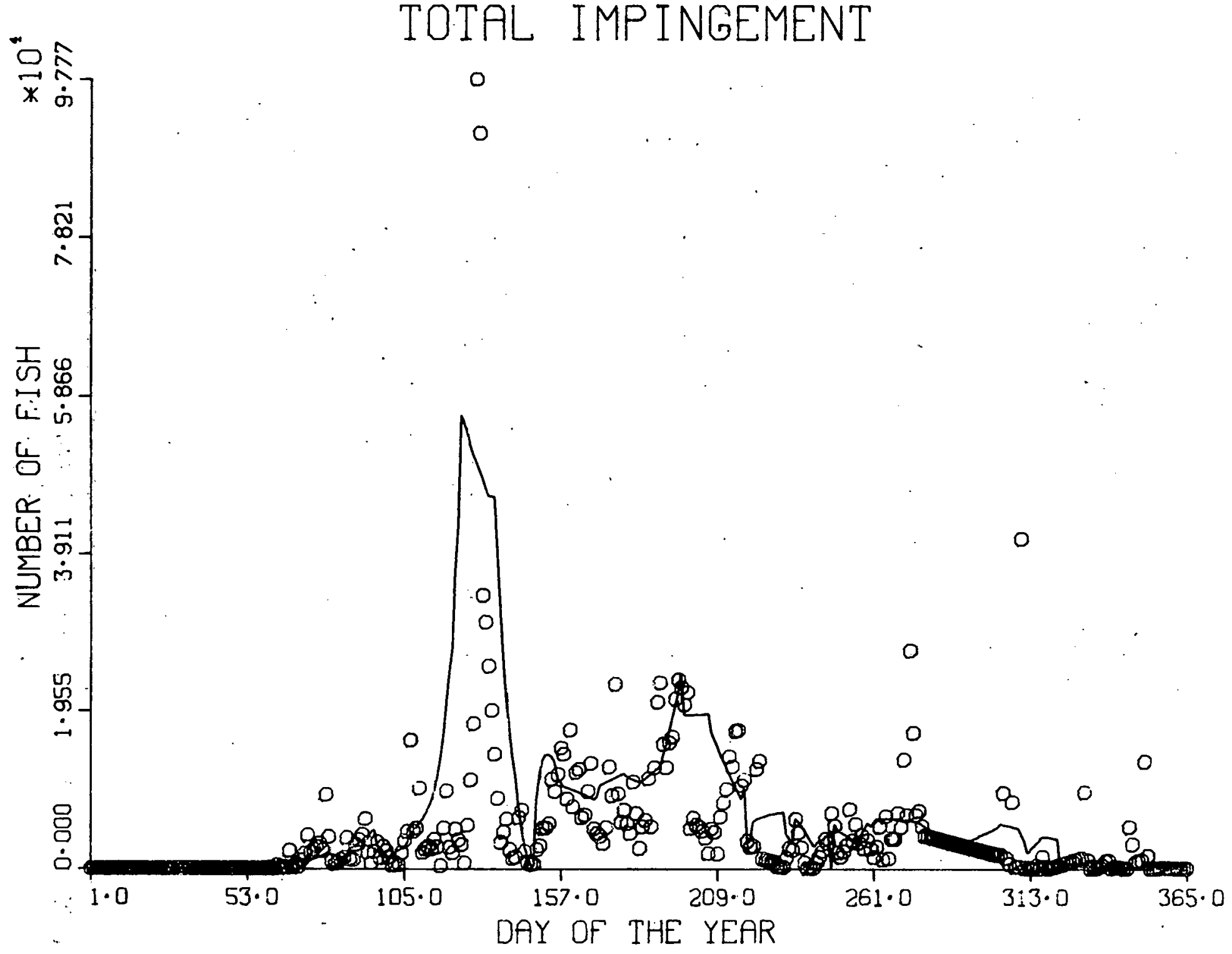

Fig. 17. Predicted Impingement (solid line) for Case III and Observed Impingement (circles) of Both Species at the Zion Station during 197.4 (No. of fish/day). 


\section{ESTIMATED PROBABILITY \\ ALEWIFE}

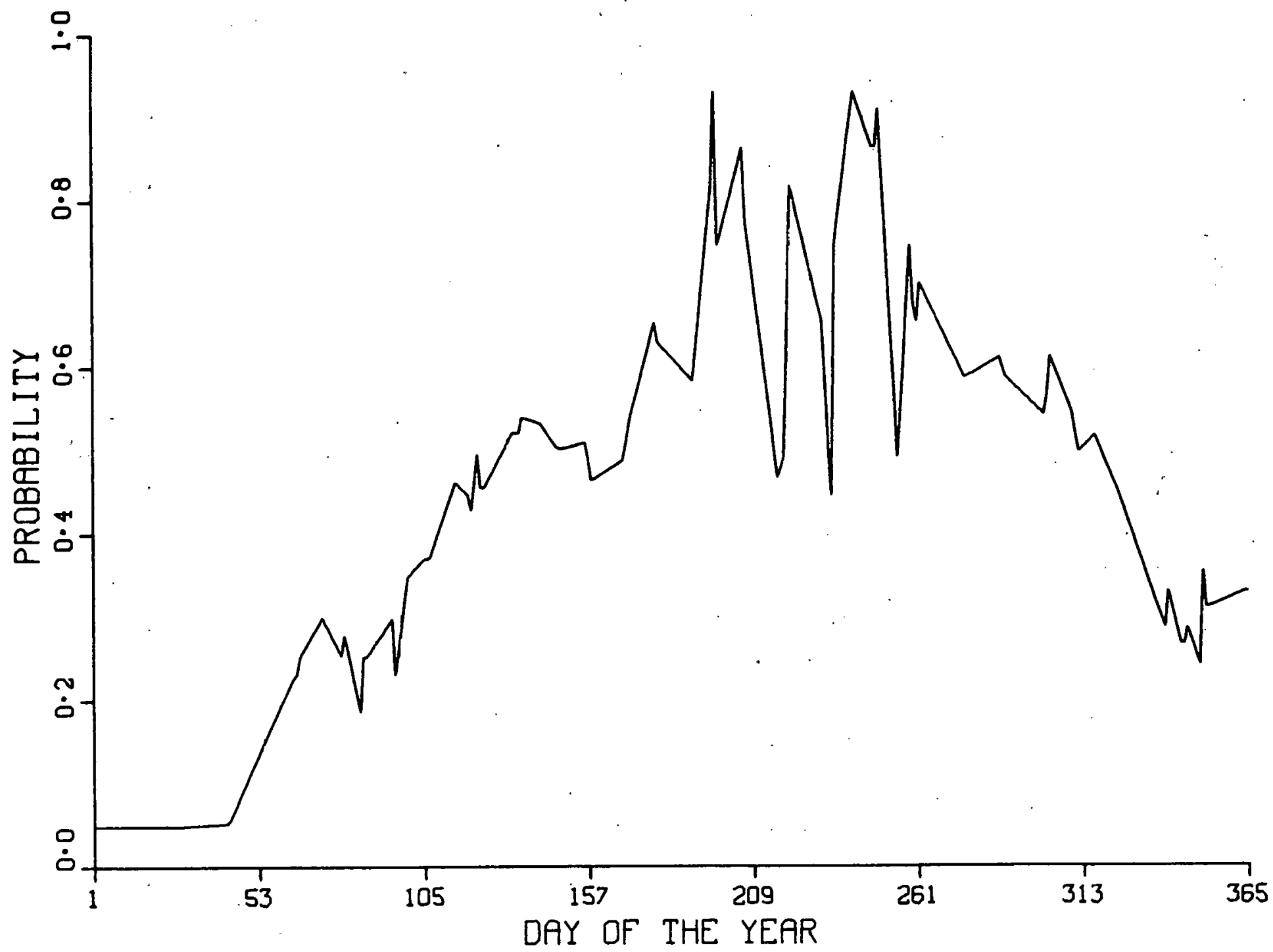

Fig. 18. The Risk of Impingement of Alewives According to the Probability Function under the Conditions of Case III. 


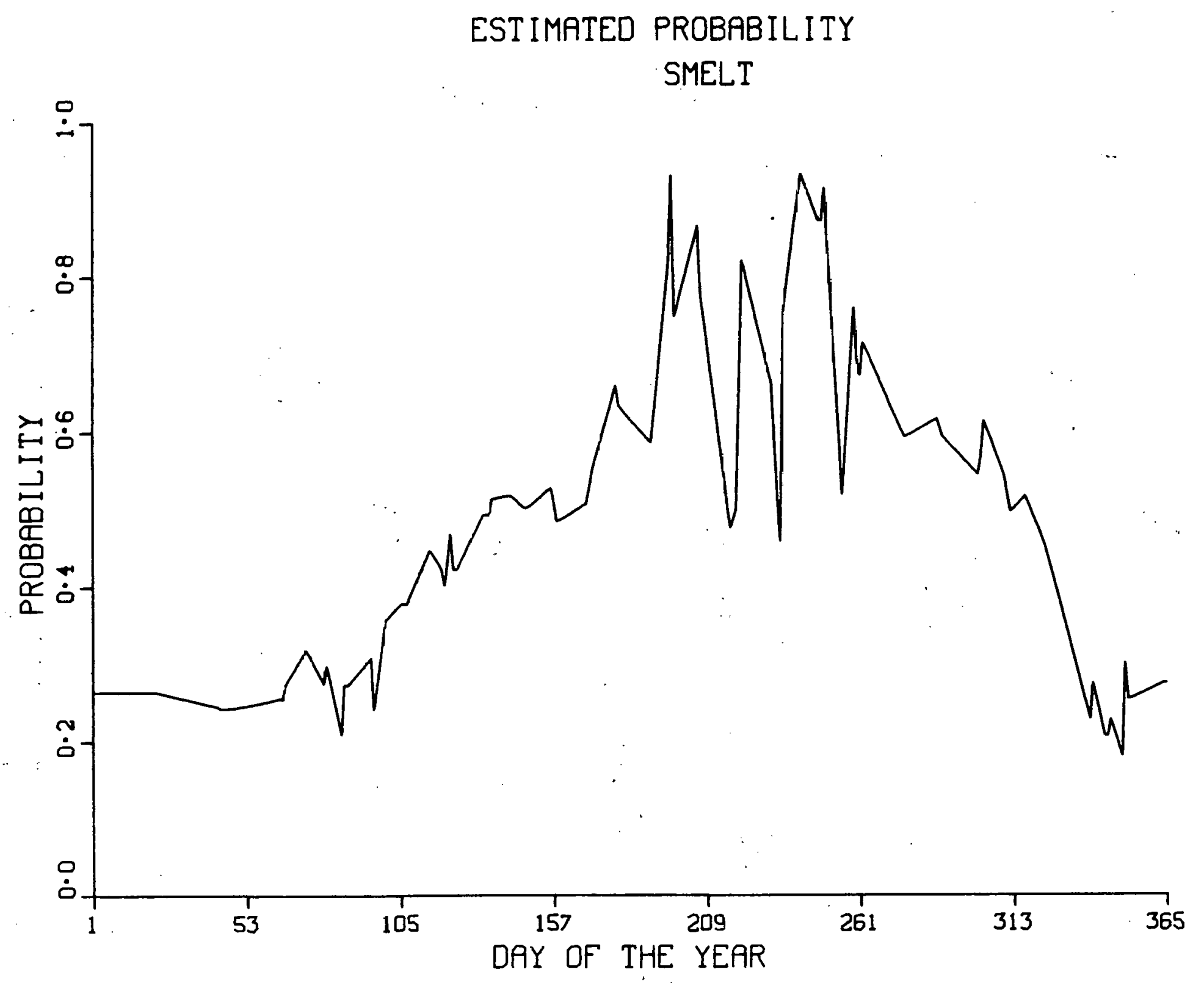

Fig. 19. The Risk of Impingement of Smelt According to the Probability Function under the Conditions of Case III. 
Table 9. Numerical Values for Fish Density and Probability of Impingement for Case III

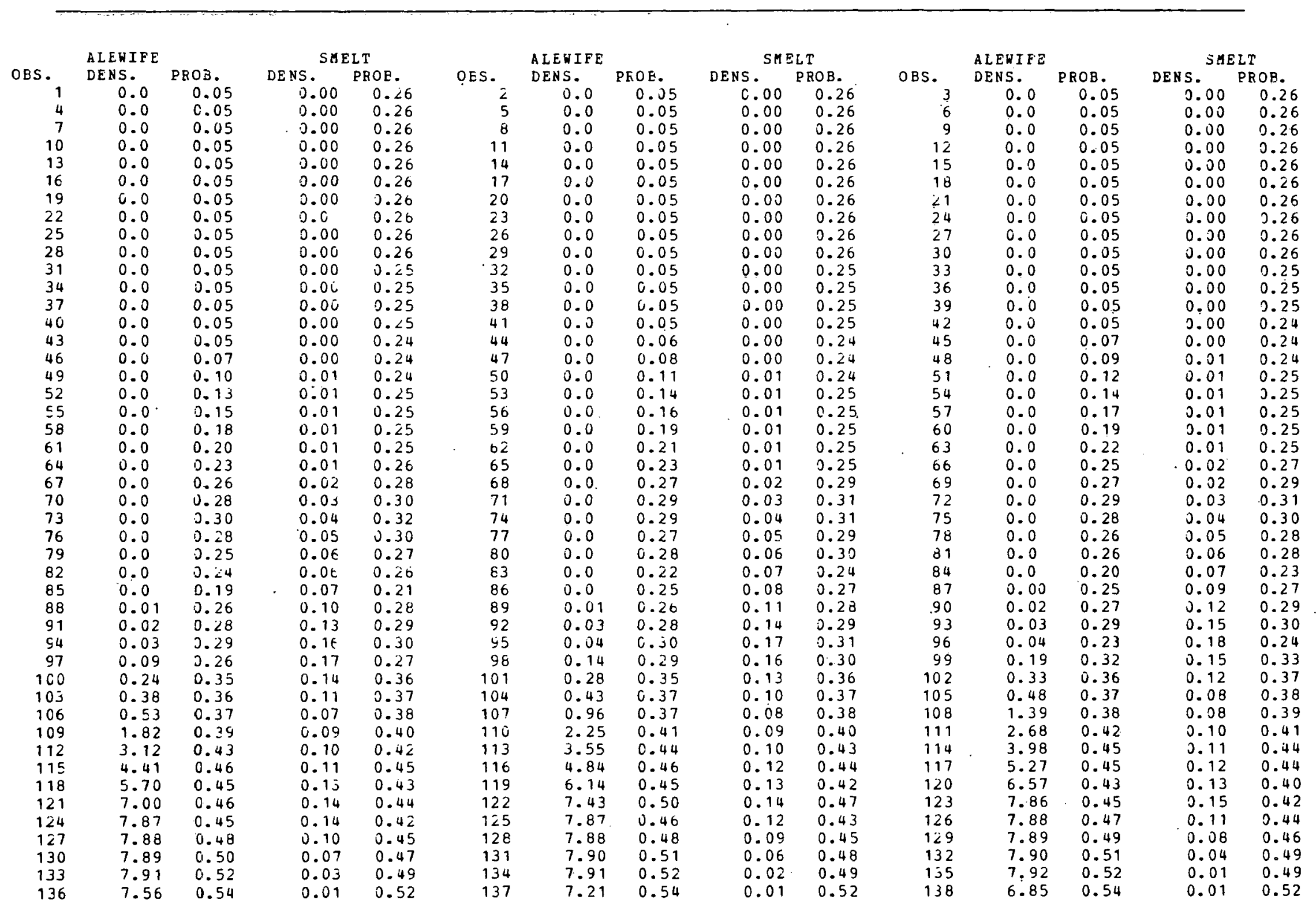


Table 9. Continued

\begin{tabular}{|c|c|c|c|c|c|c|c|c|c|c|c|c|c|c|}
\hline \multirow{3}{*}{ OES. } & \multicolumn{2}{|l|}{ ALEWIPE } & \multicolumn{2}{|c|}{ SMELT } & \multicolumn{3}{|c|}{ A L EW IFE } & \multicolumn{2}{|c|}{ SMEIT } & \multicolumn{3}{|c|}{ ALEWIFE } & \multicolumn{2}{|c|}{ SMELT } \\
\hline & DENS. & PEOB. & DENS. & PROB. & OBS. & DENS. & FECB. & DENS. & PROB. & OBS. & DENS, & PROB. & DENS. & PROB. \\
\hline & 6.49 & 0.54 & 0.01 & 0.52 & 140 & 6.14 & 0.53 & 0.01 & 0.52 & 141 & 5.78 & 0.53 & 0.01 & 0.52 \\
\hline 142 & 5.43 & 0.53 & 0.01 & 0.52 & $14 j$ & 5.07 & 0.53 & 0.01 & 0.52 & 144 & 4.72 & 0.52 & 0.01 & 0.51 \\
\hline 145 & 4.36 & 0.51 & 0.01 & 0.51 & 146 & 4.01 & 0.51 & 0.00 & 0.51 & 147 & 3.65 & 0.50 & 0.00 & 0.50 \\
\hline 148 & 3.29 & 0.50 & 0.00 & 0.50 & 149 & 2.94 & 0.50 & 0.00 & 0.51 & 150 & 2.58 & 0.50 & 0.00 & 0.51 \\
\hline 151 & 2.23 & 0.50 & 0.00 & 0.51 & 152 & 1.87 & 0.51 & 0.00 & 0.52 & $15 j$ & 1.52 & 0.51 & 0.00 & 0.52 \\
\hline $1 \leq 4$ & 1.16 & 0.51 & 0.00 & 0.52 & 155 & 0.80 & 0.51 & 0.00 & 0.53 & 156 & 0.45 & 0.51 & 0.0 & 0.53 \\
\hline 157 & 0.46 & 0.49 & 0.0 & 0.51 & 158 & 0.47 & 0.46 & 0.0 & 0.48 & 159 & 0.48 & 0.47 & 0.0 & 0.49 \\
\hline 160 & 0.49 & 0.47 & 0.0 & 0.49 & 161 & 0.50 & 0.47 & 0.0 & 0.49 & 162 & 0.51 & 0.47 & 0.0 & 0.49 \\
\hline 163 & 0.52 & 0.48 & 0.0 & 0.50 & 164 & 0.53 & 0.48 & 0.0 & 0.50 & 165 & 0.55 & 0.48 & 0.0 & 0.50 \\
\hline 166 & 0.56 & 0.48 & 0.0 & 0.50 & 167 & 0.57 & 0.49 & 0.0 & 0.51 & 168 & 0.58 & 0.49 & 0.0 & 0.51 \\
\hline 169 & 0.59 & 0.51 & 0.0 & 0.53 & $17 \mathrm{C}$ & 0.57 & 0.54 & 0.00 & 0.55 & 171 & 0.56 & 0.55 & 0.00 & 0.57 \\
\hline 172 & 0.54 & 0.57 & 0.00 & 0.58 & 173 & 0.53 & 0.58 & 0.00 & 0.59 & 174 & 0.51 & 0.60 & 0.00 & 0.61 \\
\hline 175 & 0.50 & 0.61 & 0.00 & 0.62 & $17 E$ & 0.48 & 0.62 & 0.00 & 0.63 & 177 & 0.47 & 0.64 & 0.00 & 0.65 \\
\hline 178 & 0.45 & 0.65 & 0.00 & 0.66 & 179 & 0.44 & 0.63 & 0.00 & 0.63 & $18 j$ & 0.42 & 0.63 & 0.00 & 0.63 \\
\hline 181 & 0.41 & 0.62 & 0.00 & 0.62 & $18 \bar{c}$ & 0.39 & 0.62 & 0.00 & 0.62 & 183 & 0.38 & 0.61 & 0.00 & 0.61 \\
\hline 184 & 0.44 & 0.61 & 0.00 & 0.61 & 185 & 0.50 & 0.60 & 0.00 & 0.61 & 186 & 0.56 & 0.60 & 0.00 & 0.60 \\
\hline 187 & 0.63 & 0.60 & 0.00 & 0.60 & $18 \varepsilon$ & 0.69 & 0.59 & 0.00 & 0.59 & 189 & 0.75 & 0.59 & 0.30 & 0.59 \\
\hline 190 & 0.81 & 0.58 & 0.00 & 0.59 & 191 & 0.87 & 0.62 & 0.00 & 0.62 & 192 & 0.93 & 0.66 & 0.00 & 0.66 \\
\hline 193 & 0.99 & 0.70 & 0.00 & 0.70 & 194 & 1.05 & 0.74 & 0.00 & 0.74 & 195 & 1.12 & 0.78 & 0.00 & 0.78 \\
\hline 196 & 1.18 & 0.82. & 0.00 & 0.82 & 197 & 1.24 & 0.93 & 0.0 & 0.93 & 198 & 1.21 & 0.75 & 0.0 & 0.75 \\
\hline 199 & 1.18 & $0.76^{\circ}$ & .0 .0 & 0.76 & $20 \mathrm{C}$ & 1.15 & 0.78 & 0.0 & 0.78 & 201 & 1.12 & 0.79 & $=0.0$ & 0.79 \\
\hline 202 & 1.10 & 0.81 & 0.0 & 0.81 & $20 \equiv$ & 1.07 & 0.82 & 0.0 & 0.82 & 204 & 1.04 & $0.84^{\circ}$ & 0.0 & 0.84 \\
\hline 205 & 1.01 & 0.85 & $0 . c$ & C.85 & $\angle O E$ & 0.98 & 0.87 & 0.0 & 0.87 & 207 & 0.95 & 0.77 & 0.0 & 0.78 \\
\hline 208 & 0.93 & 0.74 & 0.0 & C. 75 & $20 \mathrm{~S}$ & 0.90 & 0.71 & 0.0 & 0.72 & 210 & 0.87 & 0.68 & 0.0 & 0.69 \\
\hline 211 & 0.84 & 0.65 & 0.0 & C. .66 & $21 i$ & 0.81 & 0.62 & 0.0 & $0.63^{\circ}$ & 213 & 0.78 & 0.59 & 0.0 & 0.60 \\
\hline 214 & 0.75 & 0.56 & 0.0 & $i .57$ & 215 & 0.73 & 0.53 & 0.0 & 0.54 & $21 t$ & 0.70 & 0.50 & 0.0 & 0.51 \\
\hline 217 & 0.67 & 0.47 & 0.0 & 0.48 & 218 & 0.64 & 0.48 & 0.0 & 0.49 & 219 & 0.61 & 0.49 & 0.0 & 0.50 \\
\hline 220 & 0.61 & 0.66 & 0.0 & 0.66 & 221 & 0.61 & 0.82 & 0.0 & 0.82 & $22 \bar{z}$ & 0.60 & 0.80 & 0.0 & 0.81 \\
\hline 223 & 0.60 & 0.79 & 0.0 & 0.79 & $\angle 2 L$ & 0.60 & 0.77 & 0.0 & 0.77 & 225 & 0.59 & 0.75 & 0.0 & 0.76 \\
\hline 226 & 0.59 & 0.74 & 0.0 & C. . 74 & 227 & 0.59 & 0.72 & 0.0 & 0.73 & 226 & 0.59 & 0.70 & 0.0 & 0.71 \\
\hline 229 & 0.58 & 0.69 & 0.0 & 0.69 & 250 & 0.58 & 0.67 & 0.0 & 0.68 & 231 & 0.58 & 0.66 & 0.0 & 0.66 \\
\hline 232 & 0.58 & 0.58 & 0.0 & 0.59 & 233 & 0.54 & 0.51 & 0.0 & 0.52 & $2 \leq 4$ & 0.50 & 0.45 & 0.0 & 0.46 \\
\hline 235 & 0.46 & 0.75 & 0.0 & 0.75 & $23 \epsilon$ & 0.42 & 0.76 & 0.0 & 0.78 & 237 & 0.38 & 0.81 & 0.0 & 0.82 \\
\hline 238 & 0.35 & 0.84 & 0.0 & 0.85 & 239 & 0.31 & 0.87 & 0.0 & 0.88 & 240 & 0.27 & 0.90 & 0.0 & 0.91 \\
\hline 241 & 0.23 & 0.93 & 0.0 & 0.94 & 242 & 0.19 & 0.92 & 0.0 & 0.92 & 243 & 0.15 & 0.91 & 0.0 & 0.91 \\
\hline 244 & 0.12 & 0.90 & 0.0 & 0.90 & 245 & 0.08 & 0.69 & 0.0 & 0.89 & $24 \epsilon$ & 0.04 & 0.88 & 0.0 & 0.88 \\
\hline 247 & 0.0 & 0.87 & 0.0 & 0.87 & 248 & 0.00 & 0.87 & 0.0 & 0.87 & 249 & 0.00 & 0.91 & 0.0 & 0.92 \\
\hline 250 & 0.00 & 0.84 & 0.0 & 0.85 & 251 & 0.00 & 0.77 & 0.0 & 0.78 & 252 & 0.00 & 0.70 & 0.0 & 0.72 \\
\hline $2 \leq 3$ & 0.00 & 0.63 & 0.0 & 0.65 & 254 & 0.00 & $0.5 \epsilon$ & 0.0 & 0.59 & 255 & 0.00 & 0.49 & 0.0 & 0.52 \\
\hline 256 & 0.00 & 0.56 & 0.0 & 0.58 & 257 & 0.00 & 0.62 & 0.0 & 0.64 & $2 \leq 8$. & 0.00 & 0.68 & 0.0 & 0.70 \\
\hline $2 \subseteq 9$ & 0.00 & 0.75 & 0.0 & $\dot{\mathrm{u}} .76$ & 260 & 0.00 & 0.68 & 0.0 & 0.69 & $2 \in 1$ & 0.00 & 0.66 & 0.00 & 0.67 \\
\hline 262 & 0.00 & 0.70 & 0.01 & 0.72 & 263 & 0.01 & C. $6 \subseteq$ & 0.01 & 0.71 & 264 & 0.01 & 0.69 & 0.02 & 0.70 \\
\hline 265 & 0.01 & 0.68 & 0.02 & 0.69 & 266 & 0.01 & 0.67 & 0.02 & 0.68 & 26.7 & 0.01 & 0.66 & 0.03 & 0.67 \\
\hline 268 & 0.01 & 0.65 & 0.03 & 0.66 & 269 & 0.01 & 0.64 & 0.04 & 0.65 & 270 & 0.01 & 0.64 & 0.04 & .65 \\
\hline 271 & 0.01 & 0.63 & 0.04 & 0.64 & 272 & 0.01 & 0.62 & 0.05 & 0.63 & $27 j$ & 0.01 & 0.61 & 0.05 & 0.62 \\
\hline 274 & 0.01 & 0.60 & 0.06 & 0.61 & 275 & 0.02 & 0.60 & 0.05 & 0.60 & 276 & 0.02 & 0.59 & 0.05 & 0.59 \\
\hline
\end{tabular}


Table 9. Continued

\begin{tabular}{|c|c|c|c|c|c|c|c|c|c|c|c|c|c|c|}
\hline \multirow{6}{*}{$\begin{array}{r}\text { OES } \\
277 \\
280 \\
283 \\
286\end{array}$} & \multicolumn{2}{|l|}{ ALEWIFE } & \multicolumn{2}{|c|}{ SMELT } & \multicolumn{3}{|c|}{$A L E W I F E$} & \multicolumn{2}{|c|}{ SMELT } & \multicolumn{3}{|c|}{ A LEWIFE } & \multicolumn{2}{|c|}{ SMEL,T } \\
\hline & DENS. & PROB. & DENS. & PROB. & OBS. & DENS. & PRCB. & DENS. & PROB. & OBS. & DENS. & PROB. & DENS. & PROB. \\
\hline & 0.03 & 0.59 & 0.04 & 0.60 & 278 & 0.04 & 0.59 & 0.04 & 0.50 & 279 & 0.04 & 0.59 & 0.04 & 0.50 \\
\hline & 0.05 & 0.60 & 0.03 & 0.60 & 281 & 0.05 & 0.60 & 0.03 & 0.60 & 282 & $\begin{array}{l}0.04 \\
0.06\end{array}$ & 0.60 & 0.02 & 0.50 \\
\hline & 0.07 & 0.60 & 0.02 & 0.61 & 284 & 0.07 & 0.61 & 0.02 & 0.61 & 285 & 0.08 & 0.61 & 0.01 & 0.61 \\
\hline & 0.08 & 0.61 & .0 .01 & 0.62 & 287 & 0.09 & 0.61 & 0.00 & 0.62 & 288 & 0.09 & 0.60 & 0.00 & 0.61 \\
\hline 289 & 0.09 & 0.59 & 0.00 & 0.59 & 290 & 0.08 & 0.56 & 0.00 & 0.59 & 291 & 0.08 & 0.58 & 0.00 & 0.59 \\
\hline 292 & 0.08 & 0.58 & 0.00 & 0.50 & 203 & 0.08 & 0.57 & 0.00 & 0.58 & 294 & 0.07 & 0.57 & 0.00 & 0.57 \\
\hline 295 & 0.07 & 0.57 & 0.00 & 0.57 & 296 & 0.07 & 0.56 & 0.00 & 0.57 & 297 & 0.07 & 0.56 & 0.00 & 0.56 \\
\hline 298 & 0.06 & 0.55 & 0.00 & 0.50 & 299 & 0.06 & 0.55 & 0.00 & 0.55 & 300 & 0.06 & 0.55 & 0.00 & 0.55 \\
\hline 301 & 0.06 & 0.54 & 0.00 & 0.55 & 302 & 0.05 & 0.57 & 0.00 & 0.57 & 303 & 0.05 & 0.61 & 0.00 & 0.52 \\
\hline 304 & 0.05 & 0.60 & 0.00 & 0.60 & 305 & 0.05 & 0.55 & 0.00 & 0.59 & 306 & 0.04 & 0.58 & 0.00 & 0.58 \\
\hline 307 & 0.04 & 0.57 & 0.00 & 0.57 & 308 & 0.04 & 0.50 & 0.00 & 0.56 & 309 & 0.04 & 0.55 & 0.00 & 0.55 \\
\hline 310 & 0.03 & 0.54 & 0.0 & 0.54 & 311 & 0.03 & $c .52$ & C. 0 & 0.52 & 312 & 0.03 & 0.50 & 0.0 & 0.50 \\
\hline 313 & 0.03 & 0.50 & 0.0 & 0.50 & $j 14$ & 0.02 & 0.51 & 0.0 & 0.51 & 315 & 0.02 & 0.51 & 0.0 & 0.51 \\
\hline 316 & 0.02 & 0.51 & 0.0 & 0.51 & 317 & 0.02 & 0.52 & 0.0 & 0.52 & 318 & 0.01 & 0.51 & 0.0 & 0.51 \\
\hline 319 & 0.01 & 0.50 & 0.0 & 0.50 & 220 & 0.01 & 0.49 & 0.0 & 0.49 & 321 & 0.01 & 0.48 & 0.0 & 0.48 \\
\hline 322 & 0.00 & 0.47 & 0.0 & 0.47 & 323 & 0.0 & 0.45 & 0.0 & 3.46 & 324 & 0.0 & 0.45 & 0.00 & 0.45 \\
\hline 325 & 0.0 & 0.44 & 0.00 & 0.44 & $3 \ddot{26}$ & 0.0 & 0.43 & 0.00 & 0.42 & 327 & 0.0 & 0.42 & 0.00 & 0.41 \\
\hline 328 & C. 0 & 0.41 & 0.00 & 0.39 & 329 & 0.0 & 0.40 & 0.00 & 0.38 & 330 & 0.0 & 0.39 & 0.00 & 0.36 \\
\hline 331 & 0.0 & 0.37 & 0.00 & 0.35 & 332 & 0.0 & 0.36 & 0.00 & 0.33 & 333 & 0.0 & 0.35 & 0.00 & 0.32 \\
\hline 334 & 0.0 & 0.34 & 0.00 & 0.30 & 335 & 0.0 & 0.33 & 0.00 & 0.29 & 336 & 0.0 & 0.32 & 0.00 & 0.27 \\
\hline 337 & 0.0 & 0.31 & 0.00 & 0.26 & 338 & 0.0 & 0.30 & 0.00 & 0.24 & 339 & 0.0 & 0.29 & 0.00 & 0.23 \\
\hline 340 & 0.0 & 0.33 & 0.00 & 0.28 & 341 & 0.0 & 0.31 & 0.00 & 0.26 & 342 & 0.0 & 0.30 & 0.00 & 0.24 \\
\hline 343 & C. 0 & 0.28 & 0.00 & 0.22 & 344 & 0.0 & 0.27 & 0.00 & 0.21 & 345 & 0.0 & 0.27 & 0.00 & 0.21 \\
\hline 346 & 0.0 & 0.29 & 0.00 & 0.22 & 347 & 0.0 & 0.25 & 0.00 & 0.22 & 348 & 0.0 & 0.26 & 0.00 & 0.20 \\
\hline 349 & 0.0 & 0.25 & 0.00 & 0.19 & 350 & 0.0 & 0.24 & 0.00 & 0.18 & 351 & 0.0 & 0.35 & 0.00 & 0.30 \\
\hline 352 & 0.0 & 0.31 & 0.00 & 0.25 & 353 & 0.0 & 0.31 & 0.00 & 0.26 & 354 & 0.0 & 0.31 & 0.00 & 0.26 \\
\hline 355 & 0.0 & 0.32 & 0.00 & 0.26 & 356 & 0.0 & 0.32 & 0.00 & 0.26 & 357 & 0.0 & 0.32 & 0.00 & 0.26 \\
\hline 358 & 0.0 & 0.32 & 0.00 & $0 . \approx 6$ & 359 & 0.0 & 0.32 & 0.00 & 0.27 & 360 & 0.0 & 0.32 & 0.00 & 0.27 \\
\hline $3 \in 1$ & 0.0 & .0 .33 & 0.40 & 0.27 & $3 \in 2$ & 0.0 & 0.33 & 0.00 & 0.27 & $36 j$ & 0.0 & 0.33 & 0.00 & 0.27 \\
\hline 364 & 0.0 & 0.33 & 0.00 & 0.28 & 365 & 0.0 & 0.33 & 0.00 & $0.2 B$ & & & & & \\
\hline
\end{tabular}




\subsection{COMPARISON AND DISCUSSION OF THE THREE CASES}

By comparing the three cases we find that the exponential model seems to predict fish-impingement values that generally behave in the manner of observed fish impingements. The most important aspect in these calculations arises from the fish-density observations, followed by the water-temperature effects and then the length-frequency classes. On the whole we find that the model formulation and computations are in agreement with observed fish impingements.

The low correlation between computed fish-impingement values and those actually observed is due primarily to the separation in time between fish density measurements (trawls) and impingement data per se. Also, the frequency of trawls and the need to interpolate makes for further uncertainty and mismatch. It is expected that the model formulation will perform adequately for predicting fish impingement at cooling-water intakes if much more frequent fish-abundance obșervations are available; for instance, every week or every third day. It is our opinion that improvements in the means for measuring the fish abundance nondestructively and accurately are necessary if predictions are to be improved. Increased accuracy of the length-class distribution that will result in better defined probabilities is needed before we can advance the modeling formulation, to improve its predictive capabilities. 


\section{DESCRIPTION AND DOCUMENTATION OF THE SOFTWARE SYSTEM}

The Argonne Fish-Impingement Model Simulator (AFIMS) is a software package for implementing the mathematical models for predicting fish impingement at cooling water intakes. A user can select either the linear or the exponential form of the fish-density function in the models. User-supplied parameters, such as fish densities derived from trawl catches, fish-behavior characteristics, water temperatures, and water pumping rates, are necessary inputs and the choice of the model or a function sometimes depends on the data the user can provide. The modular construction of AFIMS, which provides both tabular and graphical outputs, consists of a main program, SIMULATE, and five subroutines-VOLUME, NUMBER, OUTPUT, IPLOT, and SCALE. A special purpose BLOCK DATA subroutine is also used to initialize variables and arrays. A listing of the FORTRAN source statements is given in Table 10.

The subroutine VOLUME reads in and interpolates the input data on the volume of water pumped and the water temperature recorded. The NUMBER subroutine reads in the fish-density and the length-frequency distribution data to generate probability values and daily fish-density values. Subroutine OUTPUT can then be used to print out tables of the daily fish-impingement values, and the graphical output may be generated by the subroutine IPLOT, which uses subroutine SCALE to prepare the axes for the plots.

The input card types A-J are used to fix the parameters of the model and the simulation instructions for the software system. Card types 1-3 are used to input the data on the site-specific, time-dependent, fisheries observations.

\subsection{VARIABLES USED IN "COMMON" BLOCKS}

There are a number of labeled COMMON blocks which are used in the software system; i.e.: 
COMMON/REFER/

$* I \operatorname{CODE}(I, J): J^{\text {th }}$ species label

*LABLE (10): title of the output

*IBEG,IEND: beginning and ending days of fish-impingement simulation $\operatorname{QTEMP}(I):$ temperature in ${ }^{\circ} \mathrm{C}$ for the $I^{\text {th }}$ day.

COMMON/CALC/

FISH $(I, J)$ : fish density for the $I^{\text {th }}$ day for the $J^{\text {th }}$ species

FPROB $(I, J)$ : probability of impingement for the $I^{\text {th }}$ day for the $J^{\text {th }}$ species $\operatorname{VOLUM}(I)$ : volume of water used during the $I^{\text {th }}$ day, given in millions of gallons per minute and converted internally to cubic feet per second $\operatorname{INDX}(I)$ : Julian day of. $I^{\text {th }}$ observation

IDAYS $(K)$ : cumulative number of days in the year up to the $K^{\text {th }}$ monch *NUM: number of species (integer values 1,2 , or 3 only) *IYR: calendar year for which simulation is done (last two digits only) NCL $(J)$ : number of length classes for species $J$ (integer values $1,2,3$, 4,5 , or 6 on $1 y$ )

*IFLAG(3): used to suppress selected factors in the model

If $\operatorname{IFLAG(1)}=1$, water temperature is not used to calculate probability

If IFLAG(3) = 1 , fish length is not used to calculate probability

IFLAG(2) is an extra element that was used in the model validation effort, but is no longer nccded.

\section{COMMON/LONG/}

$\operatorname{XLEN}(I, J, K)=$ relative frequency of occurrence of length class $K$ for species .T on day $I$

*YLENB $(\mathrm{J}, \mathrm{K})$ : smallest length in class $\mathrm{K}$ for species $\mathrm{J}$

*YLEND $(\mathrm{J}, \mathrm{K})$ : largest length in class $\mathrm{K}$ for species $\mathrm{J}$

\section{COMMON/FOROUT/}

$\operatorname{IMPING}(\mathrm{K}, \mathrm{J})$ : predicted impingement for the $I^{\text {th }}$ day for the $\mathrm{J}^{\text {th }}$ species FPLANT $(J, L)$ : site-specific correction factor for species $J$ in season $L$

Variables flagged with an * are required input. For variables flagged with an @, values must be provided for some observations throughout the year; 
values for those days for which there are no data are then obtained by linear interpolation from values that are provided as inputs.

\subsection{MAIN PROGRAM "SIMULATE"}

The main program consists of 152 statements, given by card numbers 1 through 152 in Table 10. It reads the general simulation parameters. It uses VOLUME and then NUMBER to read the remaining data and to estimate the probabilities. Then it calculates the predicted impingement according to the desired model and calls OUTPUT to print the results. The main program may also use IPLOT to plot the predicted values and a scatter of the observed. impingements.

\subsubsection{Input to SIMULATE}

(a) ICODE (Card type A) (10A4)

Species names (up to 8 characters 1ong) for each of the NUM species.

(b) LABLE

(Card type B)

Up to 40 alphanumeric characters to be used as heading on the output tables.

(c) NUM, ISWTCH, JFLAG, IBEG, IEND, NCL, (Card type C) $(3(I 1,1 X), 2(I 3, I X), 3(I 1,1 X))$

NUM specifies the number of species for which fish-impingement calculations are to be made.

ISWTCH determines the model to be used. If ISWTCH $=1$, the exponential model is used; if ISWTCH $=2$, the linear model is used.

JFLAG determines the plot option. If JFLAG $=2$, no plotting is done. If JFLAG $=1$, observed data for the entire year must be read in from logical unit 14 and are shown as a scatter of points in the plot of predicted impingement. . If JFLAG $=0$, no observed data are available and only a predicted impingement plot is prepared. There is a plot for each of the NUM species and one for total impingement. 
(d) $(\operatorname{ISEAS}(\mathrm{J}, \mathrm{L}), \mathrm{L}=1,4), \mathrm{J}=1, \mathrm{NUM}) \quad$ (Card type D)

$(12(13,1 \mathrm{X}))$

ISEAS describes the species-specific seasons. ISEAS $(\mathrm{J}, \mathrm{L})=$ the last day of season L for species $J$.

(e) ((FPlant $(\mathrm{J}, \mathrm{L}), \mathrm{L}=1,4), \mathrm{J}=1$, NUM) (Card type $\mathrm{E})$

$(4(E 8.2,1 X))$

Plant-specific seasonal correction factors for each species. One data card is required for each species.

(f) FLEMDA (Card type F)

$(6 \mathrm{X}, 3(\mathrm{E} 14.8,1 \mathrm{X}))$

If the exponential model is used, FLEMDA(J) = transfer coefificient for species $\mathrm{J}$.

(g) If JFLAG $=1$ then the main program reads in $(\operatorname{FORM}(I), I=1,10) \quad$ (Card type $G$ ) (10A4)

Format to specify the fields for observed impingement values that are read in from logical unit 14. Any of the FORTRAN-allowed REAL formats can be used.

\subsubsection{Output Produced by SIMULATE}

All the input data are echoed in output tables. One table is generated as outputs with extensive labels identifying the input data. Examples of this output table is Table 1 in Section 3.

\subsection{SUBROUTINE "VOLUME"}

VOLUME is 1isted as card numbers 153 through 205 in Table 10. The subroutine VOLUME is used to read in the water volume pumped and temperature data for the available observations at several time points in the year. Linear interpolation is used to generate the values for the days when observations are not available. 


\subsubsection{Input Required by VOLUME}

MO, IDAY, VOL, TEMPER

(Card type 1)

$(2 \mathrm{I} 2, \mathrm{~F} 8.0, \mathrm{~F} 4.0)$

MO $=$ month of observation, IDAY = day of month, VOL = volume in millions of gallons per minute, TEMPER = temperature in ${ }^{\circ} \mathrm{C}$.

VOLUME stops reading data when a value of 99 is read for MO. Therefore, the input stream of this data must end with a record with 99 in columns 1 and 2 .

\subsubsection{Output Produced by VOLUME}

There is no output generated by this subroutine. The generated data on water volume pumped and water temperature are printed out by the subroutine OUTPUT.

\subsection{SUBROUTINE "NUMBER"}

NUMBER consists of 154 FORTRAN statements, listed as card numbers 206 through 359 in Table 10. In this subroutine, model specification parameters and data on fish abundance, fish length, and frequency distribution are read in from logical unit 5. Up to 50 data points can be provided as inputs. These data are used to generate linearly interpolated daily observations. Fish-impingement probability values are also calculated in card numbers 317343 from the inputs to this subroutine and from values created in subroutine VOLUME.

\subsection{1; Input Required by NUMBER}

There is a sequence of formatted inputs that are needed data. These are described in the order of the input stream to the subroutine.
(a) $\operatorname{TMIN}(\mathrm{J}), \operatorname{XLMIN}(\mathrm{J}), \operatorname{ImAX}(\mathrm{J}), \operatorname{XIMAX}(\mathrm{J})$
(Card type $\mathrm{H}$ ) $(4 \mathrm{~F} 4.0)$ 


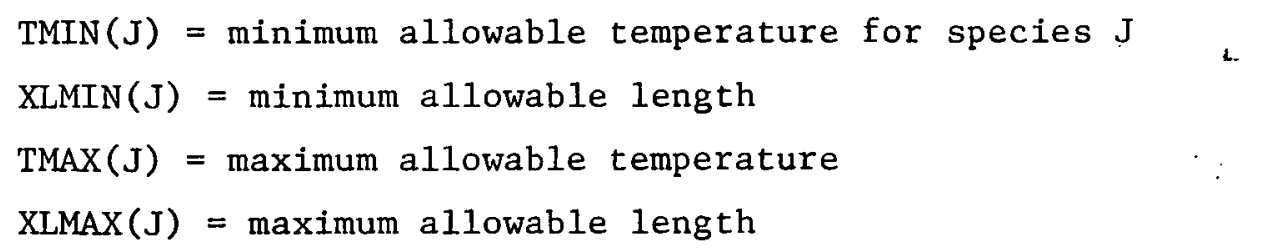

(b) $(\operatorname{YLENB}(J, L), L=1, \operatorname{NCL}(J)) \quad$ (Card type I) .

(6F4.0) This variable reads in the beginning length values for each of the NCL $(J)$ classes for the $J^{\text {th }}$ species.

(c) $(\operatorname{YLEND}(\mathrm{J}, \mathrm{L}), \mathrm{L}=1, \operatorname{NCL}(\mathrm{J})) \quad$ (Card type $\mathrm{J})$.

(6F4.0) This variable reads in the ending length values for each of the NCL(J) classes of the $\mathrm{J}^{\text {th }}$ species.

For each observation:

(a) IMON, IDAY, IYR, NWIDTH, NDEPTH, NSPEED, NTIME (Card type 2) $(6 \mathrm{I} 2, \mathrm{I} 3)$

IMON, IDAY, IYR = date of observation, converted to IND

NWIDTH = diameter of the trawling gear in feet

NDEPTH = length of the trawling gear in feet

NSPEED = travel speed used in $\mathrm{ft} / \mathrm{sec}$.

NTIME = time duration of the trawl in seconds

(b) For each species, J

FISH (IND, J), (XLEN(IND, J, L), L $=1, \operatorname{NCL}(J)) \quad$ (Card type 3)

$(\mathrm{F} 10.2,1 \mathrm{X}, 11 \mathrm{X}, 6(\mathrm{~F} 5.2,1 \mathrm{X}))$

\subsubsection{Output Produced by NUMBER}

A11 the input data are echoed in a table labeled "Input Parameter Specification". Another table labeled "Input Data" lists the input data on the trawl catches. Tables 1-2 in Section 3 are examples of the two types of output tables.

\subsection{SUBROUTINE "OUTPUT"}

This subroutine is listed as card numbers 360 through 512 in Table 10. The subroutine OUTPUT prints the tables of daily predicted fish impingements 
for NUM species and the total of all species. The dafly fish densities and the probabilities of impingement are printed out in another set of tables. Duplicates of these results are also written out to disk files 11 and 12 for permanent storage and later use.

The output produced are tables of:

(a) volume and temperature data for the year (printed) (Example: Table 3 in Section 3)

(b) flsh densities, estimated probabilities, volume and temperature data (unit 12)

(c) predicted impingement (printed and written to unit 11) (Example: Table 4 in Section 3)

(d) fish densities and estimated probabilities (printed) (Example: Table 5 in Section 3 )

\subsection{SUBROUTINE "IPLOT" (JFLAG, FORM)}

IPLOT is given by card numbers 513 through 669 in Table 10. The subroutine IPLOT is optionally used to produce graphical outputs. The possible plots are the following:

(a) for each species

(ii) estimated probability (Example: Fig. 8 in Section 3)

(iii) predicted impingement (Example: Fig. 5 in Section 3)

(b) water volume pumped (Example: Fig. 2 in Section 3)

(c) water temperature (Example: Fig. 1 in Section 3)

(d) predicted total impingement (Example: Fig. 7 in Section 3)

If JFLAG $=1$, observed impingement for every day of the year is read from unit 14 according to the format specifications stored in FORM. It is read in the order: total impingement, species 1, species 2, etc. These observed values are superimposed as a scatter on the plots of predicted impingement for each of the NUM species and the total impingement. 
4.7 SUBROUTINE "SCALE". (A, M, N, X, Y)

The subroutine SCALE is used by IPLOT to set up the plot axes. It is listed as card numbers 670 through 689 in Table 10. It assigns to $X$ the minimum of $A(M)$ through $A(N)$ and to $Y$ the maximum.

\subsection{SUBPROGRAM "BLOCK DATA"}

The BLOCK DATA subprogram is given as card numbers 690.through 700 in Table 10. It is used to initialize some of the arrays in COMMON. 
Table 10. The FORTRAN Source Listing and Input Data for the AFIMS

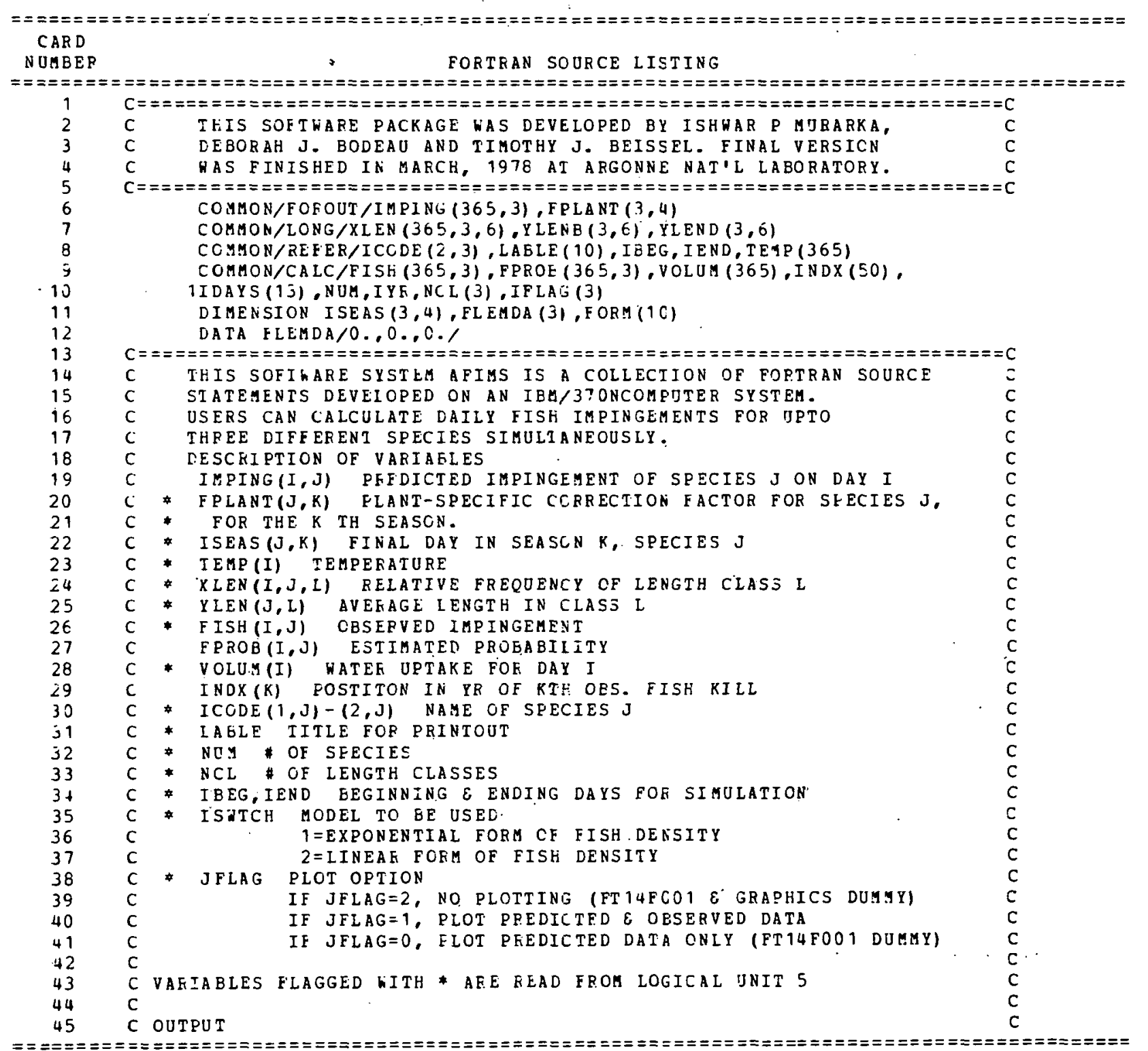




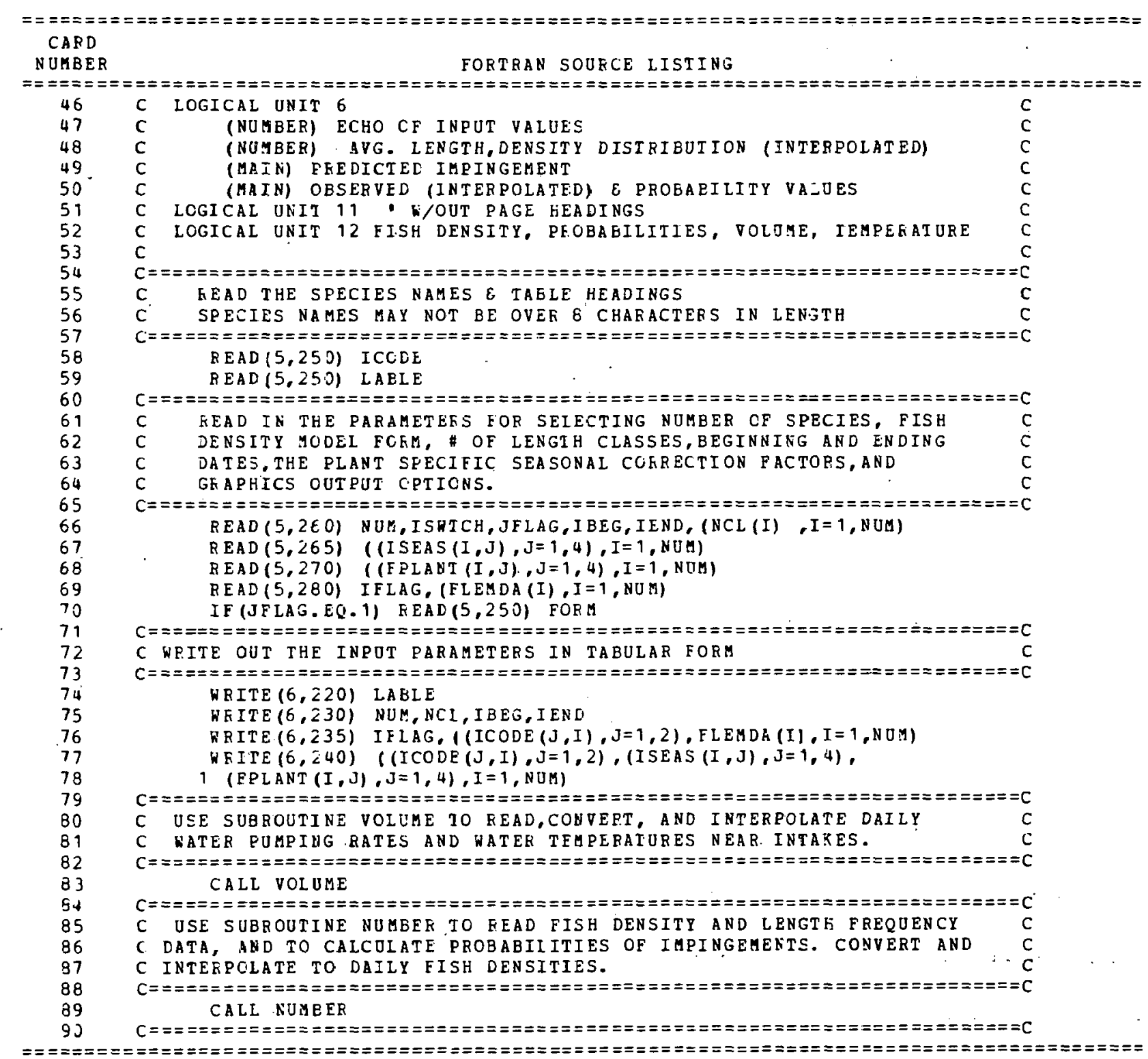




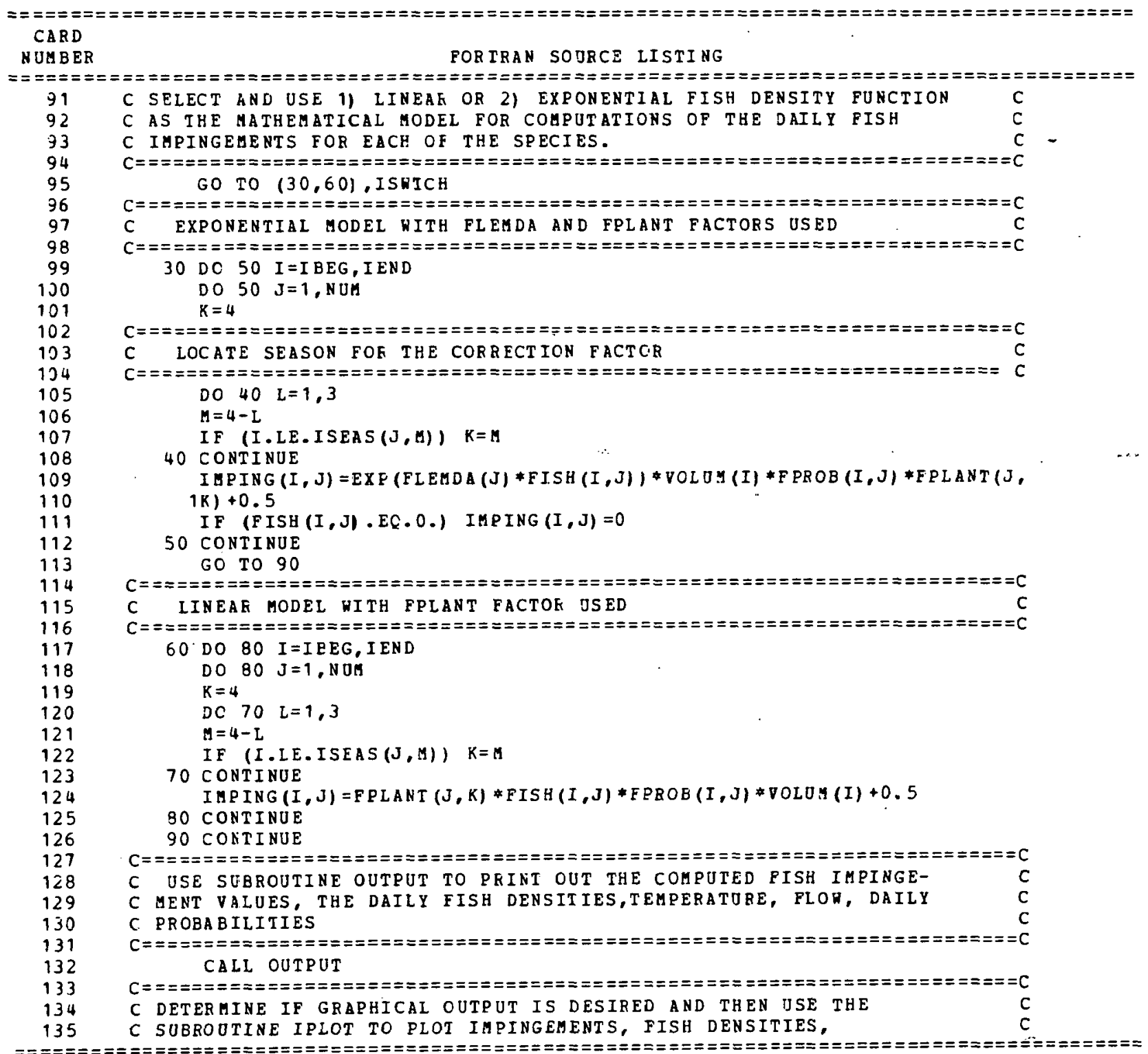


Table 10. Continued

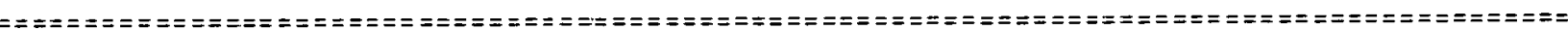

CAPD

NUIBET

FORTEAN SCUFCE LISTINO

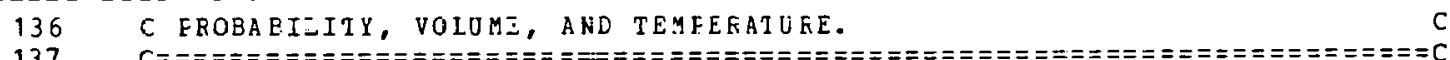

138 IF (JFLAG.NE.2) CALL IPLOT:JFLAG,FORM)

138 IF (JFLAS.NE.2) EALL IPLOT:JFLAG,FORM)

220 FORYAT ( 1 H $1 / 18 X$. 'INPUT PARAMETEE SPECIFICATIONS $113 \mathrm{X}, 10 \mathrm{~A} 4 / /)$

30 FORAAT(" \# OF SEICIES \# OF LENGTH CLASSES BEGINNING

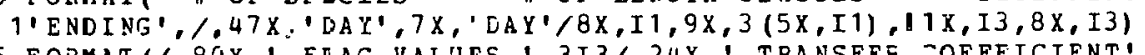

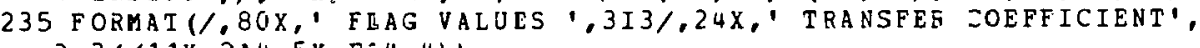

d $3\left(111 X, 2 A 4,5 X, E^{-4} 4,4\right)$

240 FORMAT $/ /$ SEASON END DAYS', 10X,'SEASONA: CORRECIION FACT

1ORS'/3 $(/ 1 X, 2$ A $4,1 \overline{8}, 414,2 X, 4(E 8.2,2 X) 1)$

250 FORAAT $(1044)$

260 FORMAT $(3(I:, 1 X:, 2(I 3,1 X), 3(I 1,1 X))$

26 FORMAT $(12(1 \dot{3}, 13) \hat{)}$

27 C. FORMAT $(4(E 8.2, I X))$

280 F ORIA T $(3(I, 1 \mathrm{X}, .3(\equiv 14.8,1 \mathrm{X}))$

END

152

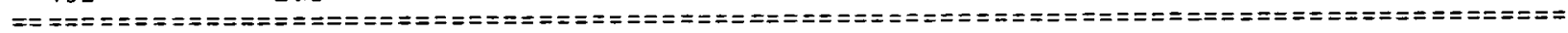




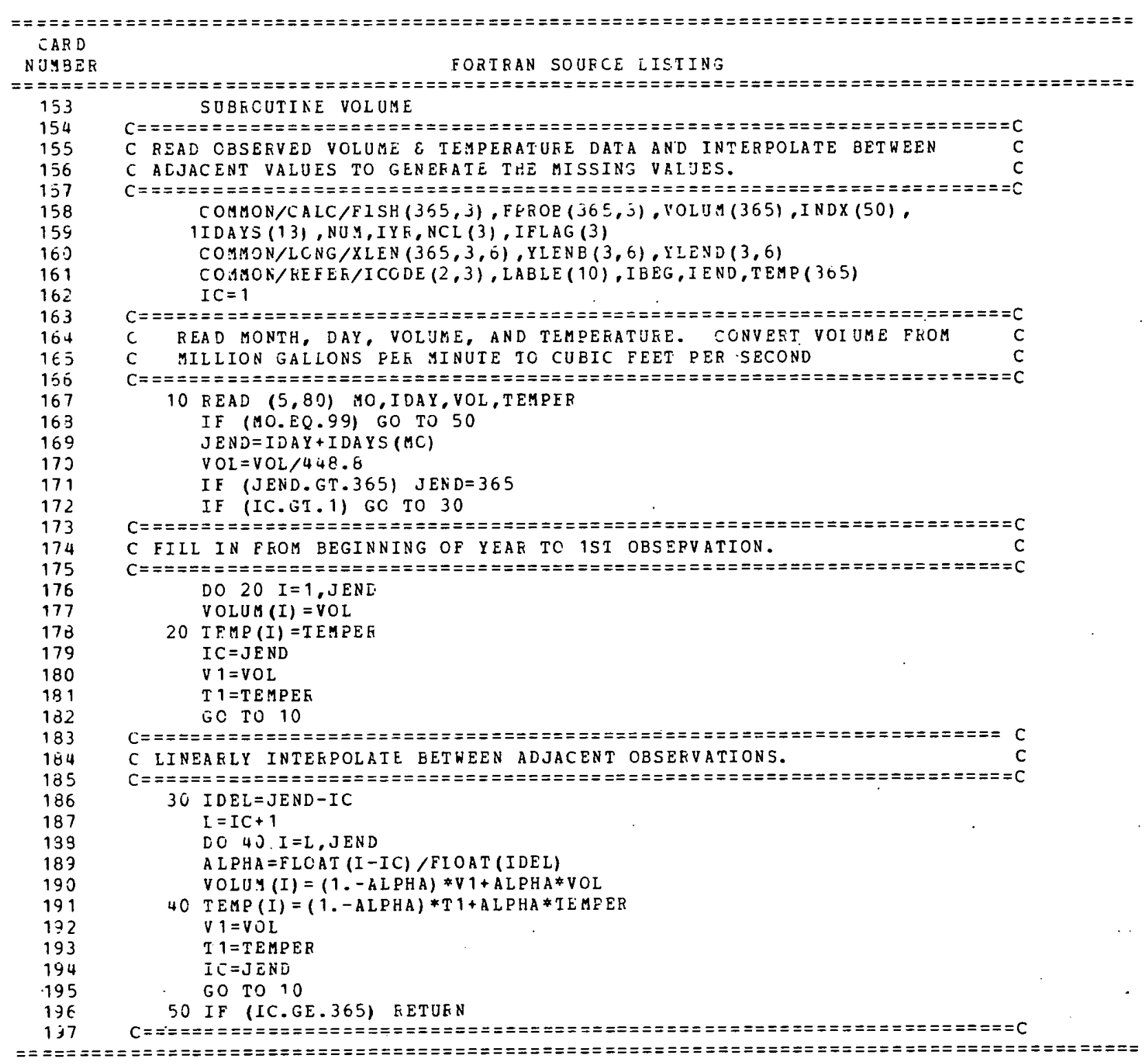


Table 10. Continued

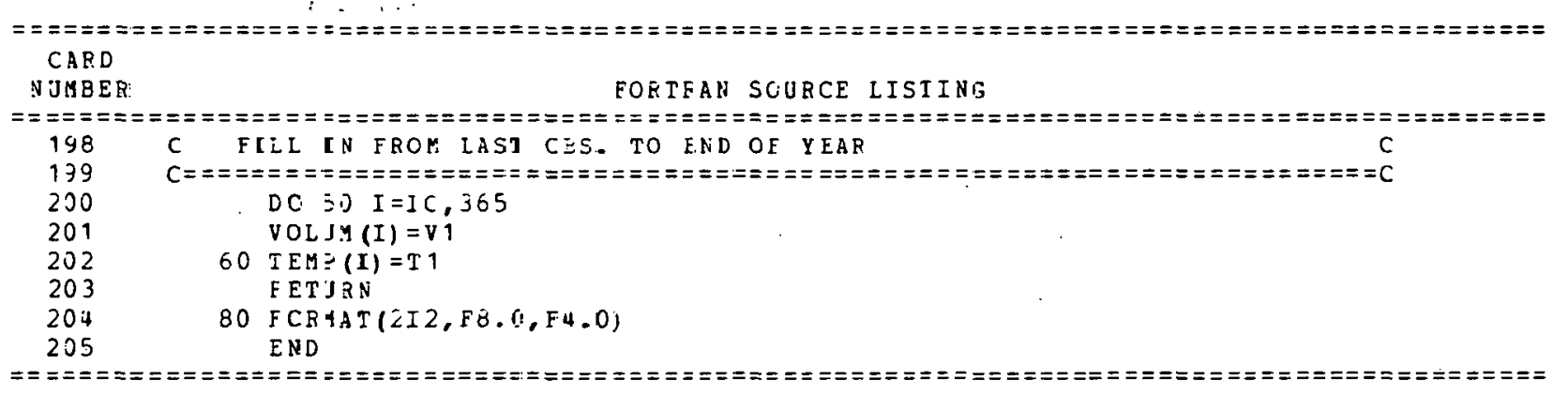


Table 10. Continued

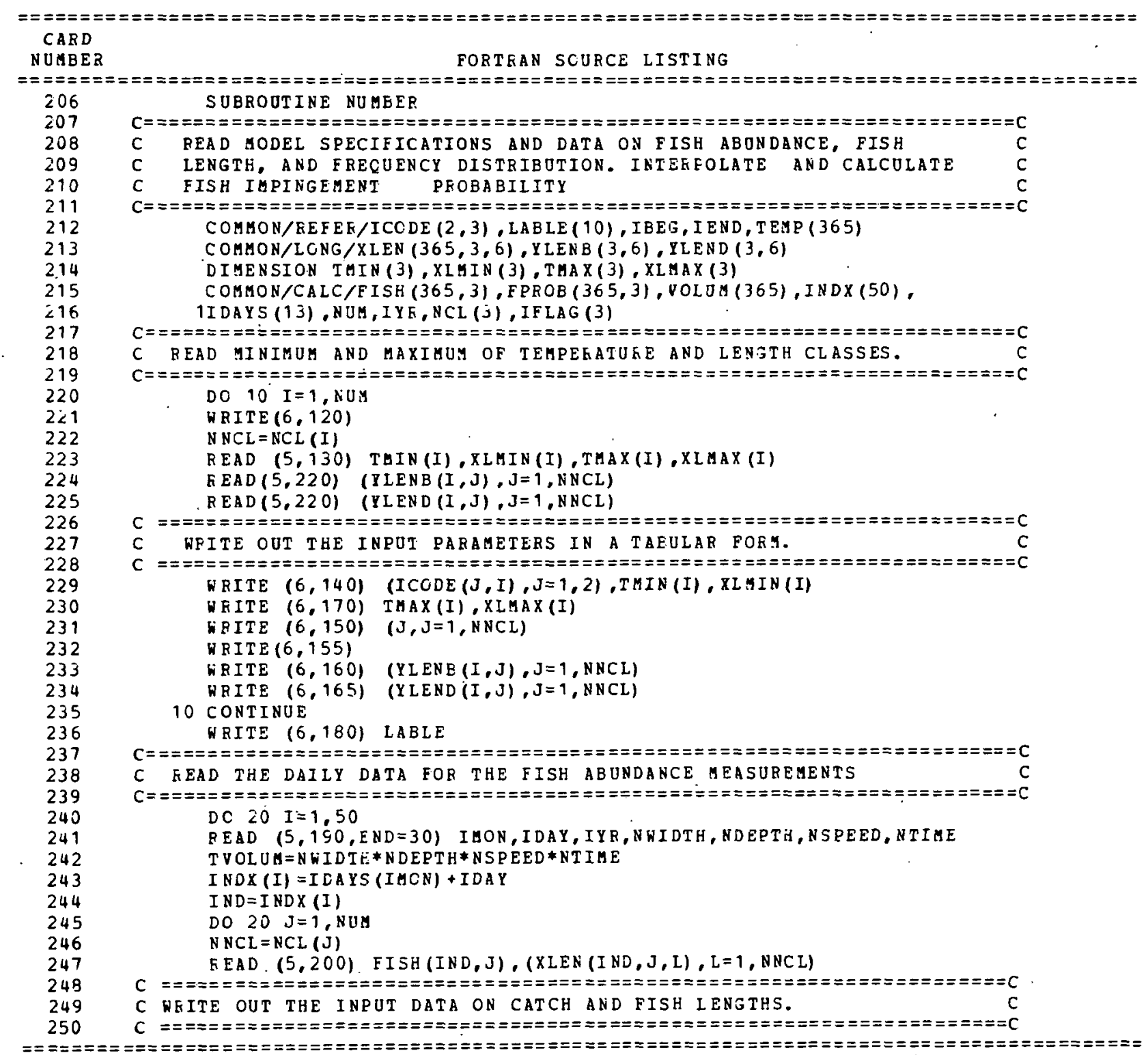




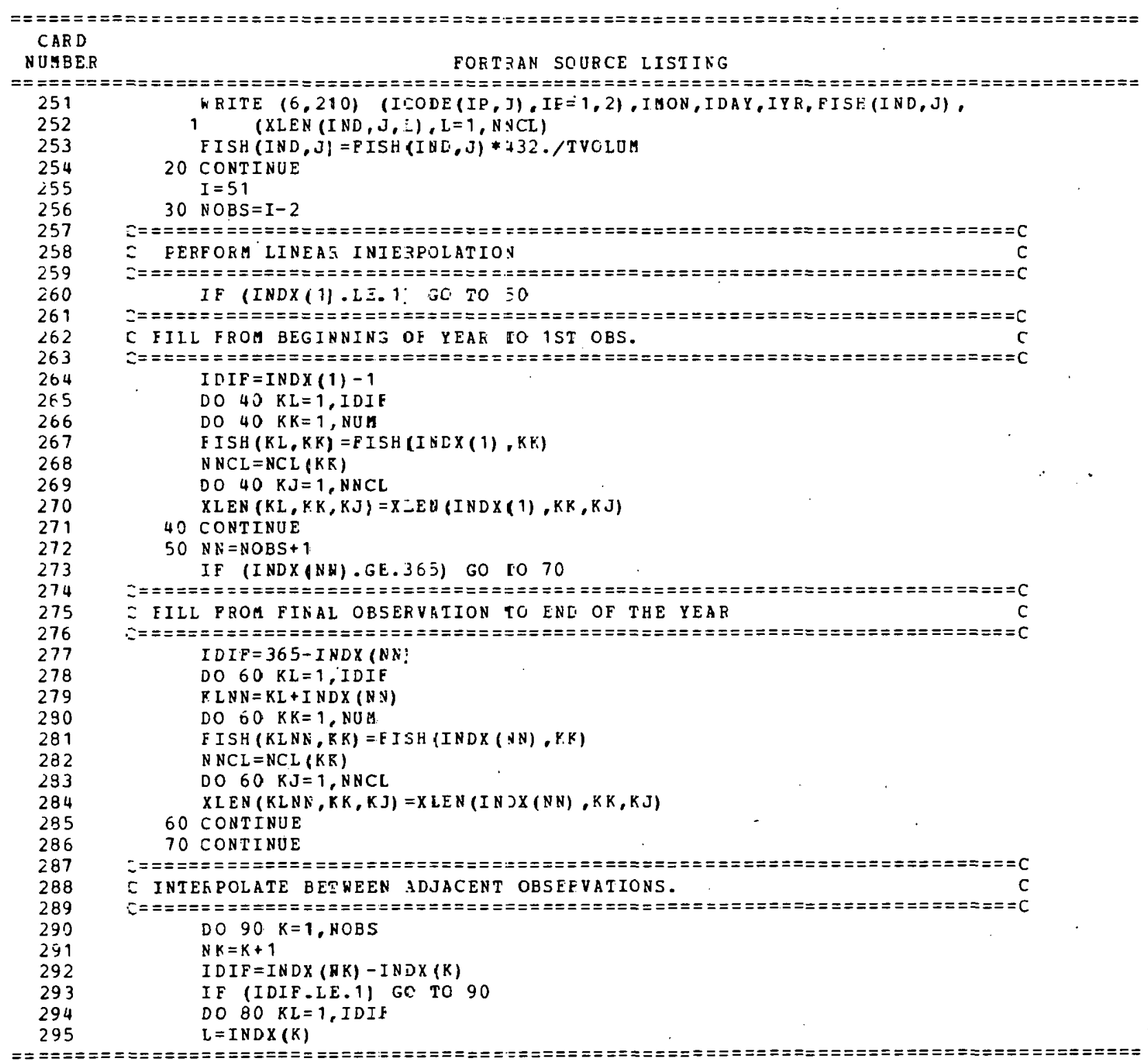




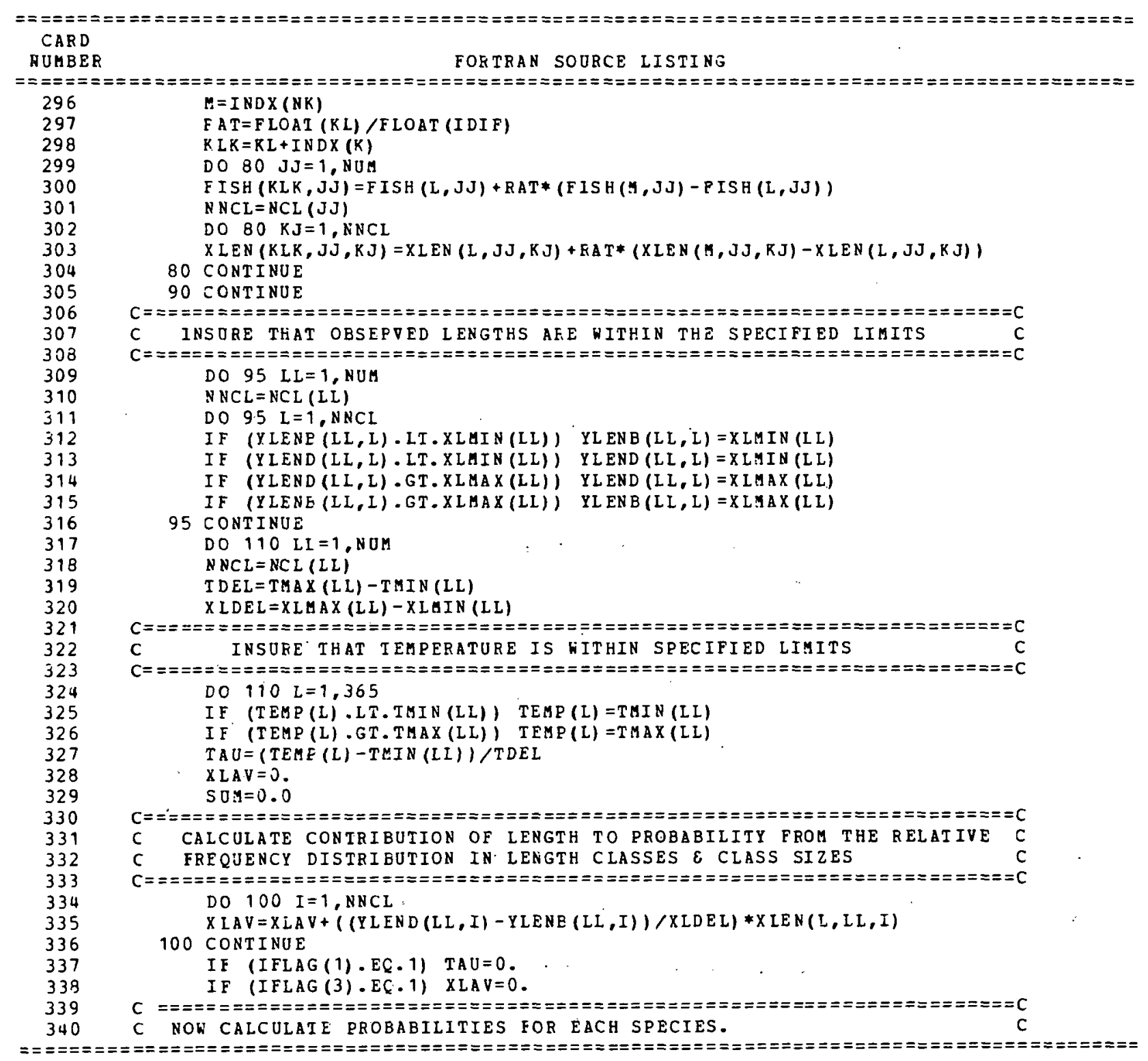


Table 10. Continued




Table 10. Continued

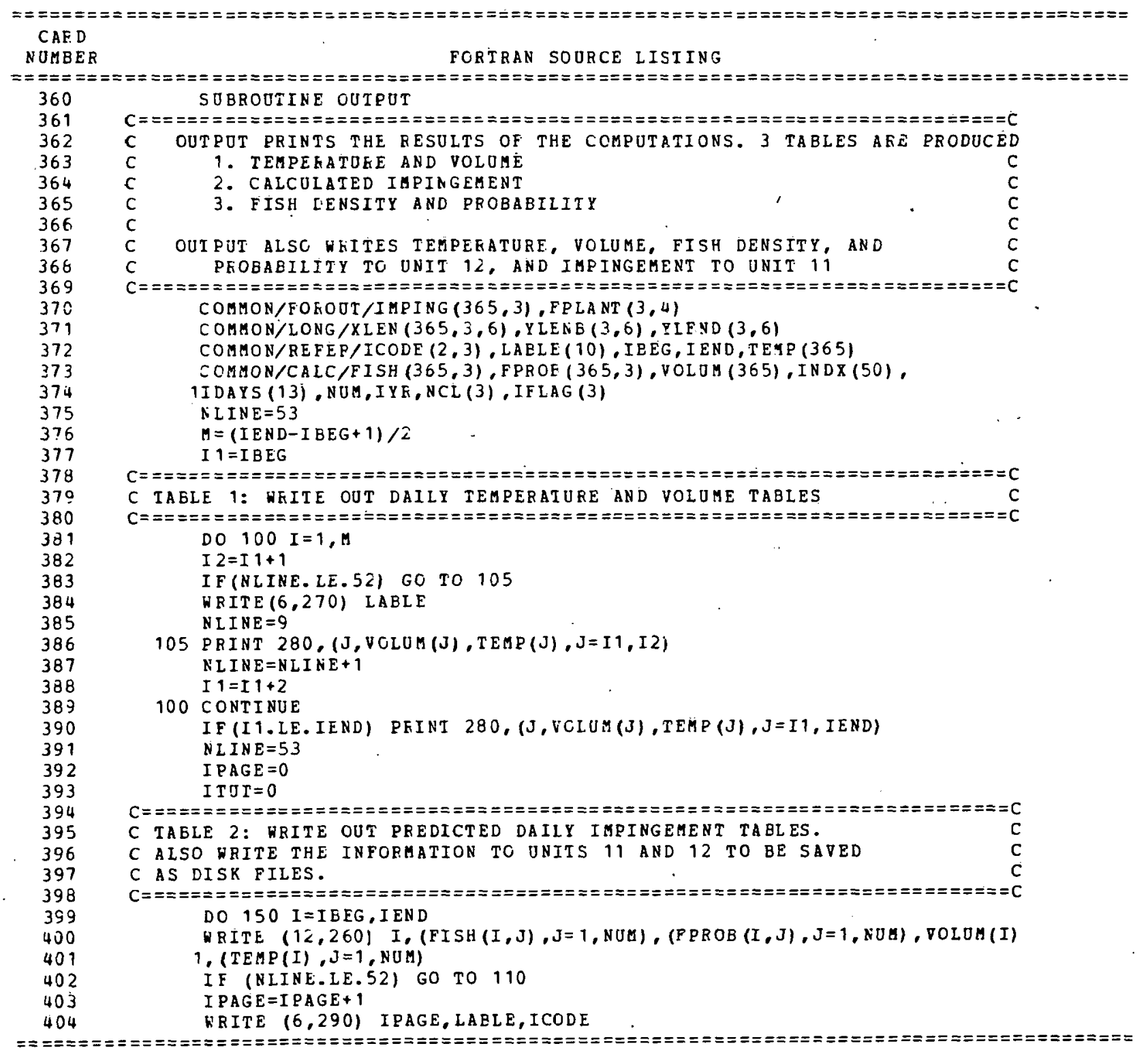




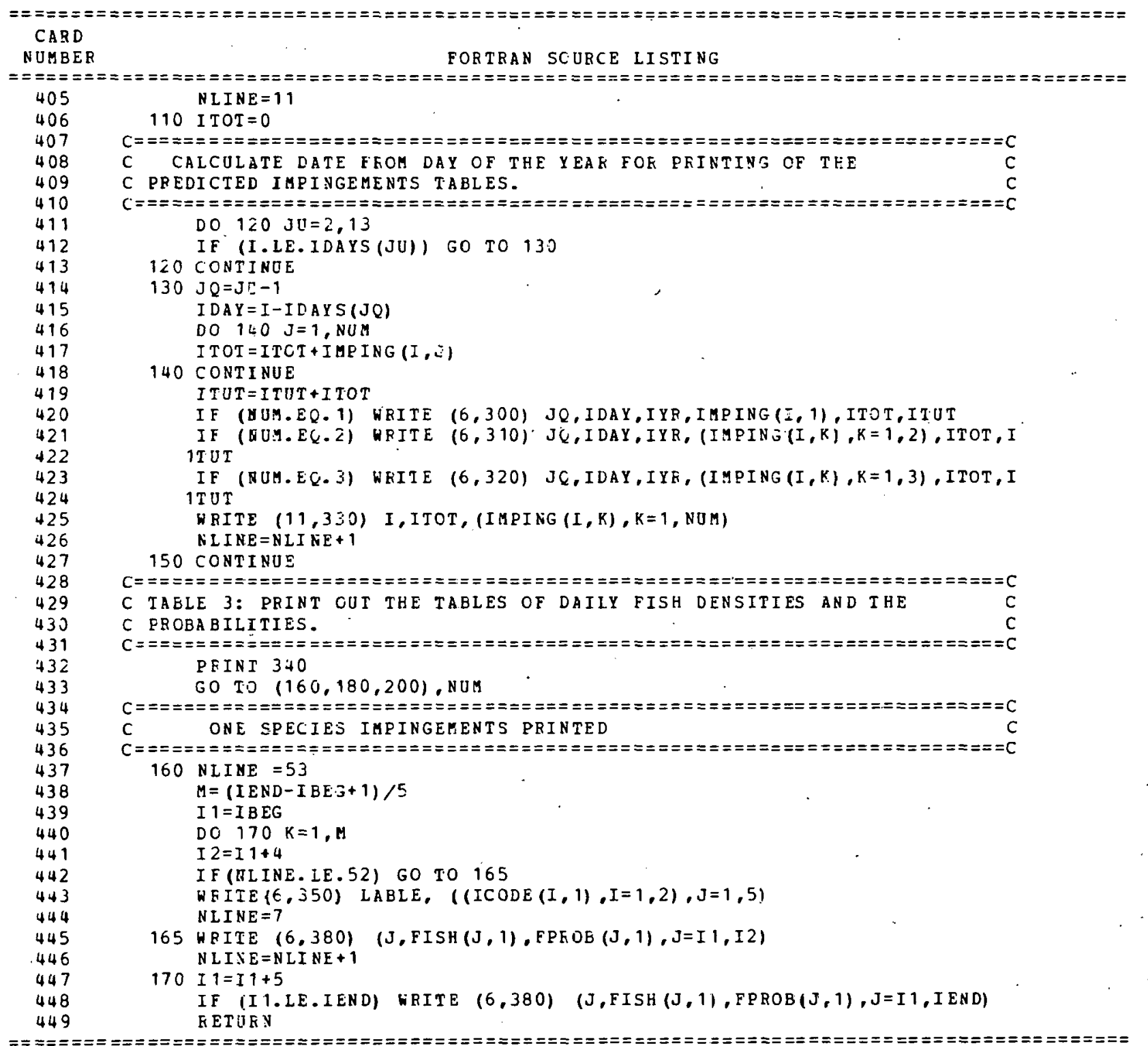


Table 10. Continued

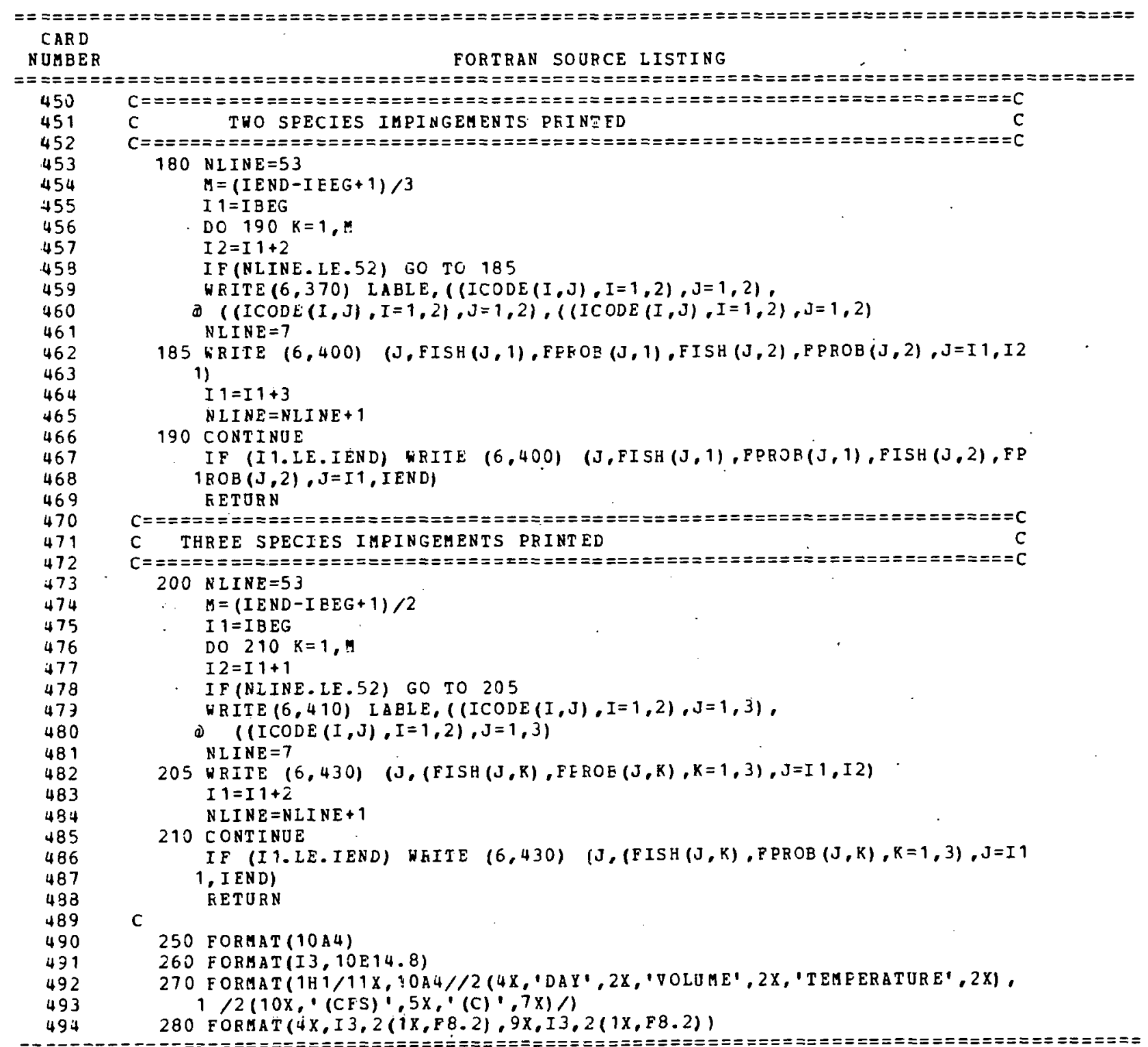


Table 10. Continued

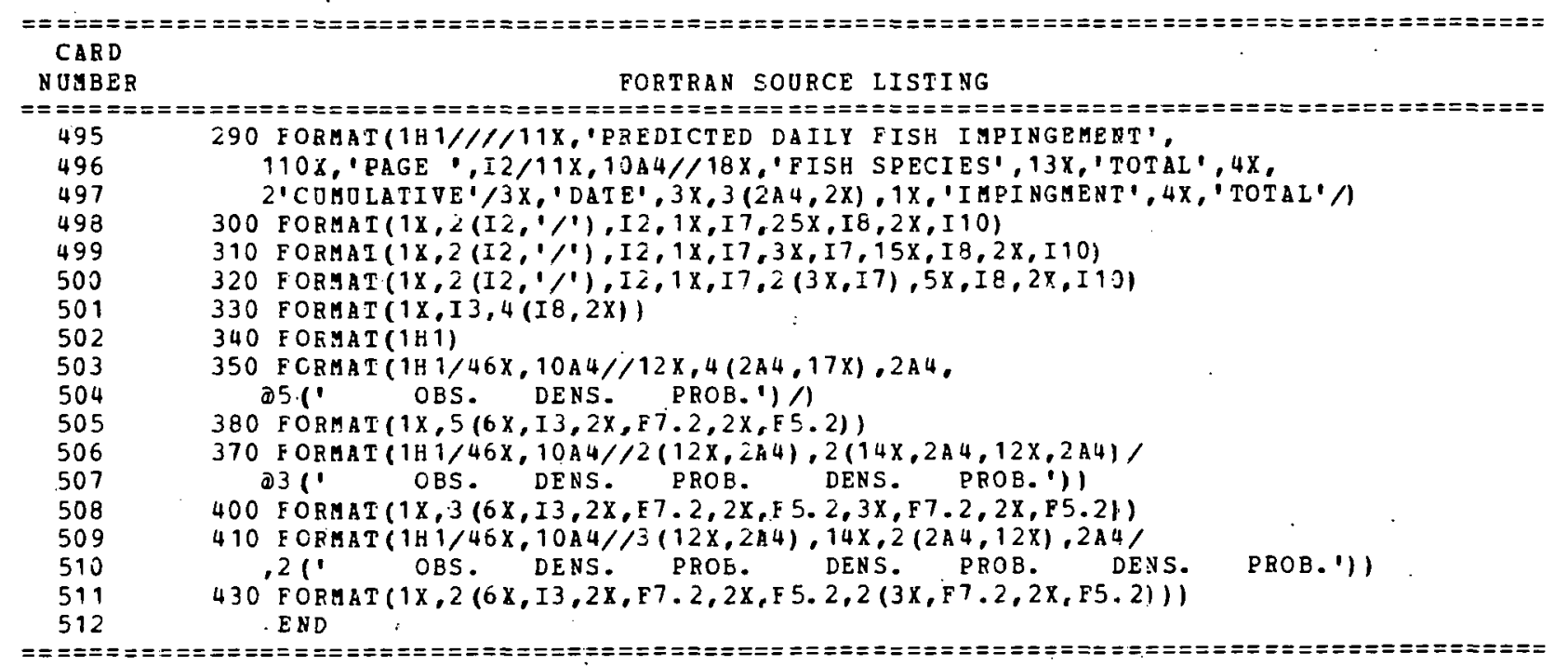


Table 10. Continued

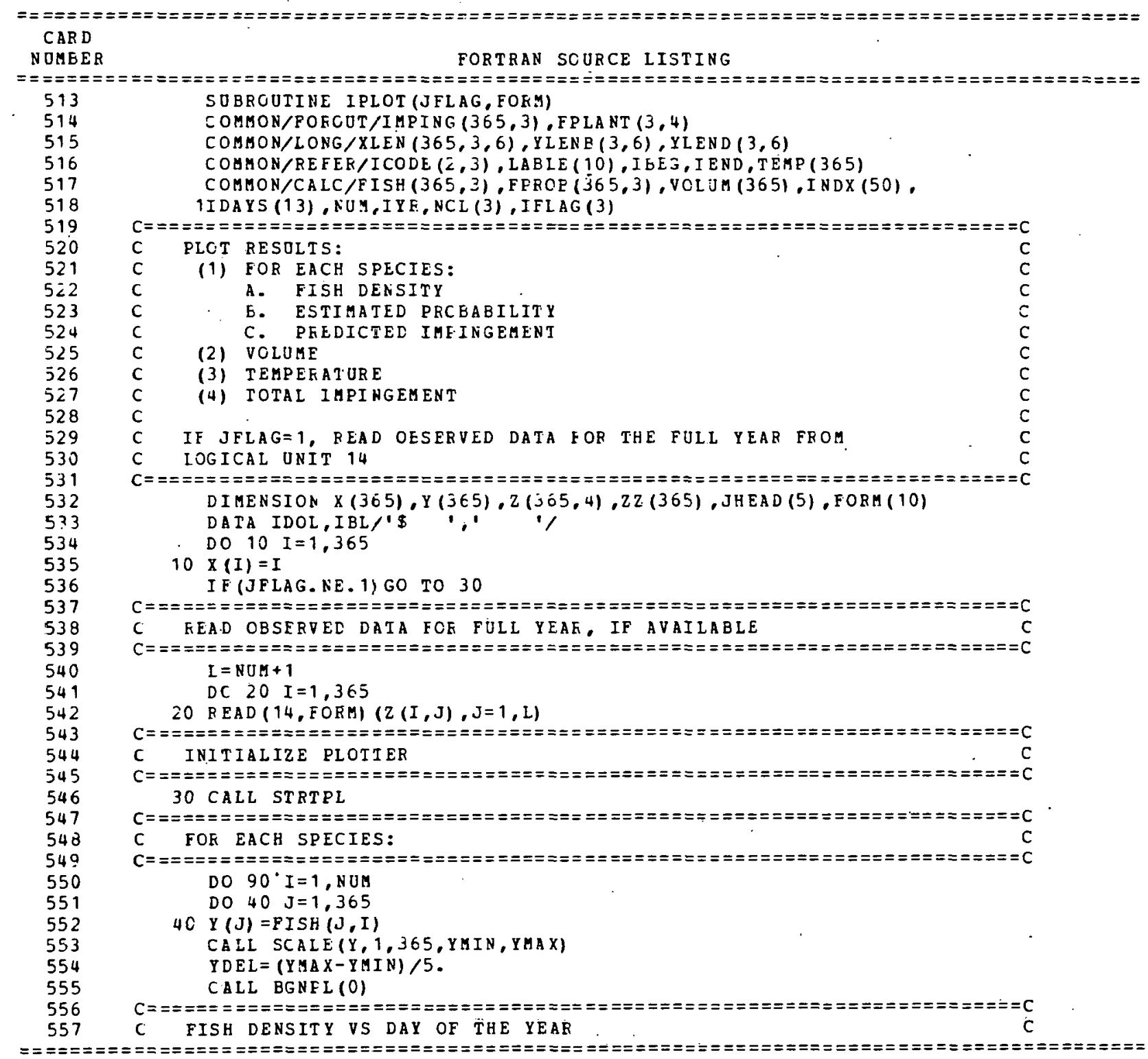




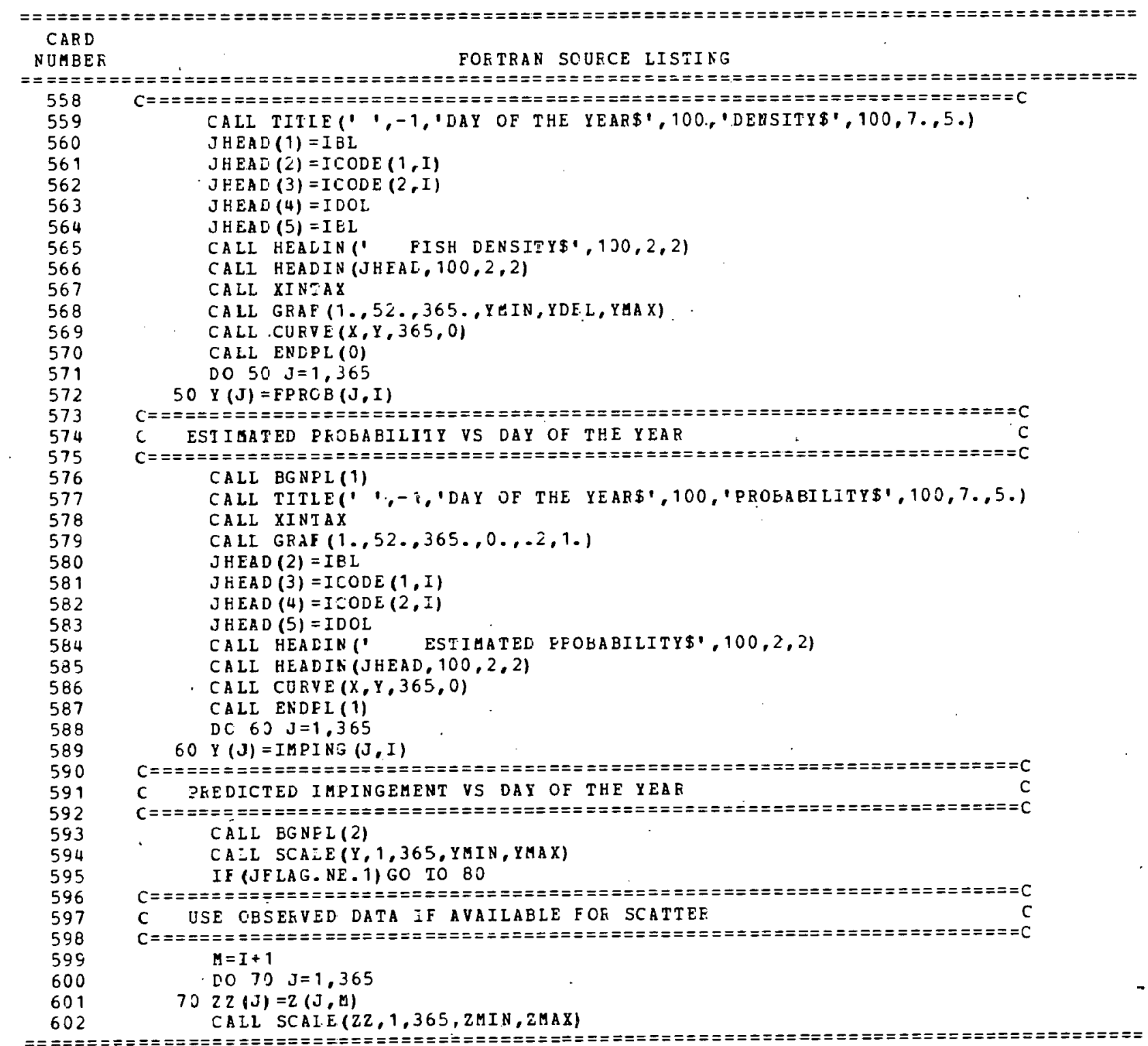


Table 10. Continued

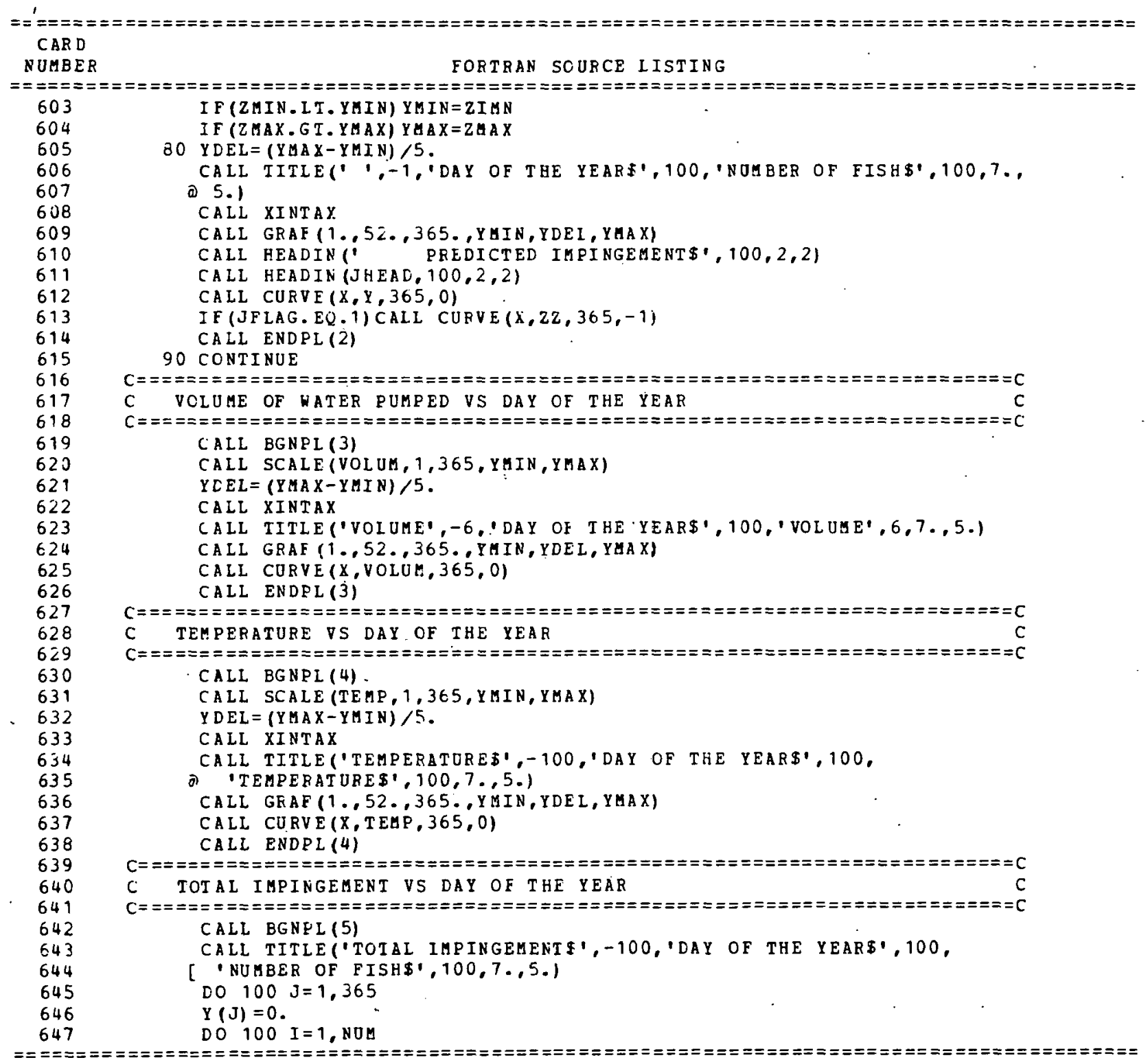




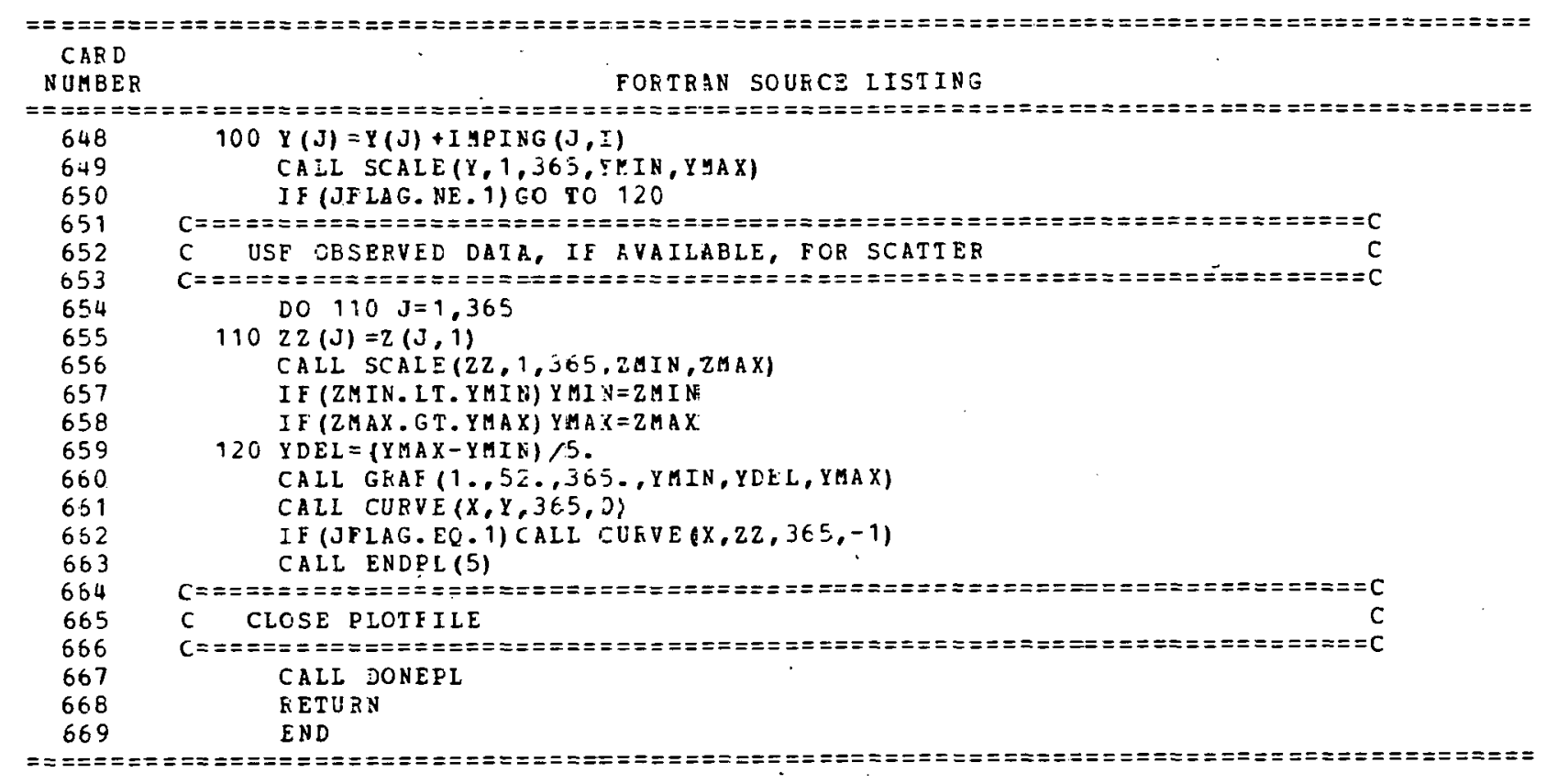




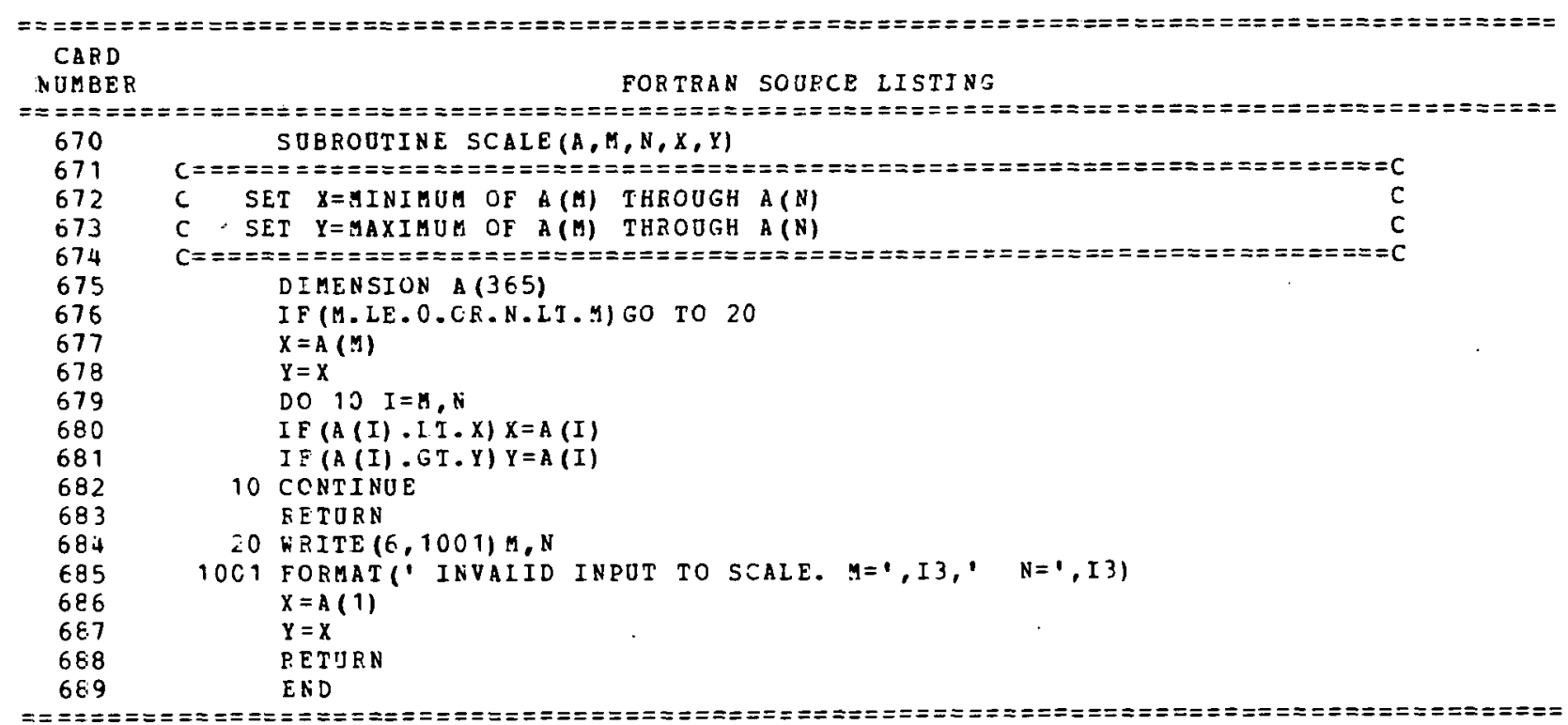




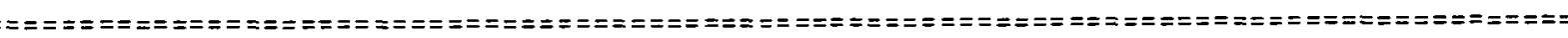
CARD NJMÉER

DATA IISTING

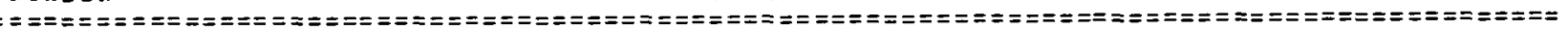

$\begin{array}{ll}690 & \text { BLOC? DATA } \\ 691 & \text { COMBON/FCROUT /IMPING }(365,3), \text { FPLANT }(3,4)\end{array}$

$692 \quad \operatorname{COMBON} / \operatorname{LCNG}, \operatorname{XLEN}(365,3,6), \operatorname{YLENB}(3,6), \operatorname{YLEND}(3,6)$

693 COMBD/REFER/ICOLE (2,3), LAELE (10), IBEG, IEND, TEMP(365)

694 CONHONCALC,FISH (365, 3), FPROE $(365,3)$, VOLUM (365), INDX (50)

695 IIDAYS (13), NUM,IYF,NCL (3), IFIAG (3)

696 DATA IDAY $S / 0,31,59,90,120,151,181,212,243,273,304,334,365 /$

697 DAIA NCL, INJX/53*0/

698 DATA TEMP, VOLUM, FISH, FPROE/ $\angle 920 * 0 . /$

699 DATA IMPIUG/1095*0/

$703 \quad$ END

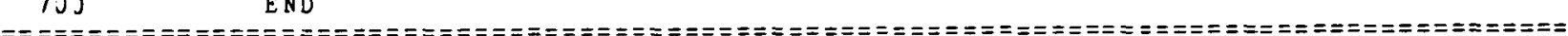


Table 10. Continued

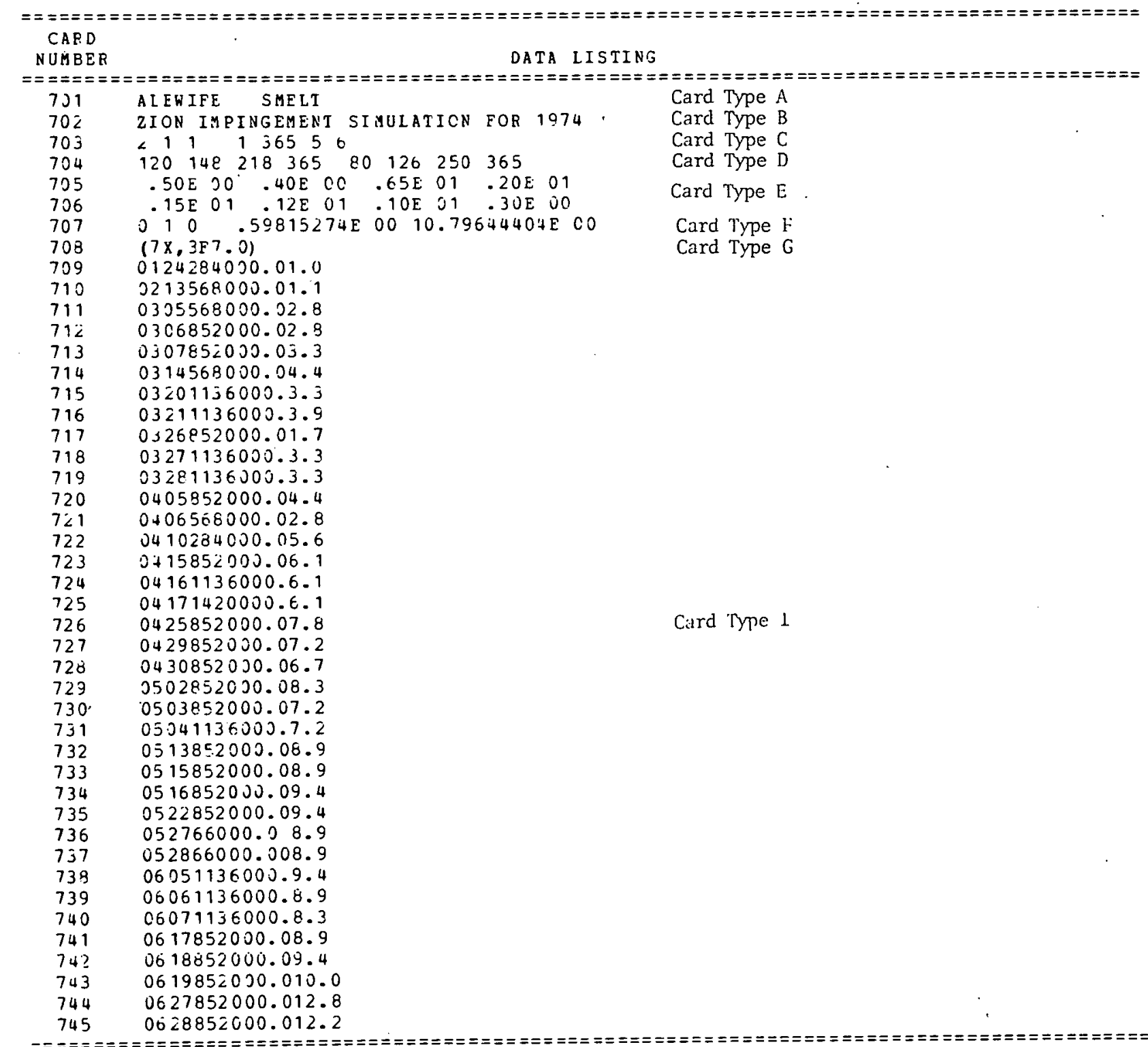


Table 10. Continued

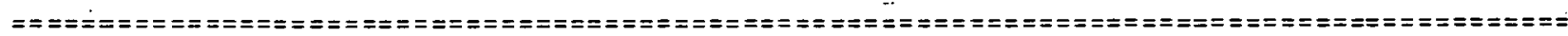
CAR L

NUMBER

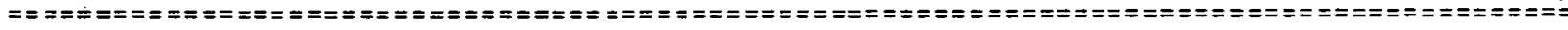

$746 \quad 0703852000.011 .7$

$747 \quad 0709852000.011 .1$

$748 \quad 0715852000.016 .7$

$749 \quad 0716852000.019 .4$

$750 \quad 0717852000.015 .0$

$751 \cdot 0725852000.017 .8$

$752 \quad 0726852000.015 .6$

0905852000.08 .3

08071136001.8 .9

0808852000.012 .8

08091136000.16 .7

08191734000.12 .8

08201136000.11 .1

08211136000.9 .4

09221136000.7 .6

08231420001.15 .0

0829568000.019 .4

09041136000.17 .8

09051420000.17 .8

09261136000.18 .9

09121420000.80

09

09161704000.15 .0

Card Type 1

09171704000.13 .3

09181704000.12 .8

09191704000.13 .9

10031704000.11 .1

1014852000.011 .7

1016852000.011 .1

1) 281704000.10 .0

10281704000.10 .6

10301704000.11 .7

13301704000.11.

11061704000.10 .0

11071420000.9 .4

1108852000.08 .9

11131704000.9 .4

11201704000.7 .8

1205852000.03 .3

1206852000.04 .4

1210852000.02 .8

12111136000.2 .8

12121420000.3

12161704000.2 .2

121717040010.5 .0

12181704000.3 .9

12301704000.4 .4

(1)=" 
Table 10. Continued

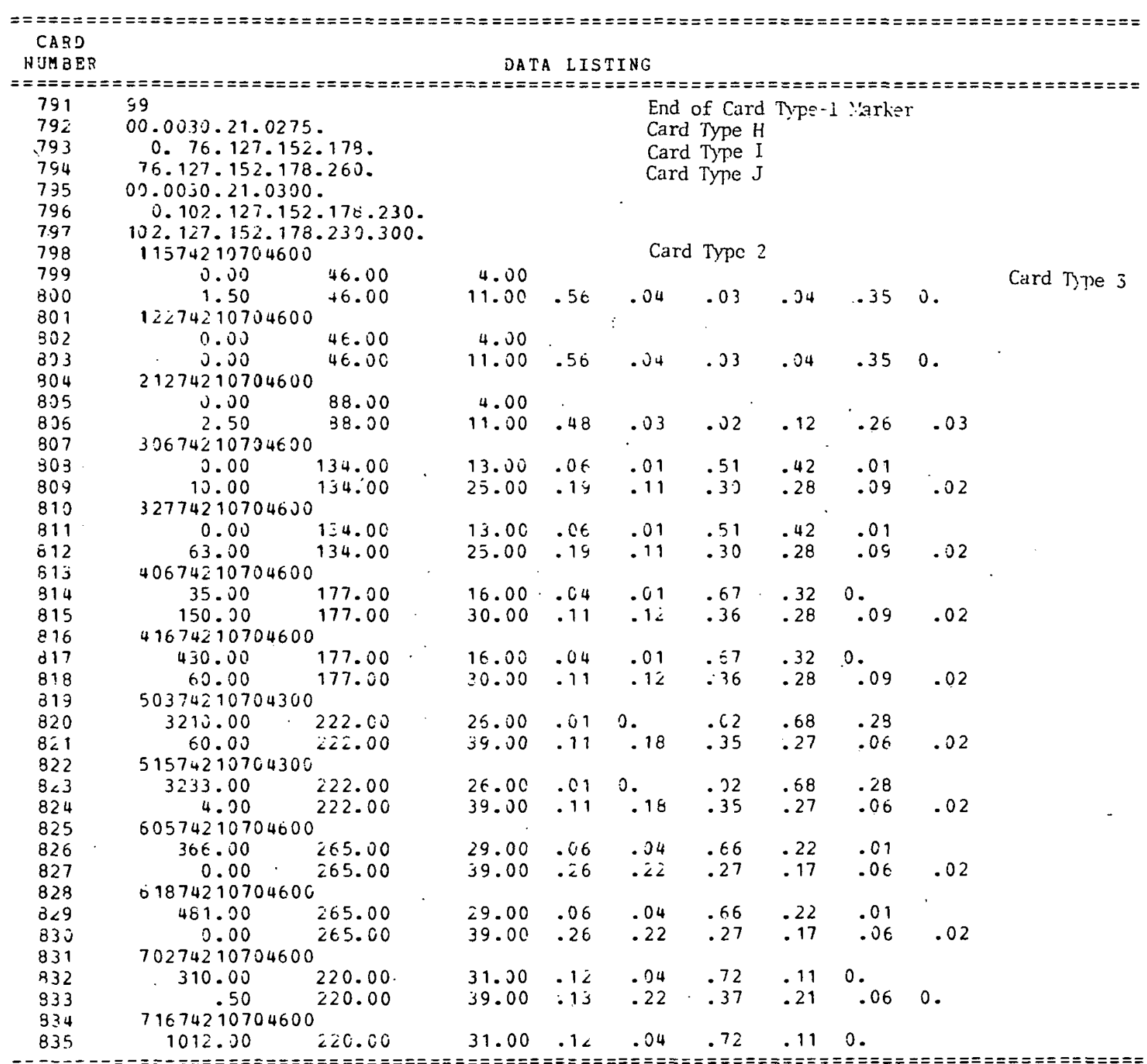


Table 10. Continued

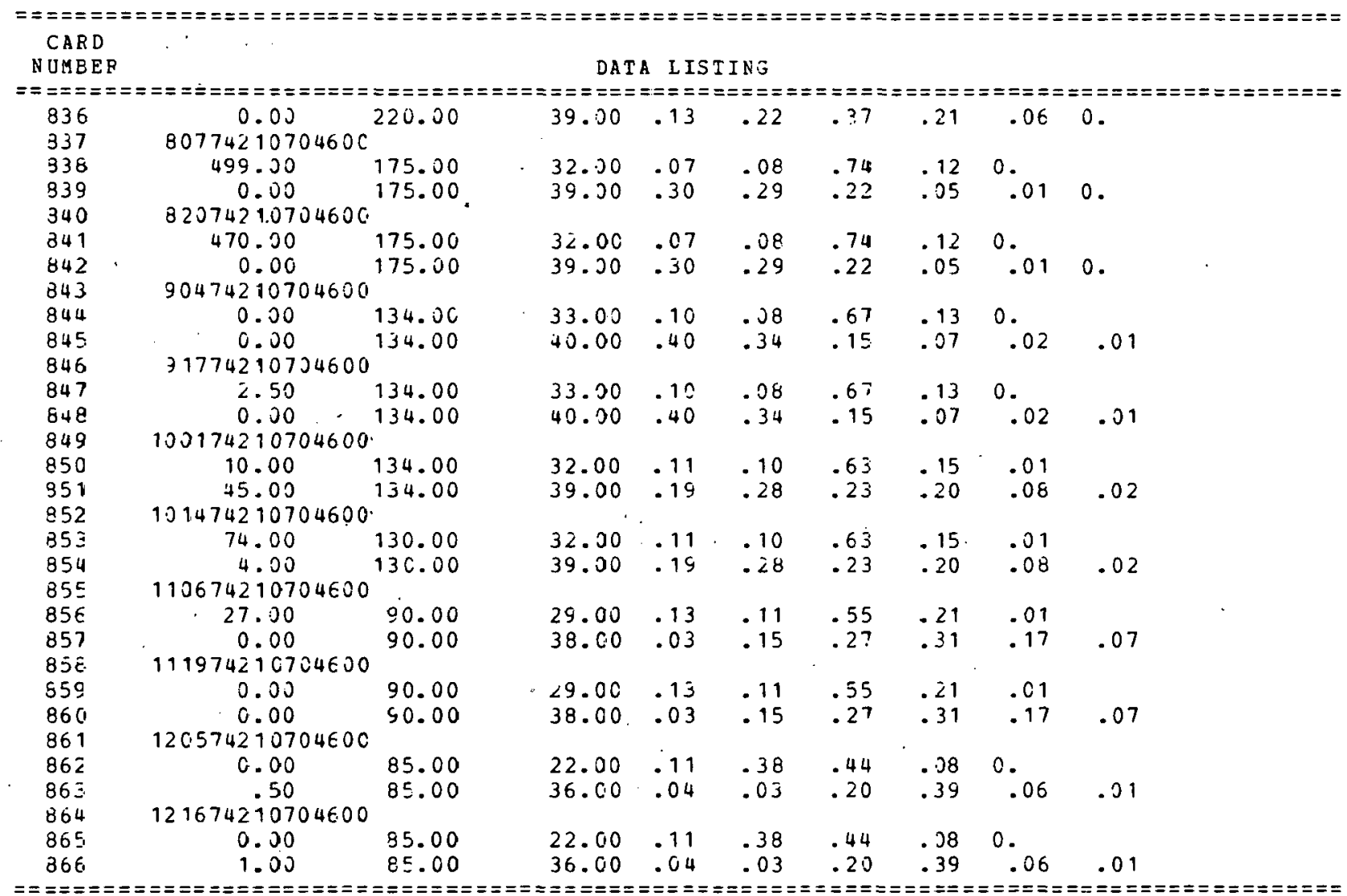




\section{SUMMARY AND CONCLUSIONS}

In this report we have presented the results of the validation of the fish-impingement prediction model developed by Murarka. ${ }^{1}$ Several changes were made in the mathematical form of the model, which reflect new knowledge obtained on the cause and effect relationships of environmental, plant operational, fish behavioral, and abundance variables to fish-impingement rates.

Although the number of variables used in the validation test with Zion Station data were reduced, the performance of the model in calculating daily fish impingements was satisfactory. As a result of sensitivity analyses and an examination of the different functional parts of the model, it was found that fish-density measurements constitute the most important input for enabling the model to predict fish impingements accurately. The water temperature, with its effect on determining the impingement risk to fish, is probably the most important environmental variable considered in the model; water-volume pumped seems to have a moderate effect on the model's predictive capacity.

Several important conclusions can be drawn from this model-validation effort:

1) Information on fish density and abundance is the most important variable in the calculation of fish-impingement rates. Therefore, we conclude that frequent determinations of fish density should be made--perhaps as often as every three or four days or at least at weekly intervals.

2) Data base information should be developed on additional environmental and fish behavioral variables and their functional relationships in the form of the impingement risks.

3) The present mathematical model is adequate in view of the very gross information available on fish factors relating to impingement. Further refinement of the model is not necessary until more quantitative data on the processes relating to fish abundance and impingement rate are developed. 
Finally, the authors also feel that the impingement model may be used in conjunction with some kind of fishery-resource utilization model so that the "end use" of the modeling effort is objectively oriented towards finding the quantitative significance of fish impingement to the fisheries existent in the water body. 


\section{ACKNOWLEDGMENTS}

The authors acknowledge with gratitude the support of the Office of Nuclear Regulatory Research, U. S. Nuclear Regulatory Commission, in financing this project. We particularly appreciate the assistance of Dr: Frank Swanberg, Technical Leader, U. S. Nuclear Regulatory Commission. We are also indebted to Mr. Timothy J. Beissel, ANL, for his painstaking work in modifying and completing the computer software system in its final form.

We express our thanks to Dr. Philip F. Gustafson and Mr. William J. Hallett, of the Division of Environmental Impact Studies, ANL, for their encouragement during the course of this work. And special thanks are also due Mr. John Martens for editing this report. 


\section{REFERENCES}

1. Murarka, I. P. 1977. A Model for Predicting Fish Impingement at Cooling Water Intakes. Report ANL/AA-8, Argonne National Laboratory. Available from the National Technical Information Service, Springfield, Va. 22161. $\$ 4.50$.

2. Industrial BIO-TEST Laboratories, Inc. 1974. Operational environmental monitoring in Lake Michigan near zion Station, January 1974 through June 1974, Volume III, Semi-annual Report to Commonwealth Edison Company, Chicago, I11.

3. Industrial BIO-TEST Laboratories, Inc. 1975. Operational environmental monitoring in Lake Michigan near Zion Station, July 1974 through December 1974, Volume I and II, Semi-annual Report to Commonwealth Edison Company, Chicago, I11.

4. CDM/Limnetics. 1977. The lake-wide effects of impingement and entrainment on the Lake Michigan fish populations, Report to Commonwealth Edison Company, Consumers Power Company, Indiana and M1chtyan Puwer, Nurthern Indiana Public Service Company, Wisconsin Electric Power Company, Wisconsin Power and Light and Wisconsin Public Service Corporation. February, 1977.

5. Becker, G. C. 1976. Environmental status of the Lake Michigan region, Vol. 17, Inland fishes of the Lake Michigan Drainage Basin, Report ANL/ES-40, v. 17. Argonne National Laboratory, Argonne, I11. 237 pp.

6. CDM/Limnetics. 1976. Review of the literature on Lake Michigan fish, Report to Commonwealth Edison Company, Consumer Power Company, Indiana and Michigan Power, Northern Indiana Public Service Company, Wisconsin Electric Power Company, Wisconsin Power and Light and Wisconsin Public Service Corporation. March, 1976. 
7. NALCO Environmental Sciences. 1976. Compilation of reports relating to entrainment and impingement studies at Zion Generating Station, 1976, Volumes I and II, Report to Commonwealth Edison Company, Chicago, III. March, 1976.

8. Colby, P. J. 1973. Response of the alewives, AZosa pseudoharengus; to environmental changes, p. 163-198, In: Responses of Fish to Environmental Changes, Walter Chavin, Ed., Charles C. Thomas, Springfield, Ill.

9. Kothas, E. 1970. Studies of the swimming speed of some anadromous fishes found below Conowingo Dam, Susquehanna River, Maryland, Ichthyological Associates, Ithaca, New York. 19 pp.

10. Wagner, W. C. 1972. Utilization of alewives by inshore piscivorous fishes in Lake Michigan. Trans. Amer. Fish Soc. 101:55-63.

11. Brown, E. H., Jr. 1972. Population biology of alewives, Alosa pseudoharengus, in Lake Michigan, 1949-1970. J. Fish Res. Can. 29:477500 .

12. Romberg, G. P., S. A. Spigarel1i, W. Prepejcha and M. M. Thommes. 1973. Fish behavior at a thermal discharge into Lake Michigan. p. 296-312, In: Thermal Ecology, J. Whitfield Gibbons and R. R. Sharitz, Eds., Technical Information Center, U. S. Atomic Energy Commission, Washington, D. C.

13. Emery, A. R. 1973. Preliminary comparisons of day and night habits of freshwater fish in Ontario lakes. J. Fish Res. Bd. Can. 30:761-774.

14. Richkus, W. A. 1975. Migratory behavior and growth of juvenile anadromous AZosa.pseudoharengus in a Rhode Island drainage. Trans. Amer. Fish Soc. 104:483-493.

15. Richkus, W. A. 1975. The response of juvenile alewives to water currents in an experimental chamber. Trans. Amer. Fish Soc. 104:494-498. 
16. Industrial BIO-TEST Laboratories, Inc. 1975. Evaluation of thermal. effects in southwestern Lake Michigan, species studies 1972-1973. Report to Commonwealth Edison Company, Chicago, I11. January, 1975.

17. Burbidge, R. G. 1969. Age, growth, length-weight relationship, sex ratios and food habits of American smelt, Osmerus mordax, from Gull Lake, Michigan. Trans. Amer. Fish Soc. 98:631-640. 